\title{
I-10035-0562
}

BJC/OR-2345/R3

ENVIRONMENTAL MANACEBENT

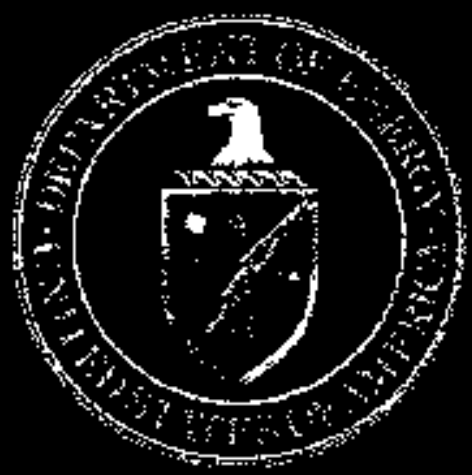

BECHTEL JACOBS COMPANY LLC OAK RIDGE ENVIRONMENTAL MANAGEMENT GLEANUP CONTRACT WITH THE UNITED STATES DEPARTIAET OF ENERGY
Engineering Evaluation Report on K-311-1 Floor Subsidence (2008 Annual Report) at the East Tennessee Technology Park Oak Ridge, Tennessee
This document is approved for public release per review by Art MeBnde
RECEIVED DEC 112008 $11 / 12 / 08$. 


\section{Engineering Evaluation Report on \\ K-311-1 Floor Subsidence (2008 Annual Report) at the East Tennessee Technology Park Oak Ridge, Tennessee}

Date Issued-November 2008

Prepared for the

U.S. Department of Encrgy

Office of Environmentsl Management

BECHTEL JACOBS COMPANY LLC

managing the

Envirotimental Management Activitjes at the

East Tennessee Tecbnology Park

Y-12 National Security Complex Oak Ridge National Laboratory

under contract DE-AC05-980R22700

for the

U.S. DEPARTMENT OF ENERGY 


\section{APPROVALS}

\section{Engineering Evaluation Report on \\ K-311-1 Floor Subsidence \\ (2008 Aunual Report) at the \\ East Tennessee Technology Park \\ Oak Ridge, Tennessee}

BJC/OR-2345/R3

November 2008

\section{Prepared by:}

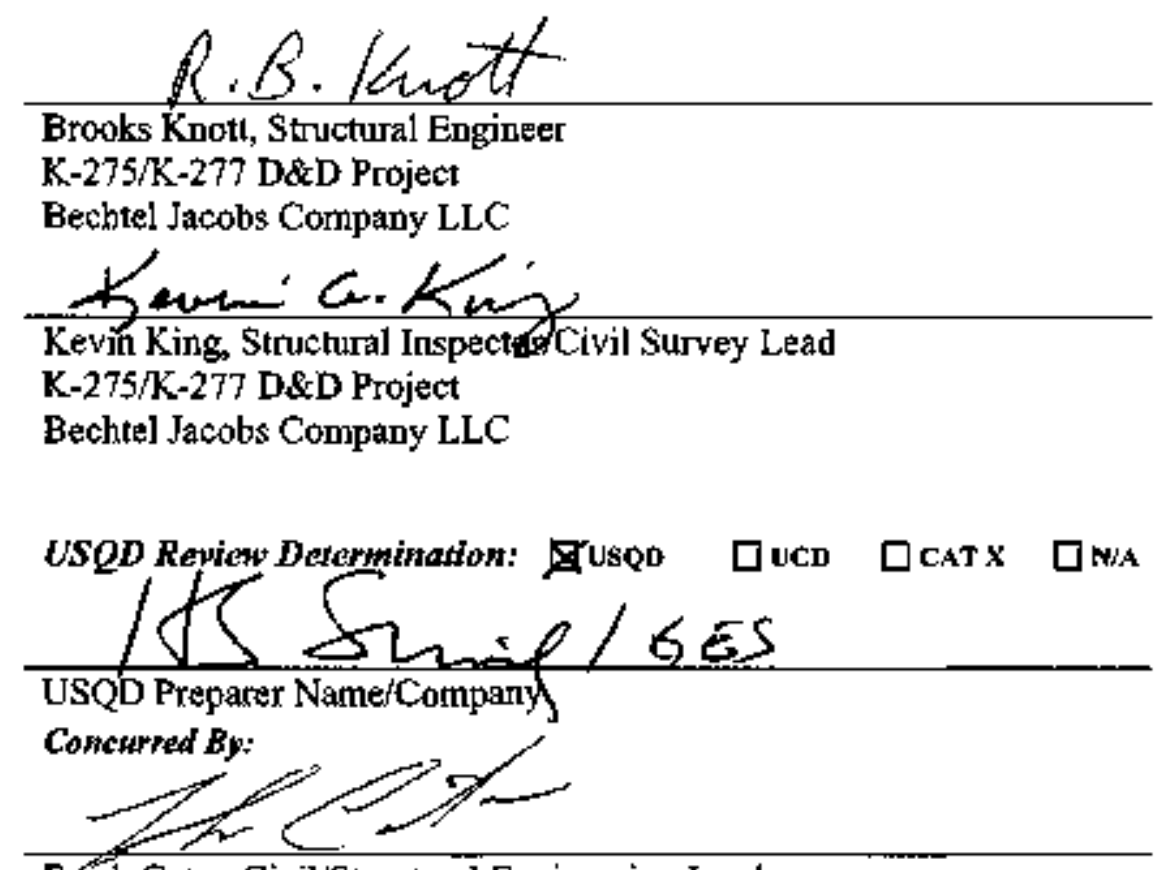

Frăk Cater, Civil'Structural Engineering Lead

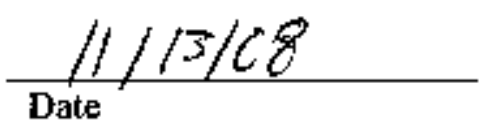

Brooks Knotı, Structural Engineer

Date

Bechtel Jacobs Company LLC

K-275/K-277 D\&D Project

Bechtel Jacobs Company LLC

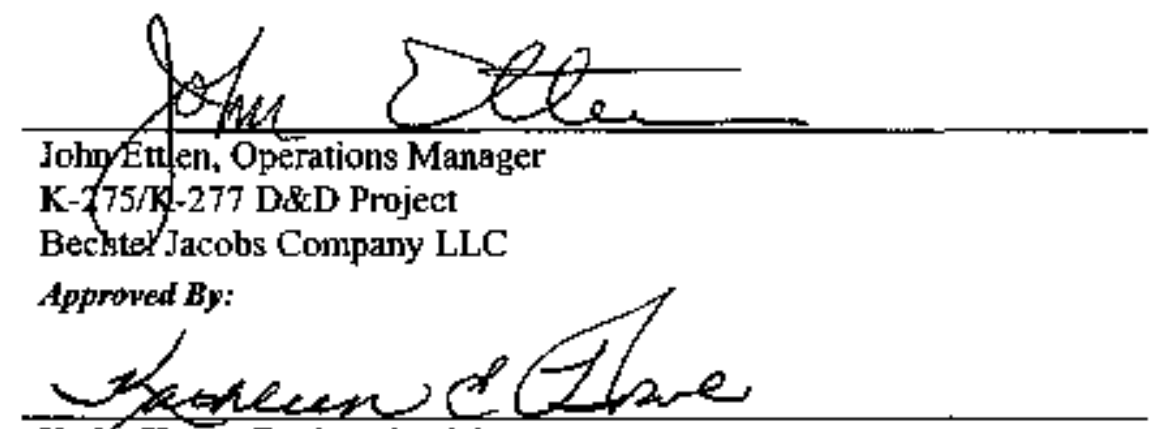

Katly Howe, Engineering Manager

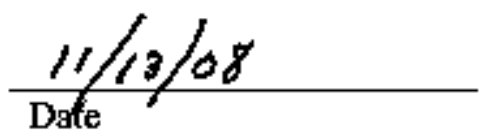

K-275/K-277 D\&D Project

Bechtel Jacobs Company LLC 


\section{CONTENTS}

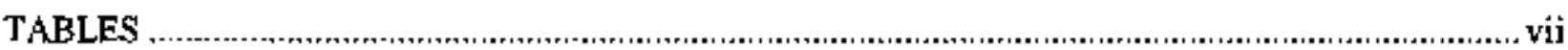

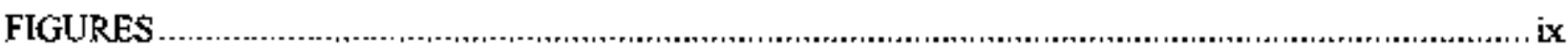

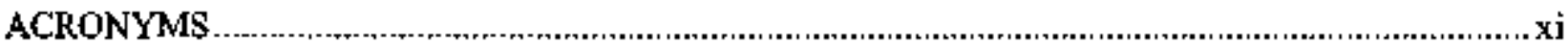

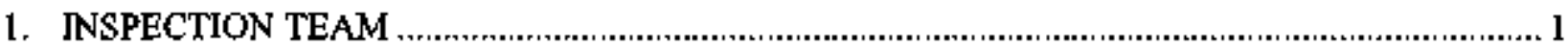

2. SUMMARY

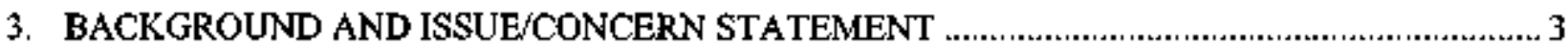

4. ASSUMPTIONS

5. EVALUATION

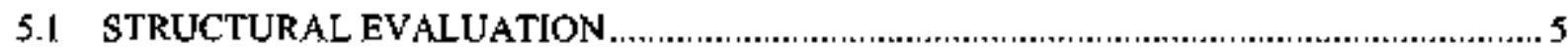

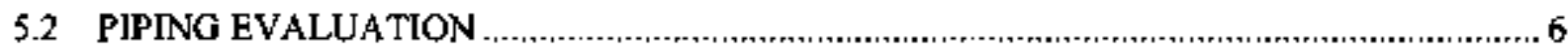

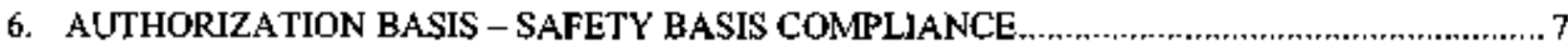

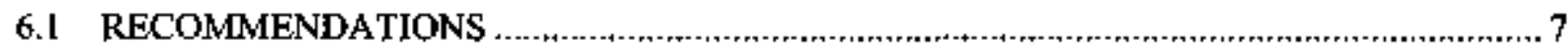

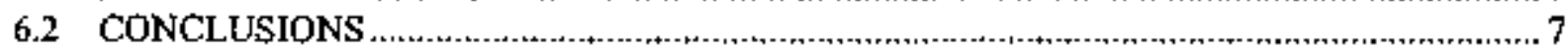

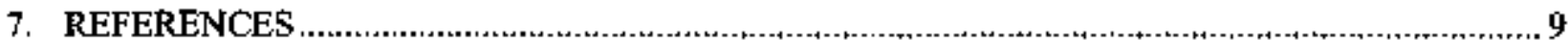

APPENDIX A. TABLE OF SETTLEMENT ELEVATIONS (FROM ATJ REPORT) AND 2006 REPORT K-311-1 FLOOR SUBSIDENCE SURVEY AREA SKETCH (FROM ATI REPORT), AND

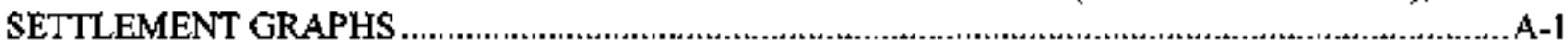

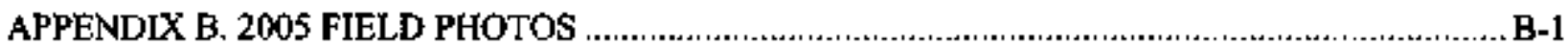

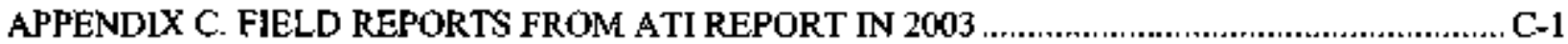




\section{TABLES}

Table A-1. Elevations in K-3Ll-l (former Booster Station)* A-3 


\section{FIGURES}

Fig. A-1. K-311-1 floor subsidence survey area reference sketch, ..................................................A-4

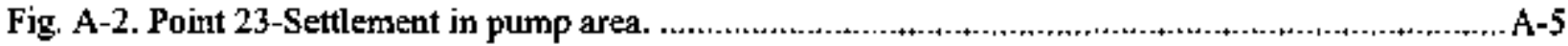

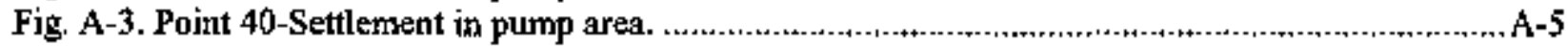

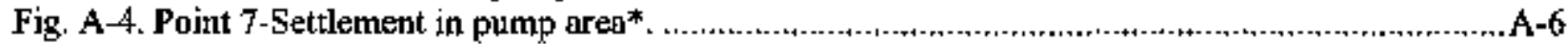

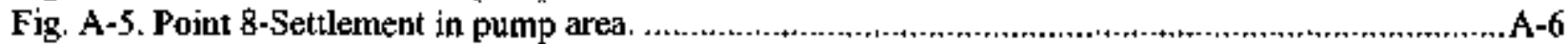

Fig. A-6. Point 9-Settlement in pump area. ...................................................................................

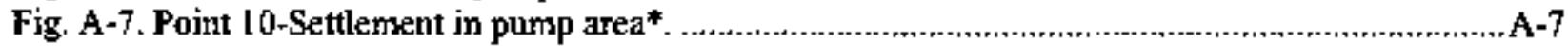

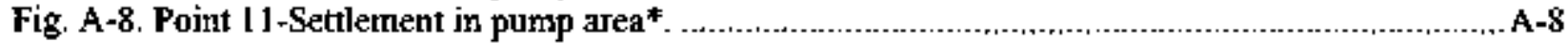

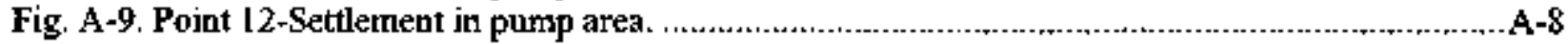

Fig. A-10. Point 15-Settlement in pump area. .......................................................................

Fig. A-1 l. Point 16-Settlement in pump area .......................................................................

Fig. A-12. Point 18-Settlement in pump area. ......................................................................

Fig. A-13. Point 19-Settlement in pump area. ....................................................................... A-10

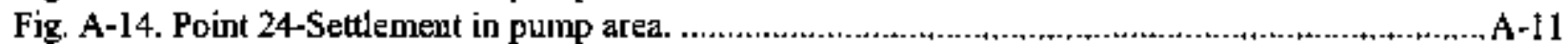

Fig. A-15. Point 26-Settlement in pump area. ....................................................................... 1

Fig. A-16. Point 27-Settlement in pump area. .................................................................

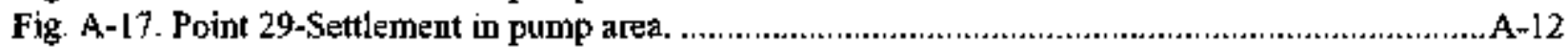

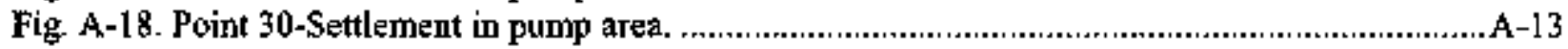

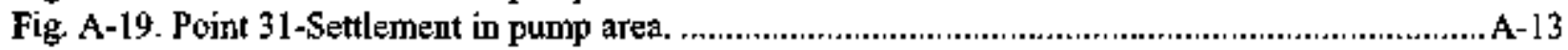

Fig. A-20. Point 32-Settlement at gradc bcam* ................................................................ 4

Fig. A-21. Point 3-Settlement at grade beam* .........................................................................

Fig. A-22. Point 17 -Settlement at grade beam* .....................................................................15

Fig. B-1. Photo of settlement under exterior wall grade beam. ............................................................. B-3

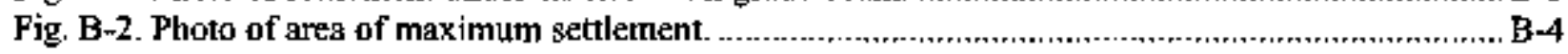

Fig. B-3. Photo of ares of maximum settlement.

Fig. B-4. Photo of settlement under pipe supports ................................................................ 6

Fig. B-5. Photo of area of floor slab separation. ......................................................................

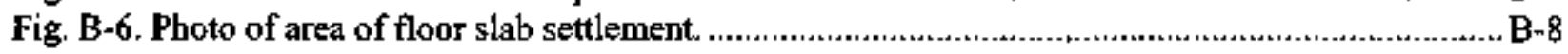

Fig. B-7. Photo of area of floor slab settlement. .................................................................... B-9

Fig. B-8. Photo of example of settlement crack in floor slab. .................................................... B-10

Fig. B-9. Photo of area of floor slab separation. ................................................................... B-11

Fig. B-10. Photo of example of floor slab crack. ...................................................................... B

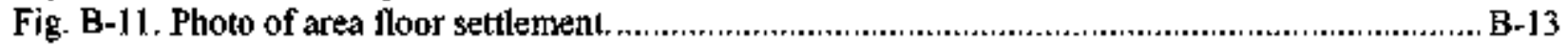

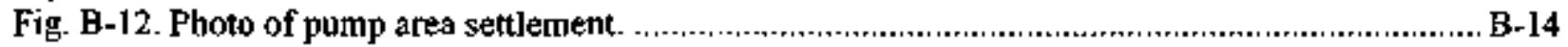

Fig. B-13. Photo of settlement at "A" pump area .......................................................................

Fig. B-14. Photo of floot settlement at "A" pump area .................................................................. B-16

Fig. B-15. Photo of floot settlement at "B" pump arca. ................................................................. B-17

Fig. B-16. Photo of floot settlement at grade beam. ..................................................................... B-18

Fig. B-17. Photo of floor settlement under pipe supporl. .................................................................... B-I9

Fig. B-18. Photo of pump "A" area floor settlement ........................................................................

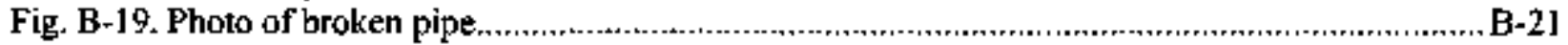

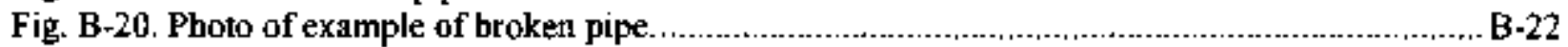

Fig. B-21. Photo of defonmed 90-degree connections. .............................................................. B-23

Fig. B-22. Photo of floor settlement below cooler.................................................................... B-24

Fig. B-23. Photo of example of broken pipe support................................................................

Fig. B-24. Photo of broken pipe support............................................................................. B-26

Fig. B-25. Photo of gas cooler area. 
Fig. B-26. Photo of elongated expansion joints.............................................................................

Fig. C-1. View of north edge of damaged stab showing extent of subsidence (looking northwest)*..... C-3

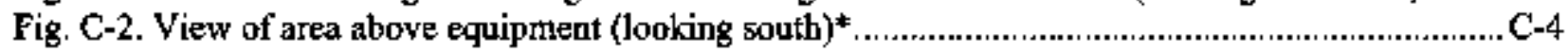

Fig. C-3. View of damaged slab and equipment (looking south)* ...............................................

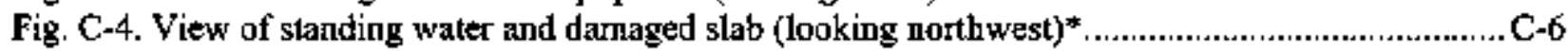




\section{ACRONYMS}

BJC

ETTP

Bechtel Jacobs Company LLC

SSC

East Tennessee Technology Park

Structures, Systems and Components 


\section{INSPECTION TEAM}

The Inspection Team for this project included the followng:

- K. A. King-\$tructural Engmeer

- S. J. Baket -Struclural Inspector

\section{SUMMARY}

The purpose of this task is to evaluate the effect of floor settlement on bulding structure, piping, and equipment foundations between column lmes 1 and 2 and $B$ and $K$ of Bldg. K-31l-1 (see Fig. A-1 in Appendix A) at East Tennessee Technology Park (ETTP), Oak Ridge, Tennessee. Revision 0 of this document covers the 2005 annual inspection. Revision 1 addresses the 2006 annual inspection, Revision 2 addresses the 2007 annual inspection, and Revision 3 covers the 2008 annual inspection, as indicated by the changed report title. A cuvl survey and visual inspection were performed. Only a representatuve number of pounts were measured dunng the 2008 survey. The exact location of a number of survey points in Table A-1 could not be accurately determined in the 2008 survey since these points had not been spray painted since 2003. The points measured are deemed adequate to support the conclusions of this report. Based on the survey and observations, there has been no appreciable change in the condition of the unit sunce the 2007 inspection. The subsidence of the floor presents concerns to the building structure due to the possible indeterminate load on the pupe gallery framing. Prior to demolition actinthes that mvolve the piping or removal of the equupment, such as vent, purge and drau and foaming, enguneerng uvolvement in the planning is necessary. The piping connected to the equipment is under stress, and actions should be implemented to relieve this stress pnor to disturbing any of the equipment or associated piping. In addition, the load on the pipe gallery framing needs to be relieved pror to any acturttes taking place in the pipe gallery. Access to this area and the pupe gallery is not allowed untl the stress is releatsed. 


\section{BACKGROUND AND ISSUE/CONCERN STATEMENT}

The west end of the K-311-1 building unit contains an area of inactive equipment which formerty served as a Booster Station during facility operations. The area is located between the truck alley and the exterior watl (north-south column lines $\mathrm{l}$ and 2) and between east-west column lines $\mathrm{B}$ and $\mathrm{K}$ at the cell floor level in the K-275 Building. The floot slructure in this area consists of grade beams and concrete slab-ongrade. Due to settling of the soil beneath the floor and the dead load of the equipment contained in the area, the concrete slab has subsided significantly within the grade beams surtounding the former Booster Station area. This has resulted in structural damage to the concrete slab, piping, and equipment foundations.

To monitor the settlement, 34 points were selected in the area and settlement readings were taken in October 1970. May 1998, July 2000, October 2001, September 2002, July 2003, September 2006, November 2007 , and October 2008 to detemine the extent of settlement from its first survey in October 1970 (see Appendix A). The July 2005 inspection report concluded that the subsidence of the floor presented no immediate concerns to the building, given the status of operations and activities associated with the K-275 Building. However subsequent to that report further evaluation and inspection reveals potential loading of the pipe gallery steel framing.

\section{ASSUMPTIONS}

The foltowing assurnptions can be made:

- The building footings are stable and will not settle.

- Settlement readings in the "Difference Since $2003^{*}$ column of Table A-1. of $+/-0.01 \mathrm{ft}$ should be viewcd as negligiblc. These can bc attributed to errors associated with the accuracy of the survey equipment.

- Only a representative number of points were measured during the 2008 survey.

- The exact location of a number of survey points in Table A-l could not be accurately determined in the 2008 survey, since these points had not been spray painted since 2003 . The exact location would allow the accuracy of the survey to be within $0.01 \mathrm{ft}(1 / 8 \mathrm{in}$.). However, the survey accuracy of $0.05 \mathrm{ft}(-5 / 8 \mathrm{in}$.) that allows for comparison of previous point data to cvaluato continued settlement is deemed adequate. Further painting, given the dust, industrial bygiene issues, and as low as reasonably achievable concerns, is not necessary for further monitoring. 


\section{EVALUATION}

\section{S.1 STRUCTURAL EVALUATION}

The total settlement through July 2003 was calculated based on the readings taken from October 1970 to July 2003 and plotted on the graphs in Appendix A.

Graphs were plotted in the 2005 report for settlements at selected points to see the pattern of subsidence of the slab, based on the readings taken in the past (see Table A-1 in Appendix A). This table tracked and documented the amounts of settlemeut at 34 pre-selected points on the concrete floor from 1970 to 1998 , then in $2000,2001,2002$, and 2003 . The data shows that the rate of settlement at most of these locations, from 1998 to 2003, has decreased considerably. The maximum settlement recorded at any point (Point 30) between the years 2002 and 2003 was 0.48 in. Only a slight increase in settlement was noted at that point in the 2006 survey and, none in the 2007 and 2008 survey. Although there were signs of physical darnage to some small-bore pipes ( $<1$ in.), no breakage in large-bore pipes ( $>1$ in.) was observed. The following points of interest were noted during the 2005 inspection/survey, with updates from the 2006, 2007 , and 2008 inspections/surveys:

- The maximum settlement of 18.24 in. has occurred at Point 40 , from 1970 to 1998 . This point has potentially experienced additional settlement of $0.18 \mathrm{ft}(2.1 \mathrm{in}$.$) since 2003$. See attached photographs (Figs. B-2 and B-3 in Appendix B).

- The next significant settlements of $9.12 \mathrm{in}$. and $10.92 \mathrm{jn}$. occurred at Points 10 and 23 , also from 1970 to 1998 . Although Point 10 was not surveyed in 2007 , Point 23 has potentially cxperienced additional settlement of $0.06 \mathrm{ft}(0.72 \mathrm{in}$.) since 2003 . See attached photographs (Figs. B-5 through B-1 8 in Appendix B).

- Of particular interest in the 2007 survey is point 15 which may have experienced $0.38 \mathrm{ft}$ (4.5 in.) since 2003. Virtually no settlement was measured between 2003 and 2006 or for the 2008 survey

- Other points of significant settlement measured during the 2007 survey are $19(0.09 \mathrm{ft})$ and $4(0.06$ ft).

- The stnctural steel columns and main building framing are plumb, level, and uniform, and there are no signs of overstressing or damage to the steel framing.

- The footings for the steel columns also seem to be in good condition and show no sign of settlement, indicating that the settlement of the slab has had no significant impact on the building structure.

- The exterior elevation of the building appears to be uniform and shows no signs of deformation or damage due to the slab settlement. A minor excavation conducted in 2007 on the outside of building 3]1-1 revealed no drastic building foundation settlement or subgrade undemnining outside of the building footing.

- There is no settlement in the footings of the building. The bottoms of footings for the building are located at El. $780 \mathrm{ft} 0 \mathrm{inh}$, and the bottoms of equipment foundations are at El. $787 \mathrm{ft} 8 \mathrm{in}$. The equipment foundations are located in an area of old foundation, which was removed, and in proximity 
to the building foundations. This has caused differential settlement due to insufficient compaction of soil, combined with the softening of soil due to water leaks.

- Some of the 2007 civil survey points nay not correspond exactly to the previous locations, as these locations were last marked (spray painted) in 2003 . This could result in a \pm 0.05 -ft error in the survey. However, as noted above, Points 23 and 40 have potentially shown some additional settlement in the past three years.

\subsection{PIPING EVALUATION}

The following observations in the 2005 report remain valid for the 2008 report:

Walk-downs performed revealed deformations andor breakages in several snall-bore pipes in the vicinity of the A-Booster and B-Booster Pumps area. Because of the floor subsidence and observed darnages to small-bore pipes, it was evident that all pipes, large- and small-bore, are stressed. The visible damage, mostly on small-bore pipes, includes the following:

- Deformed or broken fitings that are disengaged from pipes

- Hanger rods that are disengaged from beam attacliments

- Expansion joints, in vertical pipes, that are elongated

- Floor-mounted components that are elevated off the floor and/or their supports resuling in the components' dead weights now being supported by the attached piping systems

See attached photographs (Figs. B-4 and B-19 through B-26 in A.ppendix B)

All of the piping systems in this area are out of service. The liquid pipelines (i.e., lube oil and coolant systems) were previously drained; therefore, only residual amounts of oil or coolant are expected to be within these systems. The nitrogen and steam systems were shut down in 2004. The process gas and dry air systems were shut down in the 1970s. The pressures in these systems are expected to be equal to the atmospheric pressure.

Further settlement of the K-311-I floor could result in the rupture of some of the piping systems. Rupture of the non-process gas systems should not cause adverse impacts to the area. However, if the process gas system piping were to rupture, radioactive contamination could migrate out of the system to the adjacent areas. The area of floor subsidence is currently barricaded and labeled as "high contamination area." 


\section{AUTHORIZATION BASIS - SAFETY BASIS COMPLIANCE}

Per Technical Safety Requirements for the East Tennessee Technology Park K-275 and K-277 Facilities, Rev. 3D, Sect. 5.6, Procedures and Programs, Sect. 5.6.2.5, Initial Testing, In-Service Surveillance, and Maintenance Program states: "The Initia] Testing, In-Service Surveillance, and Maintentance program ensures that safety Structures, Systems and Components (SSCs) (including Design Features (DFs) subject to degradation) perform their intended functions. The maintenance program is developed and implemented to ensure that maintenance activities are conducted to pteserve and restore the availability, operability and reliability of the plant SSCs important to operation of the FACLLITY and control and CALIBRATION of Measuring and Testing Equipment (M\&TE)." The first buileted item states: "The Initial Testing, In-Service Surveilance, and Maintenance Program shall establish a requirement to provide scheduled structural evaluations in the K-275/K-277 BUILDINGS." In compliance, this inspection has been performed to status the condition of the K-311-1 building floor located between the truck alley and the exterior wall (north-south column lines 1 and 2) and between east-west column lines $B$ and $K$ at the cell floot level in the K-275 Building.

\subsection{RECOMMENDATIONS}

- Do not place additional loads in the subsidence area without engineering approval.

- Maintain the posting on the exterior of the building, "Digging Requires Facility Manager Approval," $10 \mathrm{ft}$ from the building along column Jine $\mathrm{B}$ to $\mathrm{K}$.

- Any work inside the subsidence area requires engineering evaluation.

- Special engineering evaluation and planning shoujd be performed before decontamination and decommissioning activities take place that could cause disturbances or additional loading on the slab or equipment. This includes vent, purge and drain, foaming, or work in the trick alley piping that is connected to the booster station.

- Discontinue annual monitoring when the stored energy offered by suspended equipment and piping has been removed.

\subsection{CONCLUSIONS}

- The foundations for the building frame are stable, and there is no indication of any settlement.

- Additional settlement in the area since last measured in 2003 is very minor, with the exception of Points 15, 23 and 40 as noted in Table A-1. Points 4, 5, 7, 15, 19, and 24 have settlements that are noted as approximately $1 / 2$ in. or greater, but uncertainty in the survey locations could account for this difference in elevation measurements. Measurement of the points during the 2005 inspection was deemed unnecessary, since the graphs of settlement through 2003 show an extrense decline in the amount of settlenent. The swrvey measurements were taken in 2008 to evaluate any additional potential of settlement. Since the locations of the past surveys have not been marked since 2003 , the 2006 survey location may bave been taken in an atea up-siope or down-siope of the exact point, resulting in a survey delta of $\pm 0.05 \mathrm{ft}$. 


\section{REFERENCES}

Engineering Evaluation Report on K-3L1-l Floor Subsidence (2007 Anmual Report) at the East Tennessee Technology Park, Oak Ridge, Tennessee, BJC/OR-2345/R2, November 2007

Engineering Evaluation Report on K-311-1 Floor Subsidence (2006 Anmual Report) at the East Tennessee Technology Park, Oak Ridge, Tennessec, BJCJOR-2345/R1, November 2006

Engineering Evaluation Report on K-311-1 Floor Subsidence at the East Tennessee Technology Park, Oak Ridge, Tennessee, BJC/OR-2345, October 2005.

Facility Management, Surveillance, Inspection and Testing, Annual Inspection Report for the K-31 1-1 Floor Subsidence Survey and Evaluation, prepared by American Technologies, Inc., August 2003 .

Techrical Safety Requirements for the East Tennessee Technology Park K-275 and K-277 Facilities, TSR-ET-K25/K27-0002, Rev. 3D, Bechtel Jacobs Company LLC, June 2005.

K-275 Structural Drawings:

1. AWS-8169-0

2. AWS-8170-0

3. 311-1-A-20-AA

4. 311-1-A-20-BA

5. 3]1-1-A-20-CA

6. 311-1-A-40-BA

7. 311-A-1-A-40-ZA-2

K-275 Mechanical Drawings:

1. AWP-7831

2. AWP-7850-1

3. AWP-8073

4. AWP-8074-1

5. AWP-8119

6. AWS-8170-0

7. 300-M-19-GA311-M-05-DA 
APPENDIX A.

TABLE OF SETTLEMENT ELEVATIONS (FROM ATI REPORT) AND 2006 REPORT

K-311-1 FLOOR SUBSIDENCE SURVEY AREA SKETCH (FROM ATI REPORT), AND SETTLEMENT GRAPHS 
Table A-1. Elevations in K-311-1 (former Bonster Station)*

\begin{tabular}{|c|c|c|c|c|c|c|c|c|c|c|}
\hline $\begin{array}{l}\text { Shot } \\
\text { No: }\end{array}$ & $\begin{array}{l}\text { 10/1/70 } \\
\text { Elev. } \\
\text { (ft) }\end{array}$ & $\begin{array}{c}7 / 18 / 00 \\
\text { Elev. } \\
(\mathrm{ft})^{2}\end{array}$ & $\begin{array}{c}\text { 10/9/01 } \\
\text { Elev. } \\
\text { (ft) }\end{array}$ & $\begin{array}{c}9 / 13 / 02 \\
\text { Elev. } \\
\text { (ft) }\end{array}$ & $\begin{array}{l}\text { J/31/133 } \\
\text { Ekev. } \\
\text { (fic) }\end{array}$ & $\begin{array}{l}\text { 9/27/66 } \\
\text { Elev. } \\
\text { (fi) }\end{array}$ & $\begin{array}{c}1 / 12 / 07 \\
\text { Eley. } \\
\text { (ft) }\end{array}$ & $\begin{array}{l}\text { 10006/019 } \\
\text { Elev. } \\
\text { (fit) }\end{array}$ & $\begin{array}{c}\text { Difference } \\
\text { Since Latest } \\
\text { Data (ft) }\end{array}$ & Description \\
\hline $\mathbf{I}$ & 79578 & 79573 & 79574 & 79573 & 79573 & $\mathrm{NA}$ & NA & & NA & Top of grade beam \\
\hline 2 & 79567 & 79565 & 79565 & 79564 & 79566 & NA & NA & & NA & Top of grade beam \\
\hline 3 & 79571 & 79563 & 79565 & 79564 & 79565 & NA & NA & & NA & Top of grade beam \\
\hline 4 & 79528 & 79458 & 79455 & 79450 & 79447 & $\dot{\mathrm{N} A}$ & 79441 & 79437 & -004 & Slab at gas cooler \\
\hline 5 & 79545 & 7952 & $7952 \mathrm{I}$ & 79521 & 79521 & 79317 & NA & 79522 & 005 & Slab at exteror wall \\
\hline 5 & $795 \overline{75}$ & 79567 & 79569 & 79568 & 79568 & 79568 & 79569 & & $\overline{\mathbf{N} A}$ & Top of grade beam \\
\hline 7 & $7 \overline{9541}$ & 79511 & 79515 & 79514 & 79513 & 79509 & NA & & $\overline{\mathrm{N}}$ & Slab at gas cooletr \\
\hline 8 & 79525 & 79458 & 79459 & 79457 & 79456 & NA & 79456 & 79454 & -002 & Slab al purntp motor \\
\hline 9 & 79522 & 79474 & 79472 & 79470 & 79468 & NA & 79473 & & NA & Slab at putop \\
\hline 10 & 79526 & 79452 & 79452 & $794 \mathbf{5 0}$ & 79450 & 79449 & NA & 79450 & 000 & Slab at pump notor \\
\hline 11 & 79514 & 79482 & 79482 & 79481 & $794 \mathrm{BO}$ & NA & NA & $7949]$ & 009 & Slab at pump \\
\hline 12 & 79508 & 79474 & 79475 & 79474 & 79474 & 79473 & 79472 & 79477 & 005 & Slab at pump \\
\hline 13 & 79531 & 79485 & 79479 & 79477 & 79477 & 79475 & 79476 & 79482 & 006 & Slab at pump motor \\
\hline 14 & 79561 & 7955 & 79549 & 795.48 & 79548 & 79549 & NA & & NA & Slab at doonvay \\
\hline 15 & 79548 & 79524 & 79525 & 79525 & 79526 & 79525 & 79488 & 79484 & .004 & Slab at pump motor \\
\hline 16 & 79506 & 79472 & 79474 & 79475 & 79473 & 79472 & 79475 & & $\mathrm{NA}$ & Slab at pump \\
\hline 17 & 79571 & 79566 & 79569 & 79568 & 79568 & 79569 & $\mathrm{NA}$ & 79570 & 001 & Top of grade beam \\
\hline 18 & 79538 & 79487 & 79490 & 79489 & 79489 & 79487 & 79489 & 79488 & -001 & Slab at pump motor \\
\hline 19 & 7953 & 795 & 79502 & 79501 & 79502 & NA & 79493 & & $\mathrm{NA}$ & Slab at pipe housing \\
\hline 20 & 79566 & 79562 & 79563 & 79563 & 79563 & 79564 & 79564 & & $\mathrm{NA}$ & Slab at pipe housing \\
\hline 21 & 79569 & 79565 & 79567 & 79567 & 79567 & 79567 & 795.68 & 79569 & 001 & Top of grade beatn \\
\hline 22 & 79568 & 79561 & 79563 & 79563 & 79562 & 79563 & 79564 & 79564 & 000 & Slab at extenor wall \\
\hline 23 & 79545 & 79454 & 79454 & 79454 & 79454 & 79448 & 79448 & 79449 & 001 & Slab at punnp motor \\
\hline 24 & 79538 & 79496 & 79595 & 79494 & 79498 & 79494 & 79494 & & NA & Slab at pump housing \\
\hline 25 & 79571 & 79568 & 79569 & 79569 & 79570 & 79570 & 79569 & 79571 & 002 & Slab at exkerıor wall \\
\hline 26 & 79562 & 79532 & 79535 & 79534 & 79534 & 79534 & 79534 & 79527 & 4007 & Shab at putnp motor \\
\hline 27 & 79552 & 79519 & 79521 & 79520 & 79519 & NA & 79521 & 79528 & 007 & Slab at prop housing \\
\hline 28 & 79567 & 79565 & 79566 & 79566 & 79567 & $\mathrm{NA}$ & $\mathrm{NA}$ & & NA & Top of grade beam \\
\hline 29 & 79556 & 79538 & 79540 & 79540 & 79539 & 79538 & 79539 & 79540 & 001 & Slab at purtip motor \\
\hline 30 & 79559 & 79526 & $79527^{(0)}$ & 79528 & 79524 & 79522 & 79523 & 79525 & 002 & Slab at pump \\
\hline 31 & 79556 & 79519 & 79521 & 79520 & 79519 & 79520 & 79521 & 79520 & 001 & Slab at pupe housmg \\
\hline 32 & 79566 & 79563 & $79564^{(0)}$ & 79564 & 79564 & 79564 & $\mathrm{NA}$ & 79563 & -001 & Top of grade beam \\
\hline 33 & 79569 & 79566 & 79568 & 79568 & 79568 & 79571 & NA & & NA & Top of grade beam \\
\hline 40 & 79566 & 79398 & $79419^{\alpha 9}$ & 79419 & 79419 & 79414 & 79401 & 79399 & -002 & Broken slab on grade \\
\hline
\end{tabular}

-This sable has ben unperted from ATI's 2003 report and is reformathod

- See Fig A I for gipheal depercon of survey pounts

- 1998 diela has been roundod to nearesl 001 in

-Achual shot Iocalons for 1970 and 1998 surveys węre nol marked in the ficld Locabons for 2000 survey werte approximated from photocopy of

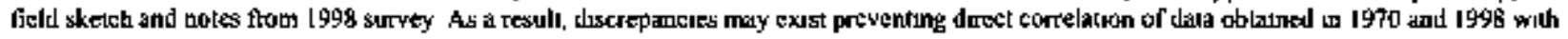
that obtained dunng the 2000 survey

${ }^{4}$ Iraccessible in 1958

'Points 30, 32, and 40 have becn remarked Surveyors conld thot locate 2001 survey pant mark for Points 30, 32, and 40 Therefore, the difference in elevelon is aol relevant

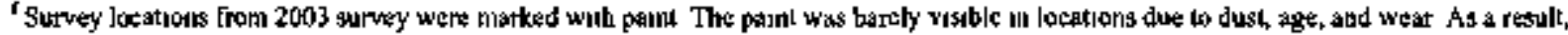
descrepancies in achual bocations may result in elesation dufferences of to to $\mathrm{ft}$

NA - Not Accessible or location could not be found 


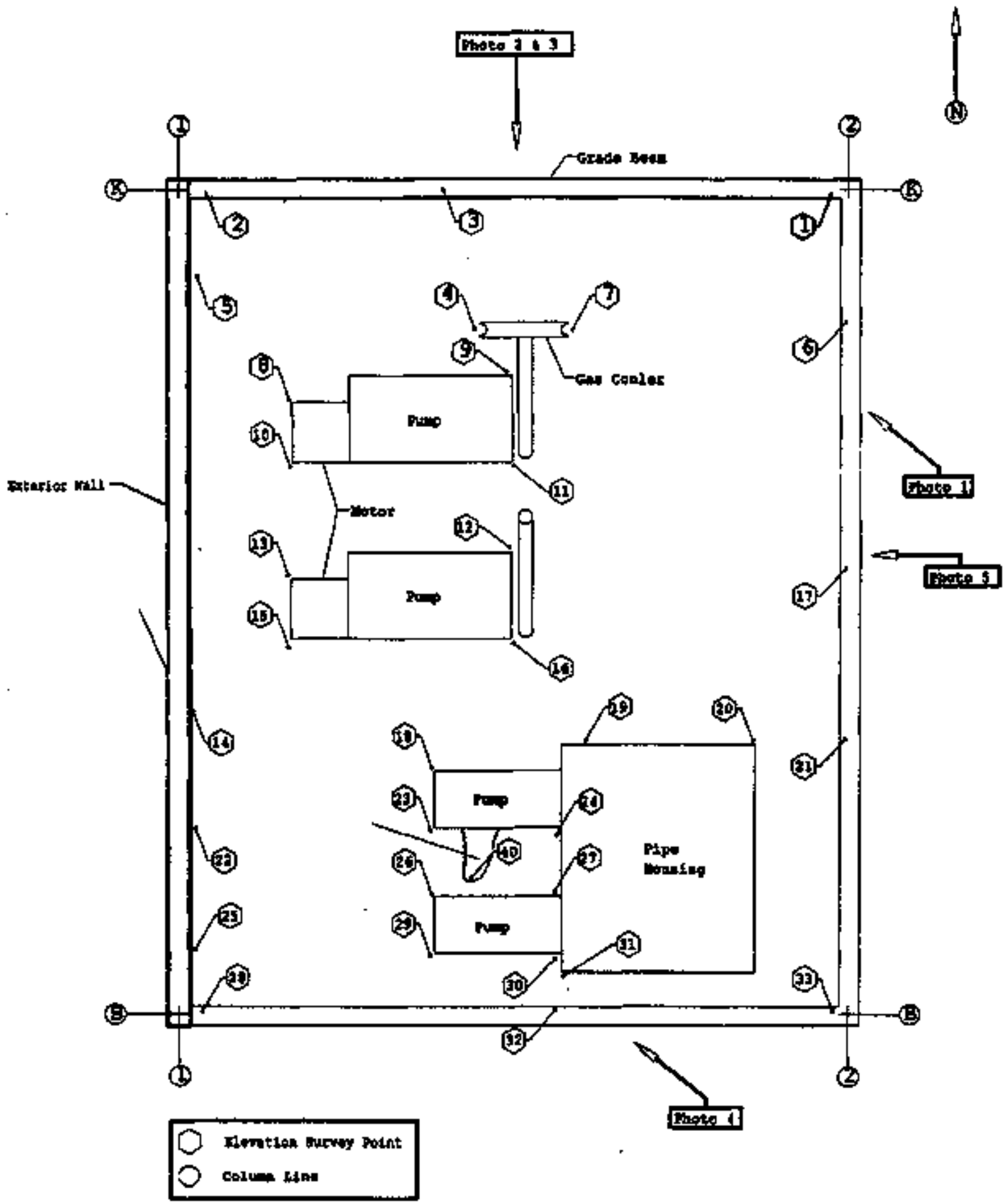

Fig. A-1. K-311-1 floor subsidence sorvey area reference sketch.

Note: This sketch and the refertaced photos (th Appendix $\mathrm{C}$ ) are imported from the 2003 report and arc included here for information only. Noxe that Pheto 5 is not wrailable. 


\section{POINT 23}

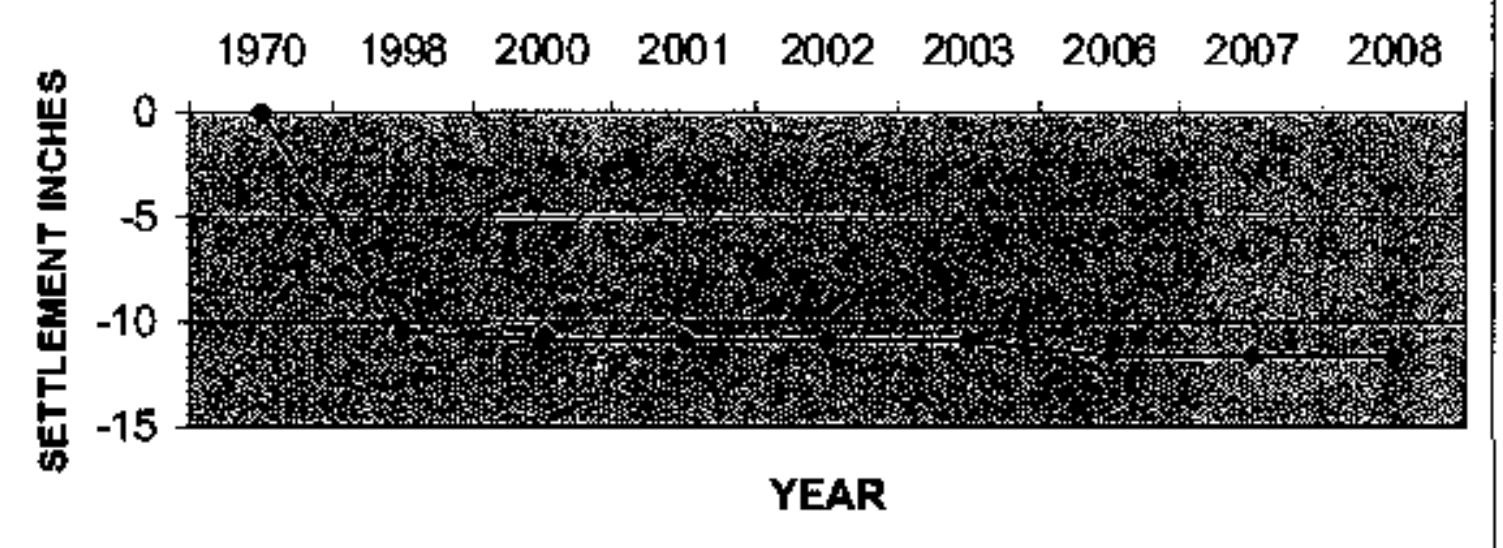

Fig. A-2. Polnt 23-Settlement In pump area.

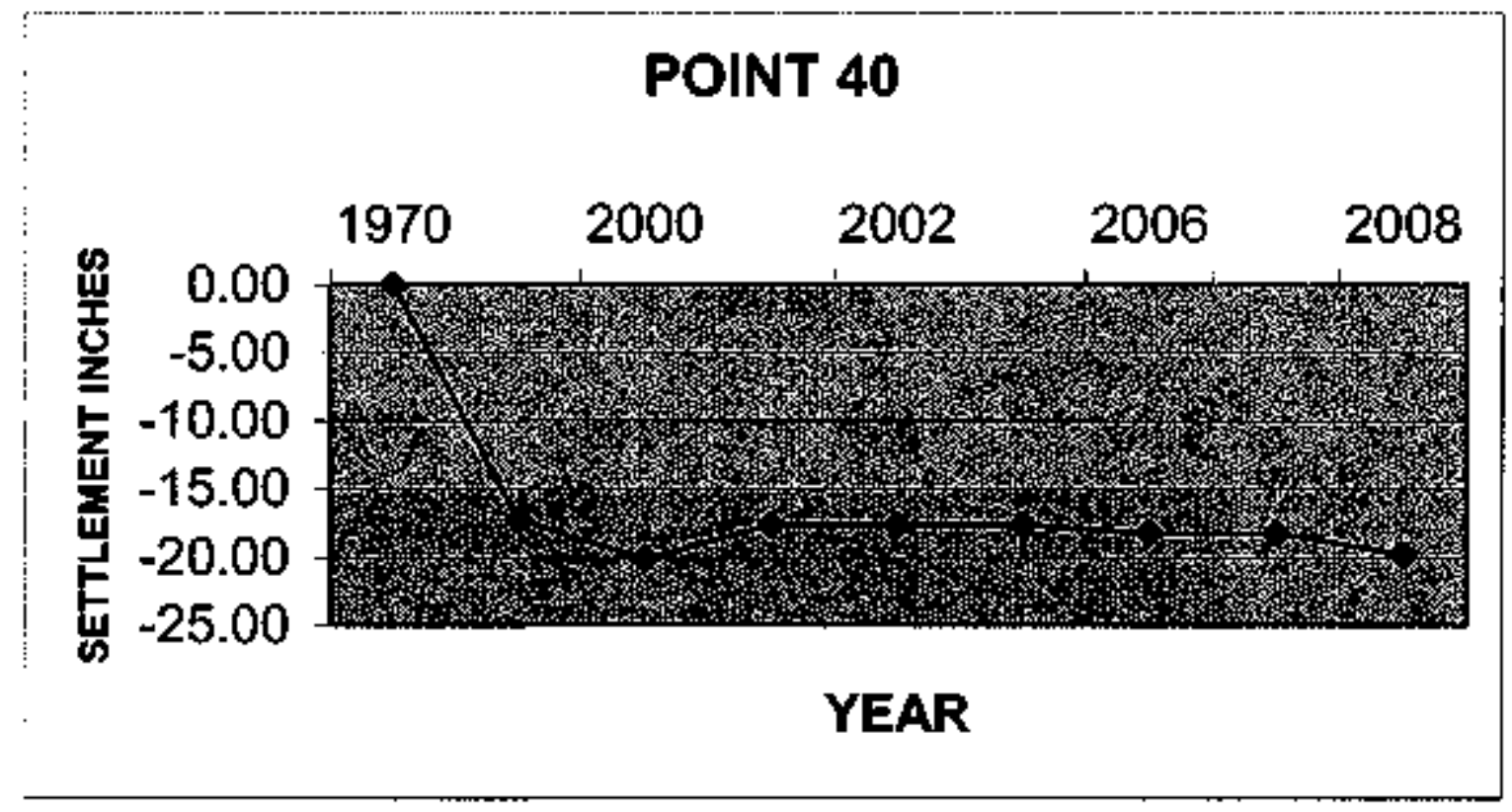

Fig. A-3. Point 40-Settlement in pump area. 


\section{POINT 7}

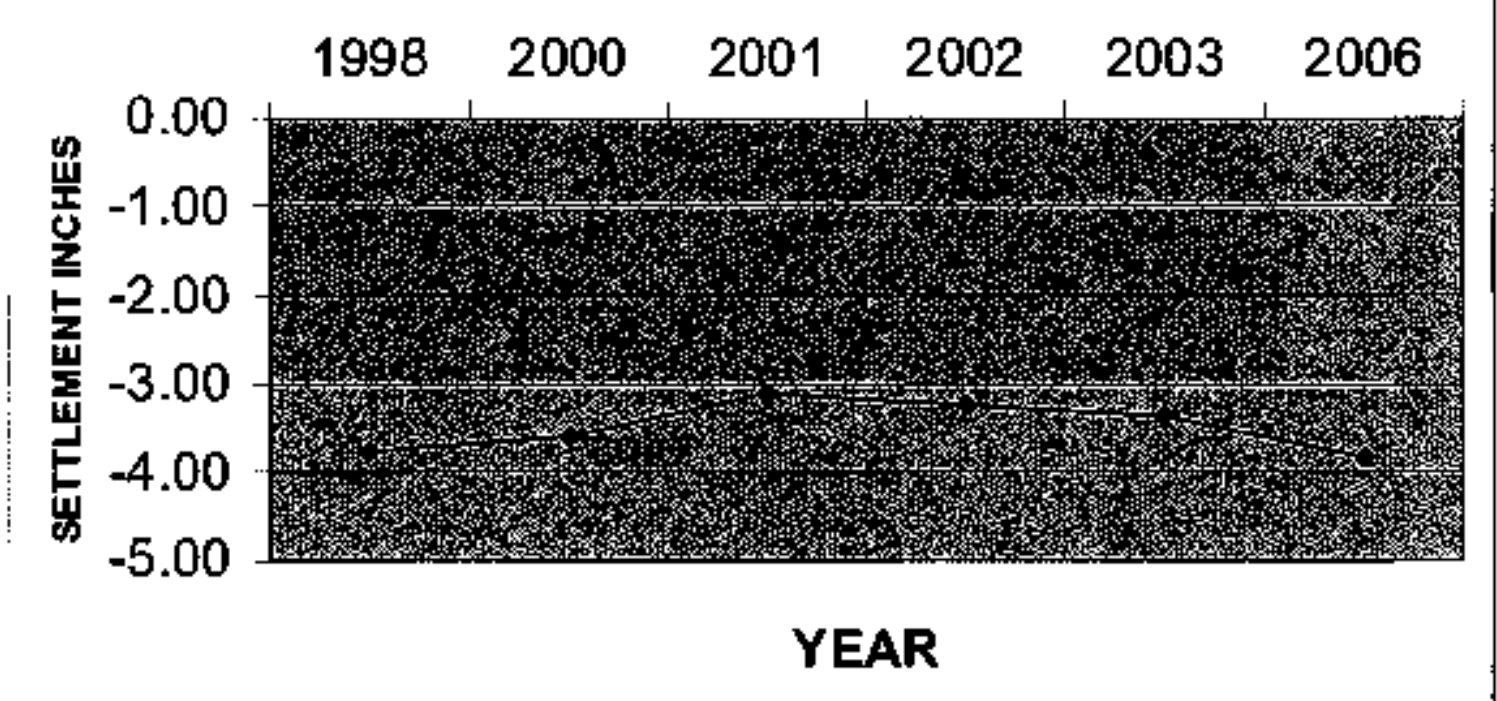

Fig. A-4. Point 7-Settlement in pump area*.

"No shot taken in 2007.

\section{POINT 8}

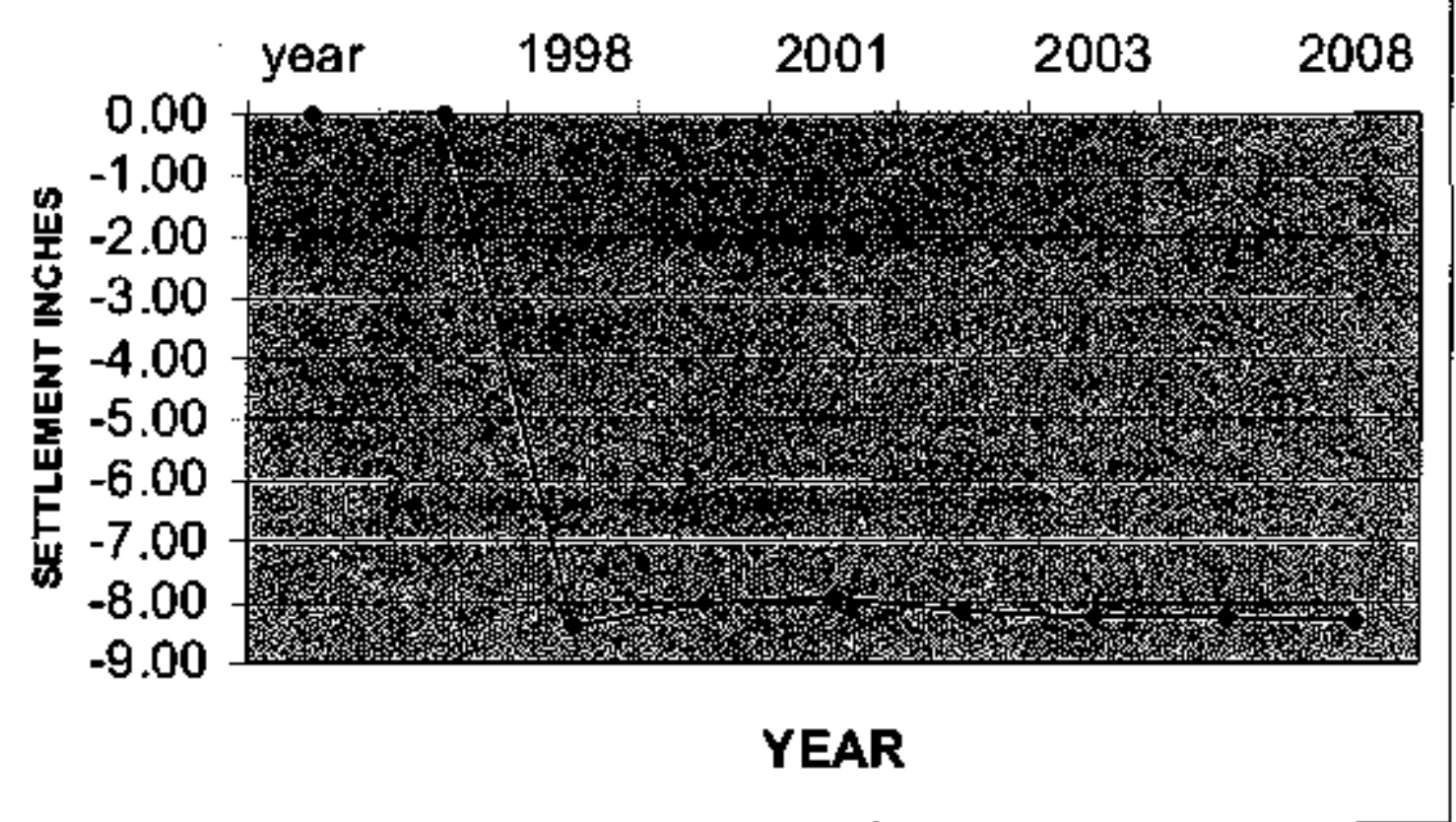

Fig, A-5. Point \&-Settlentent in pump area. 


\section{POINT 9}

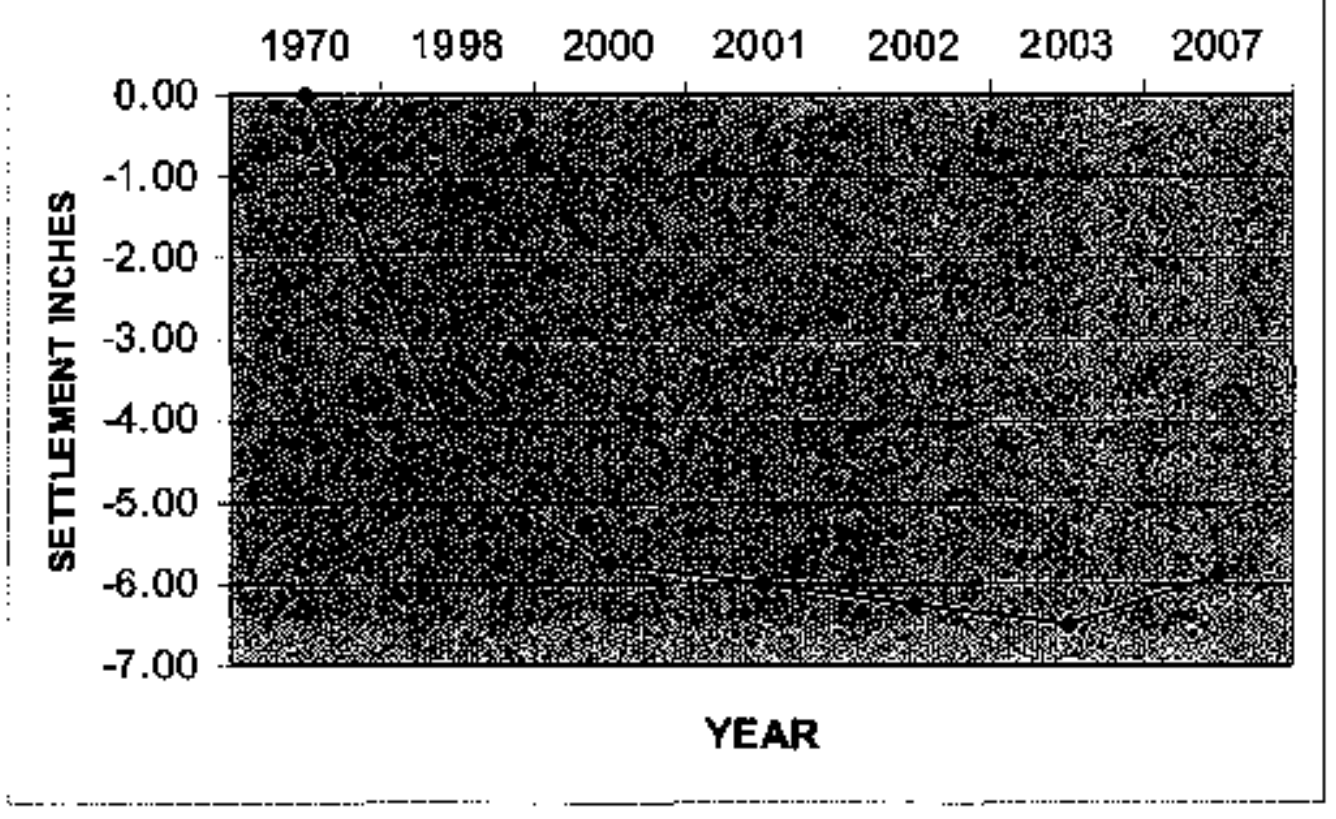

Flg. A-6. Paint 9-Settlement ín pomp area.

\section{POINT 10}

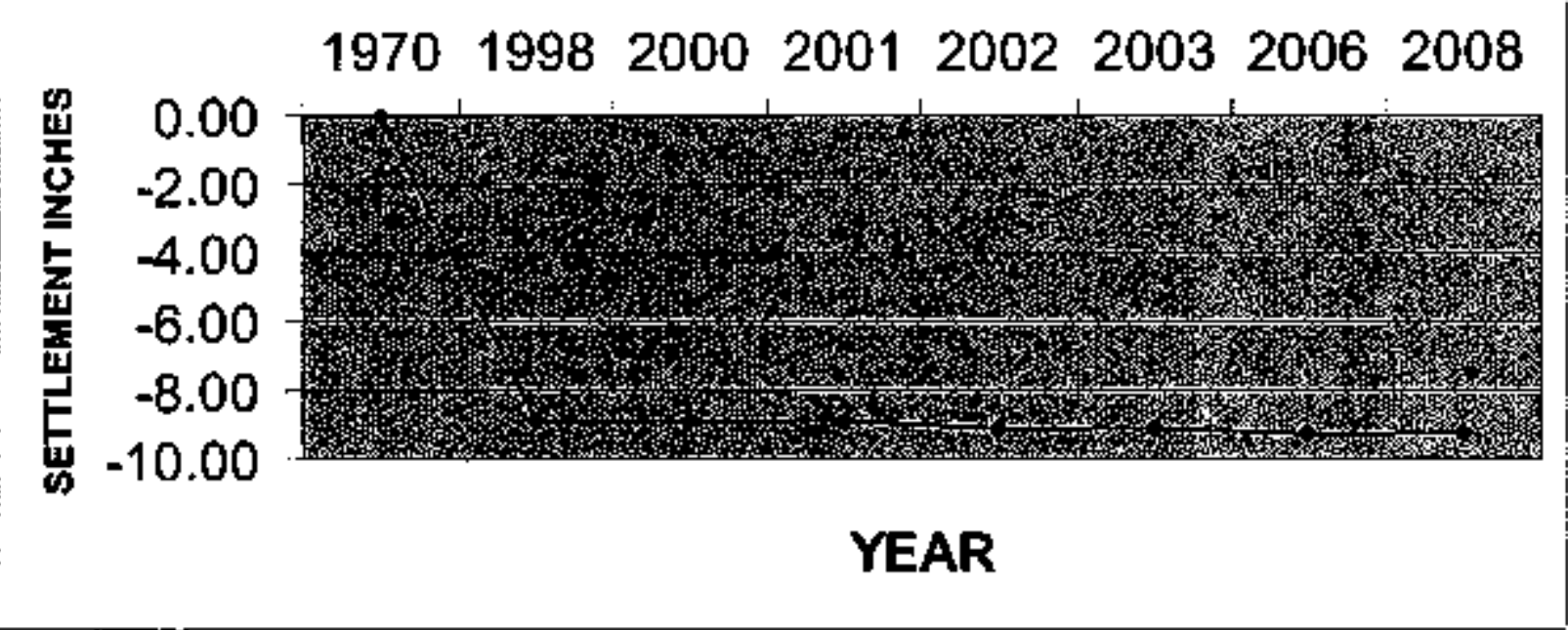

Fig. A-7. Point 10-Setdement in pump area*.

"No shot iaken in 2007. 


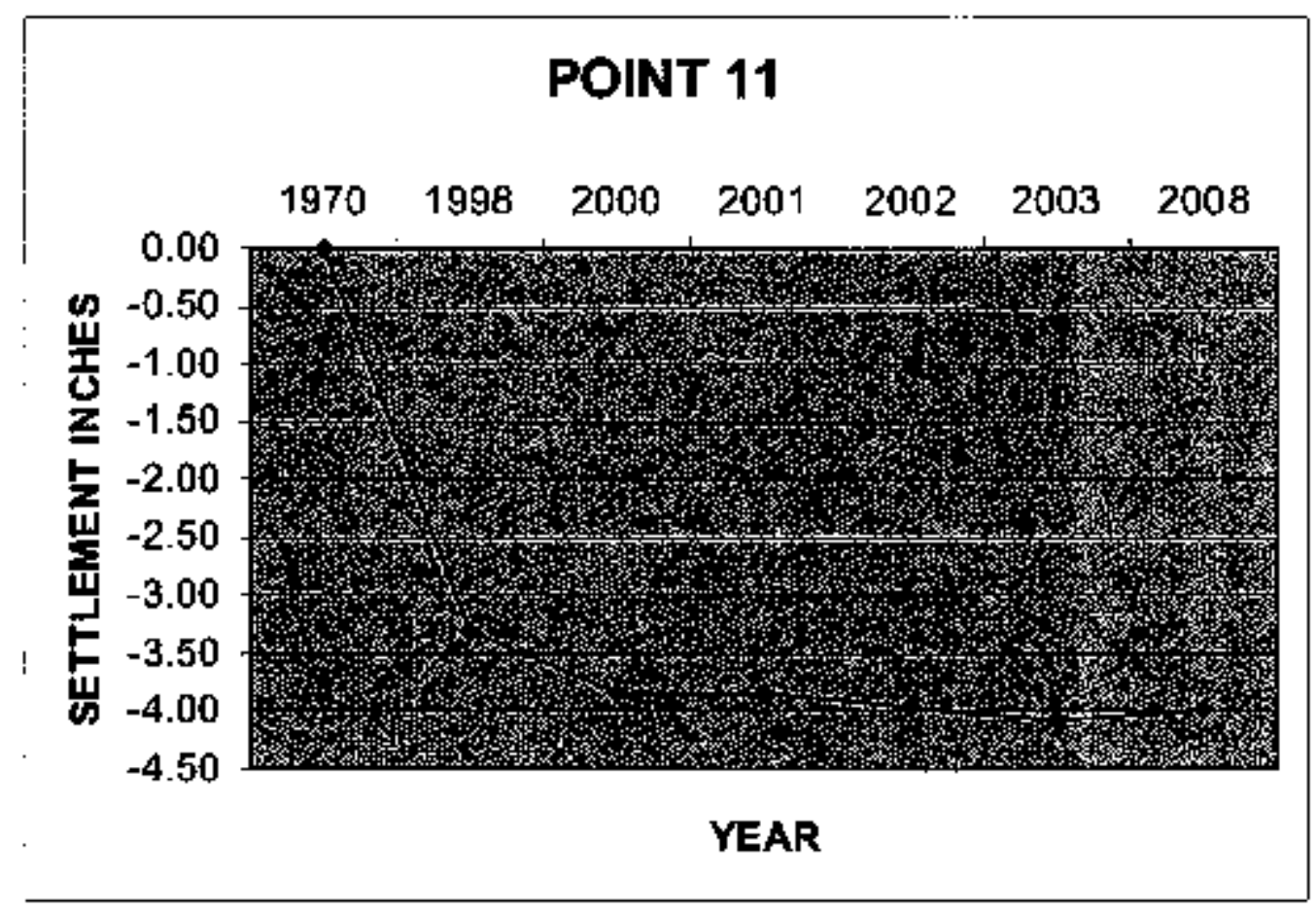

Fig. A-8. Point 11-Settlement in pump area*,

"No shot takeu since 2003.

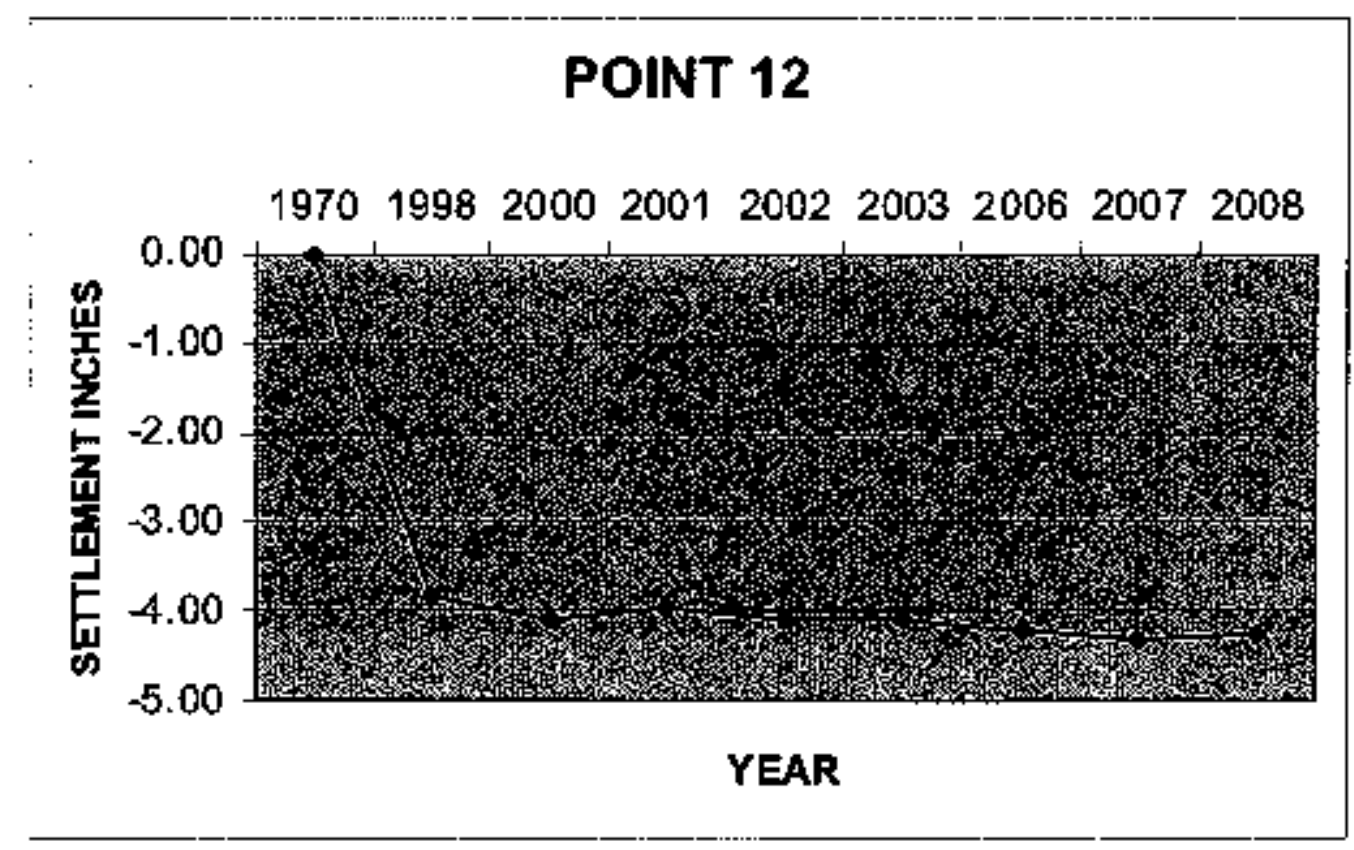

Fig. A-9. Point 12-Settlement lo pump area. 


\section{POINT 15}

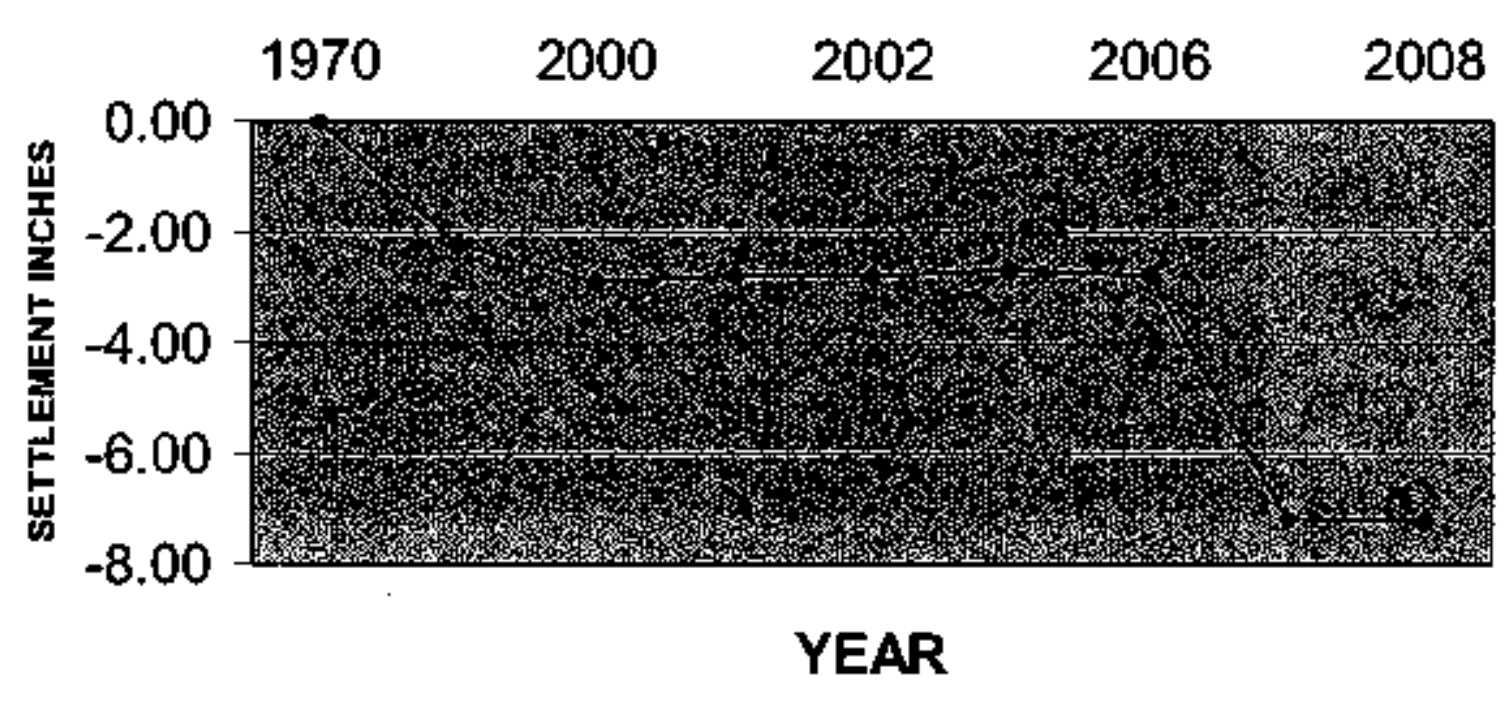

Fig. A-10. Point 15-Settlement in pump area.

\section{POINT 16}

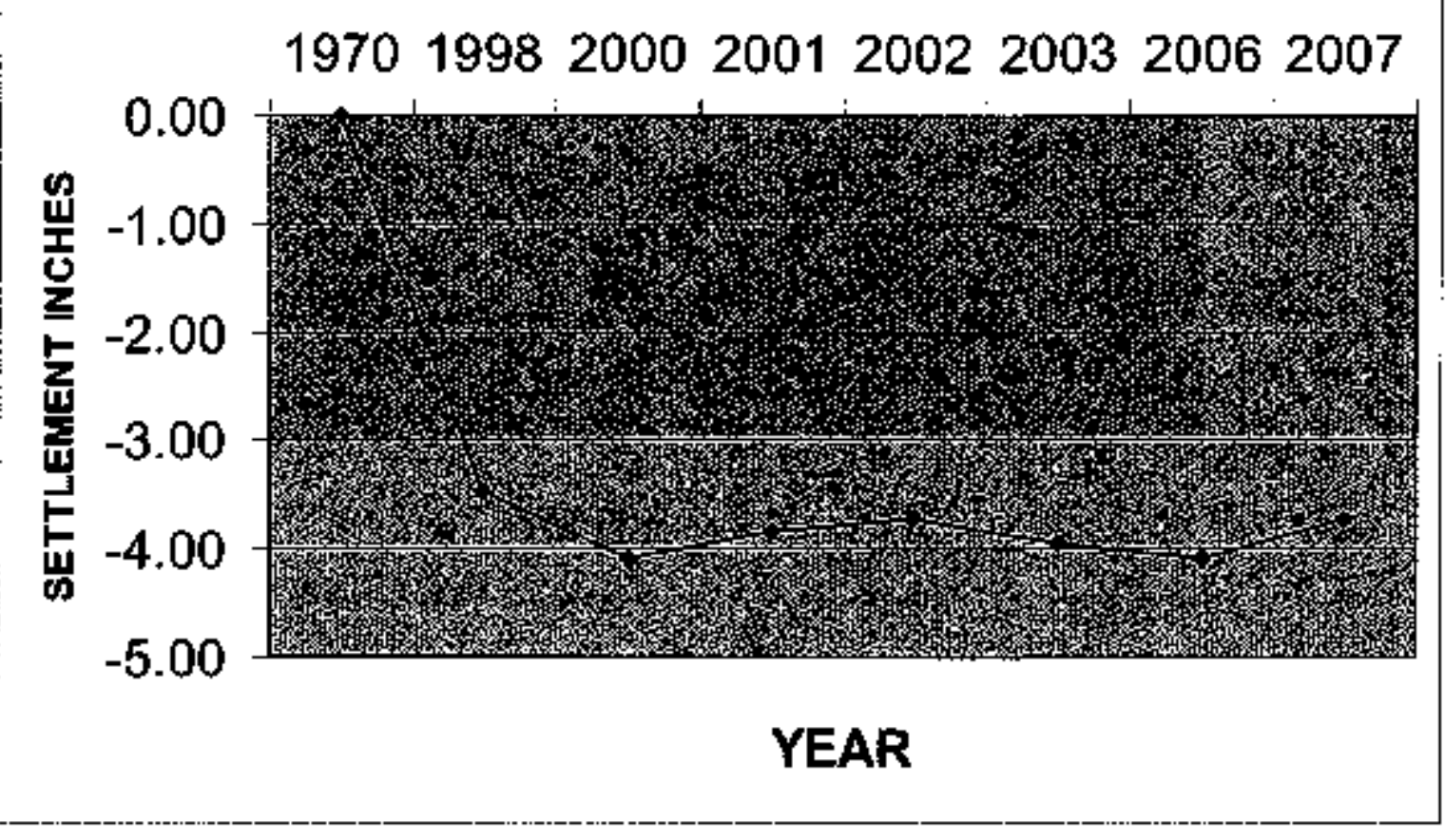

Fig. A-11. Point 16-Settlement in pump area. 


\section{POINT 18}

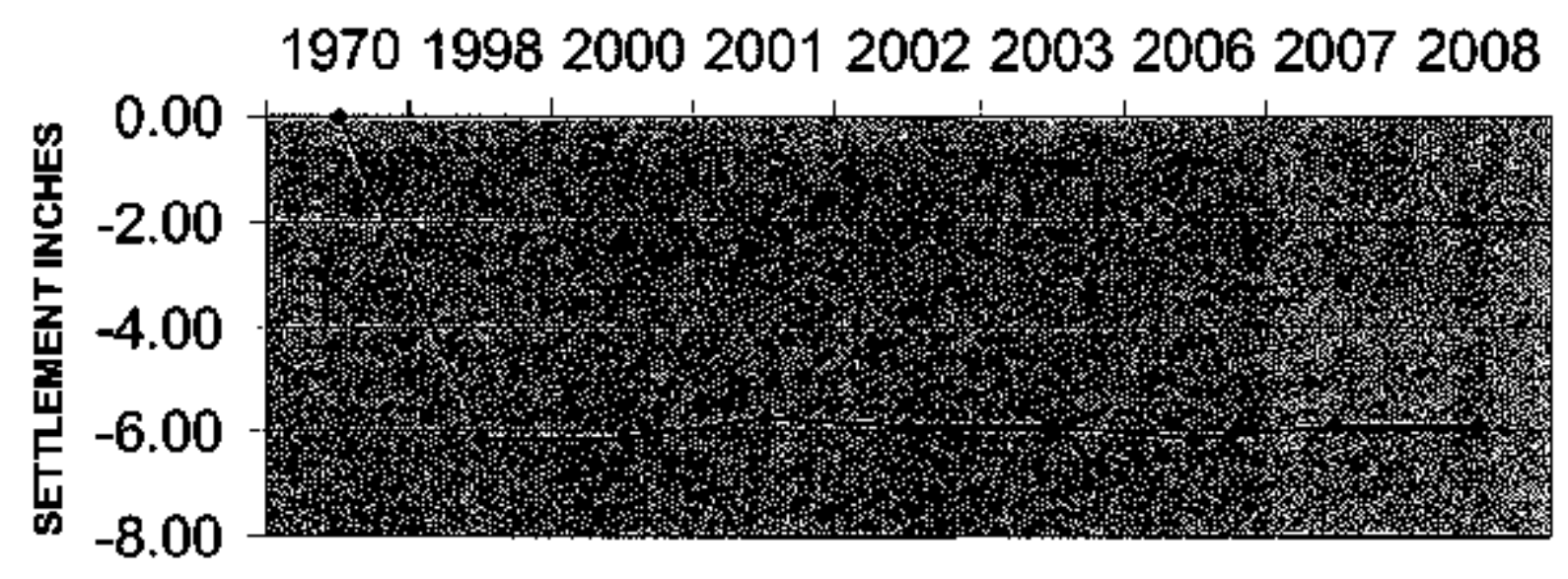

YEAR

Fig A-12. Poist I8-Settlement in pamp area.

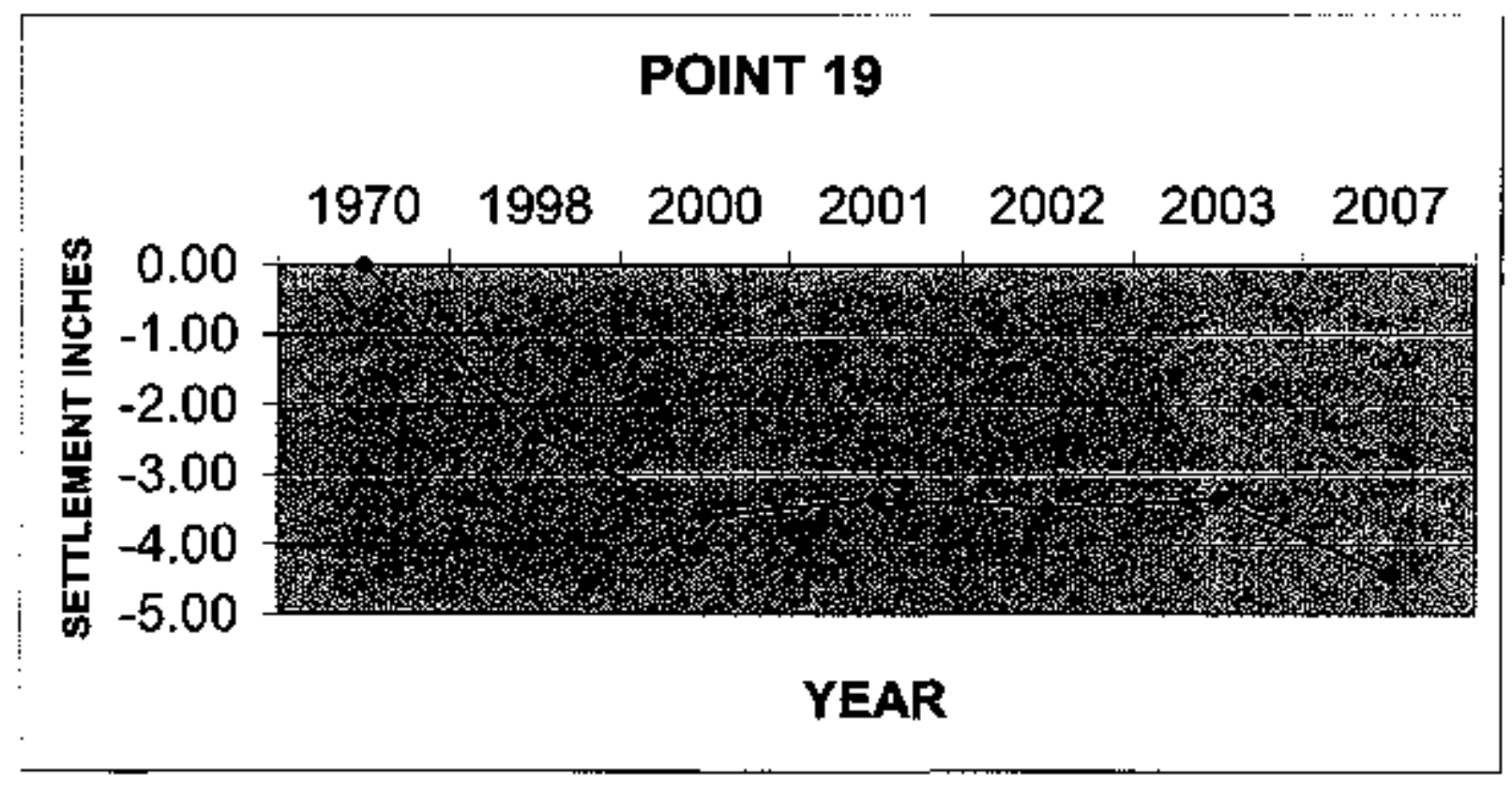

Flg. A-13. Polnt 19-Settement in pump area. 


\section{POINT 24}

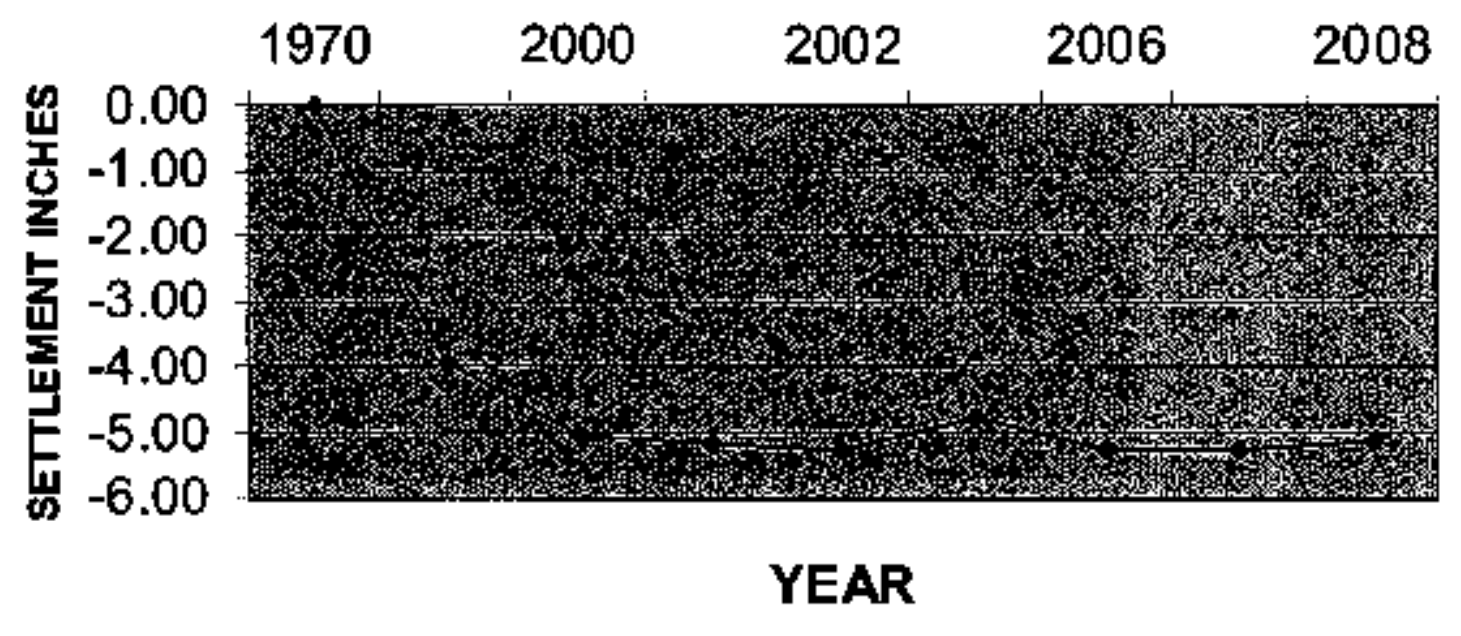

Fig. A-14. Point 24-Settlement in pump area.

\section{POINT 26}

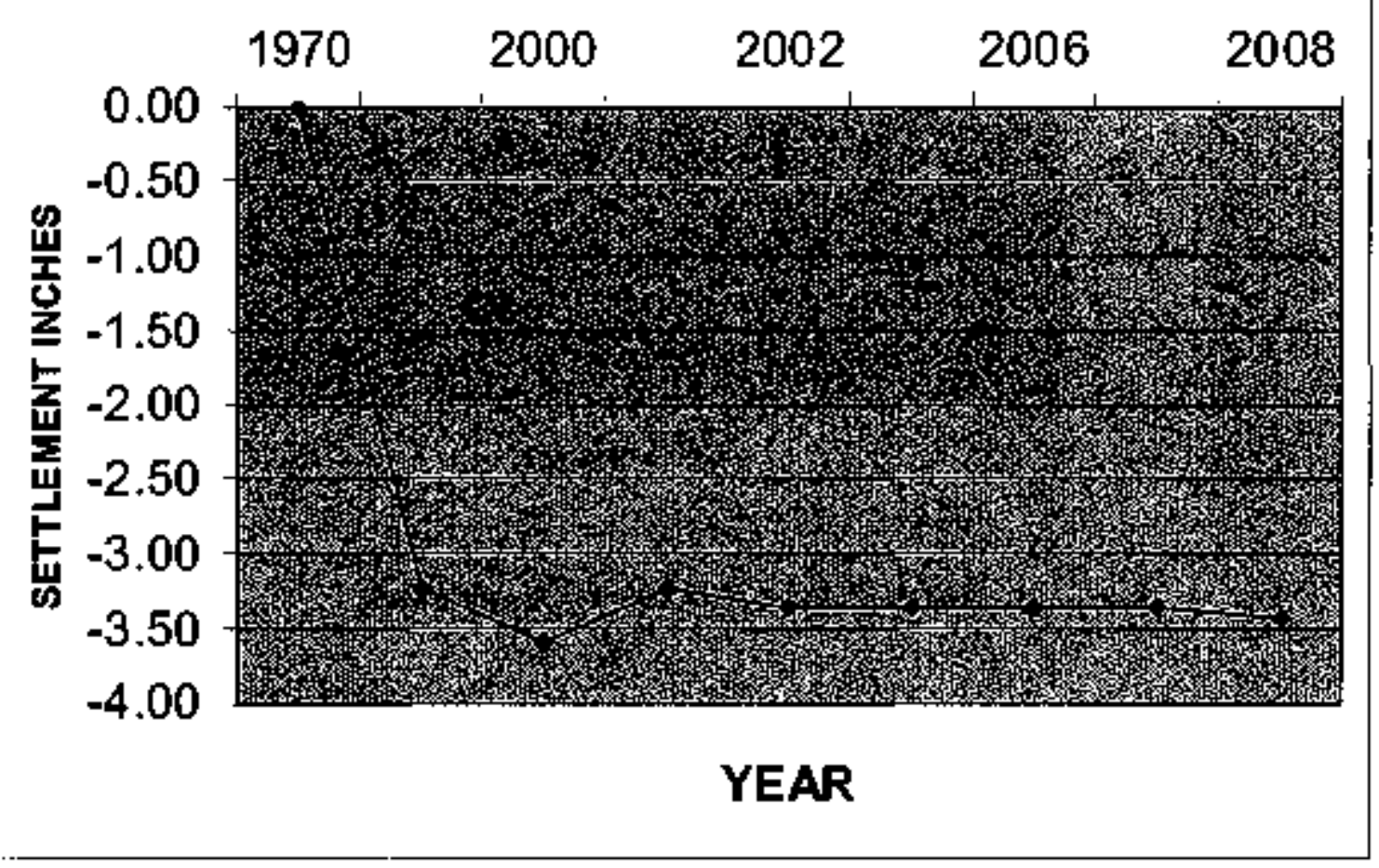

Fig. A-15. Point 26-Settienent in pump area, 


\section{POINT 27}

$\begin{array}{llllllll}1970 & 1998 & 2000 & 2001 & 2002 & 2003 & 2007 & 2008\end{array}$
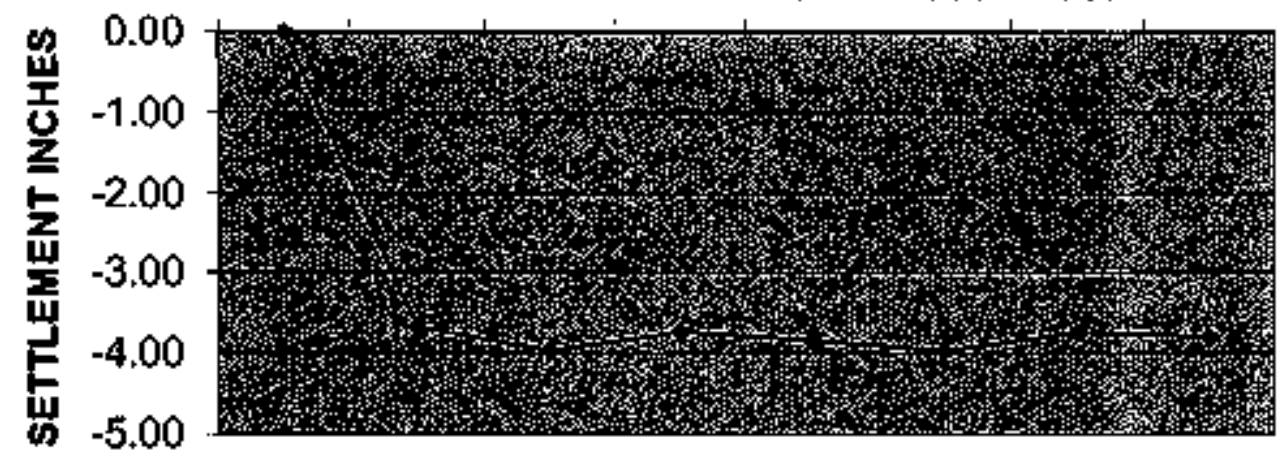

YEAR

Fig. A-16. Point 27-Settlempent in pump area.

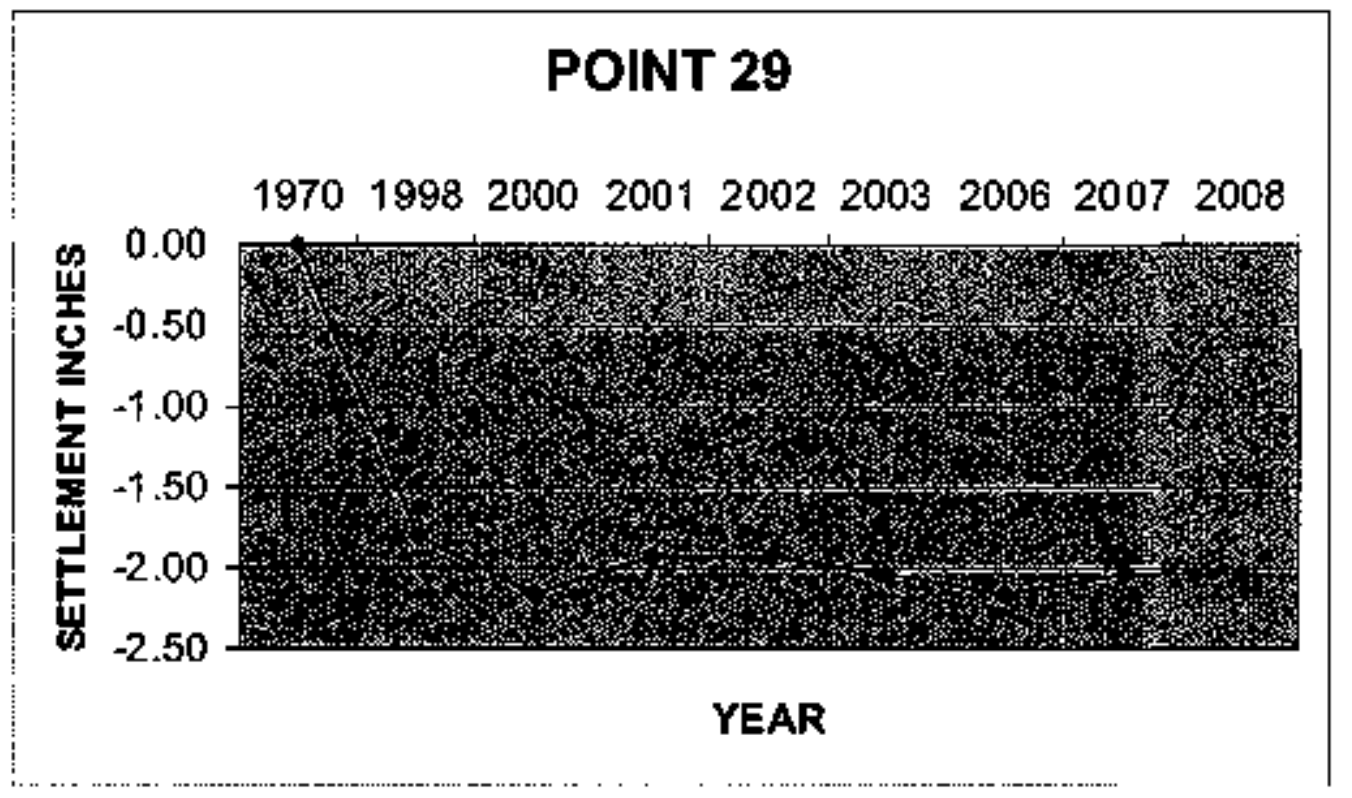

Fig. A-17. Point 29-Settlemeat in pump area. 


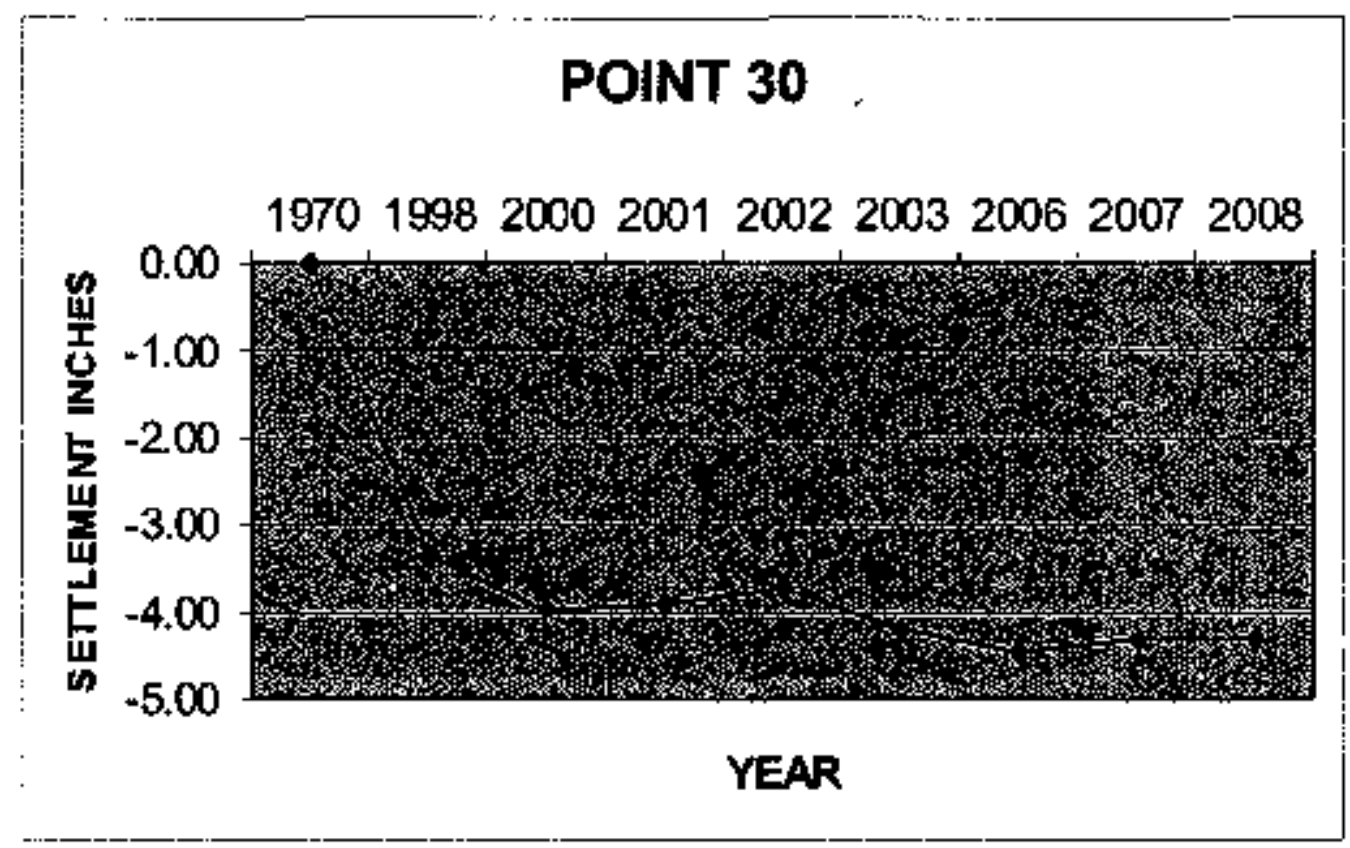

Fig. A-18. Poist 30-Settlemeat in paup area.

\section{POINT 31}

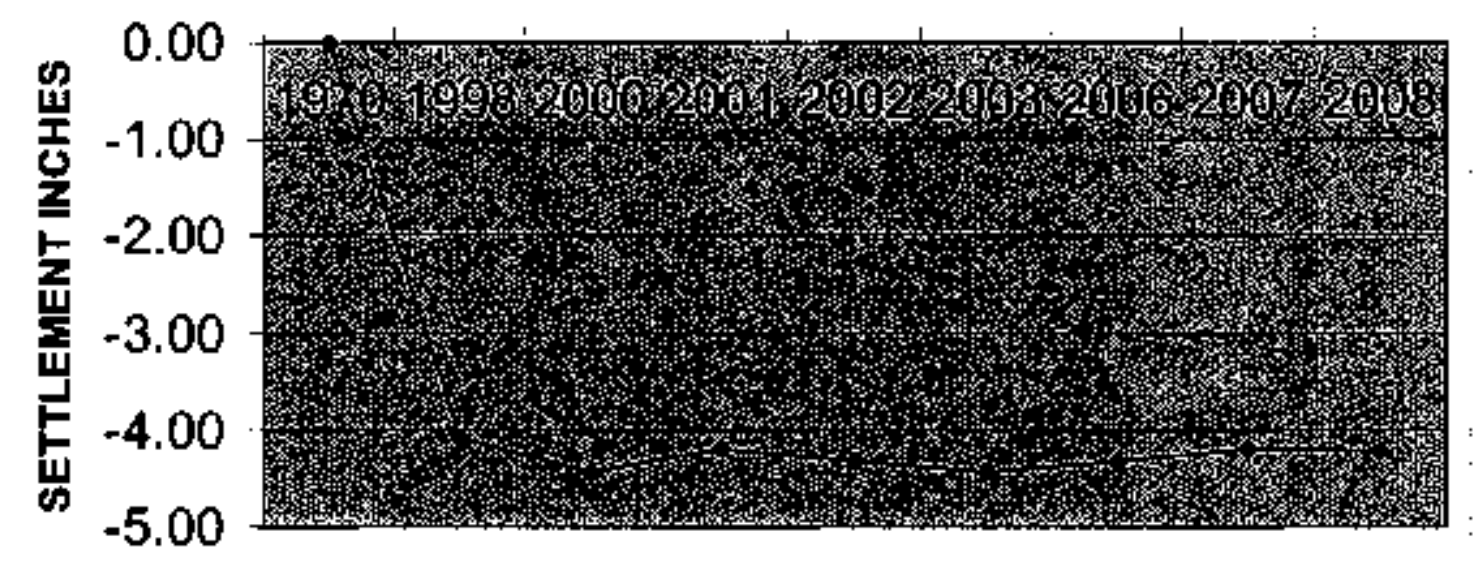

YEAR

Fig, A-19. Point 31-Settlement in pump area. 


\section{PONT 32}

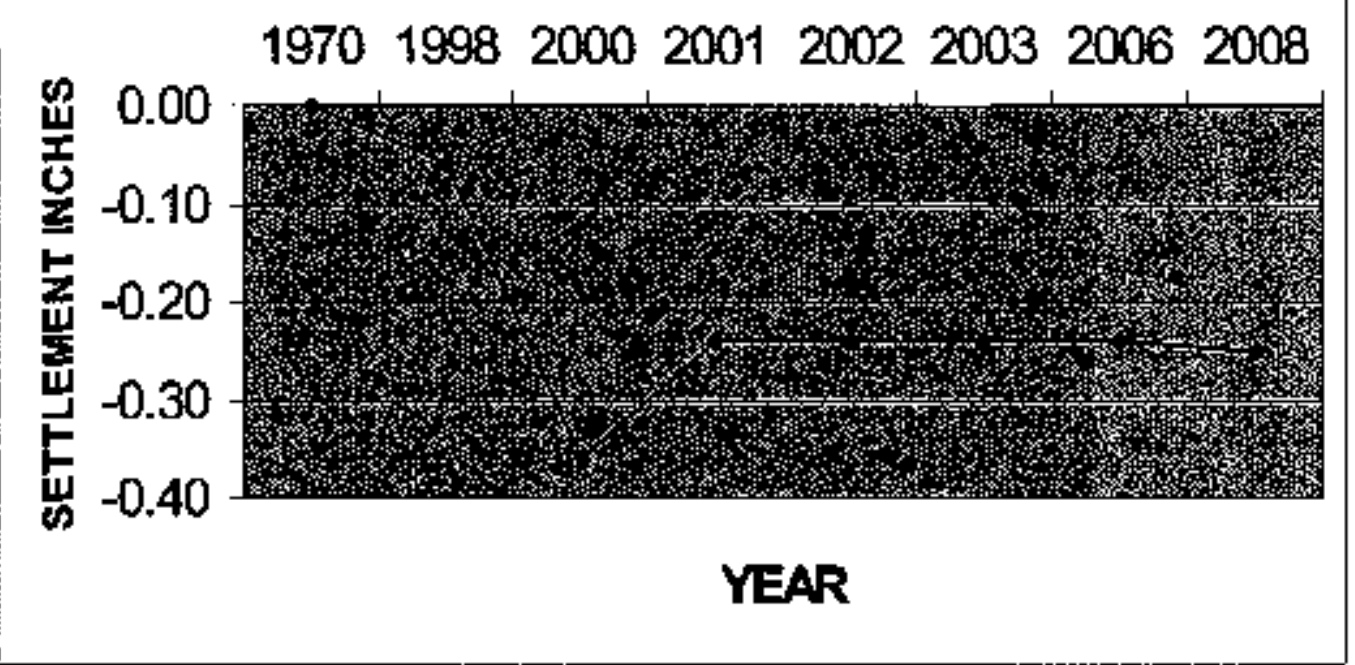

Fig. A-20. Point 32-Settlement gt grade beam*.

-No shol token in 2007.

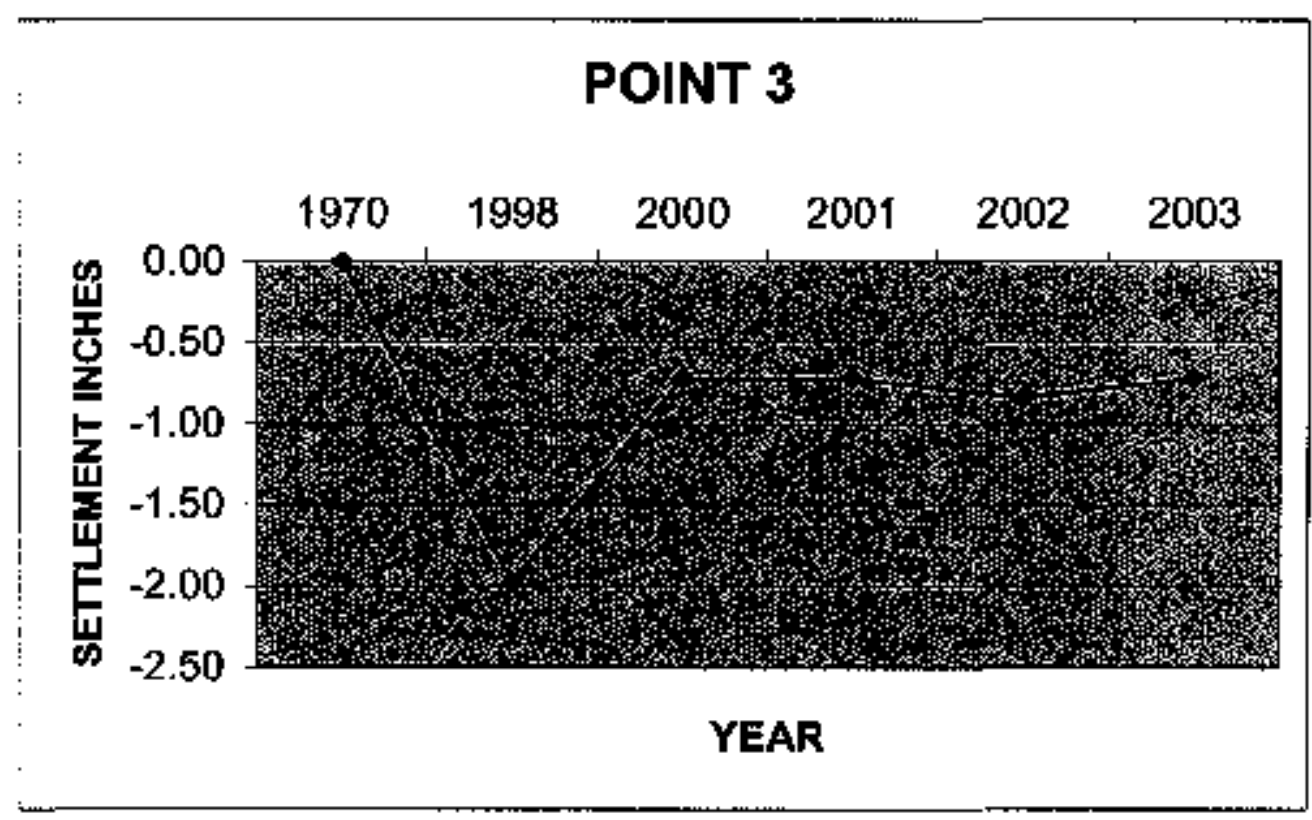

Fig. A-21. Point 3-Settlement at grade bean**

*No shat taken aince 2001. 


\section{POINT 17}

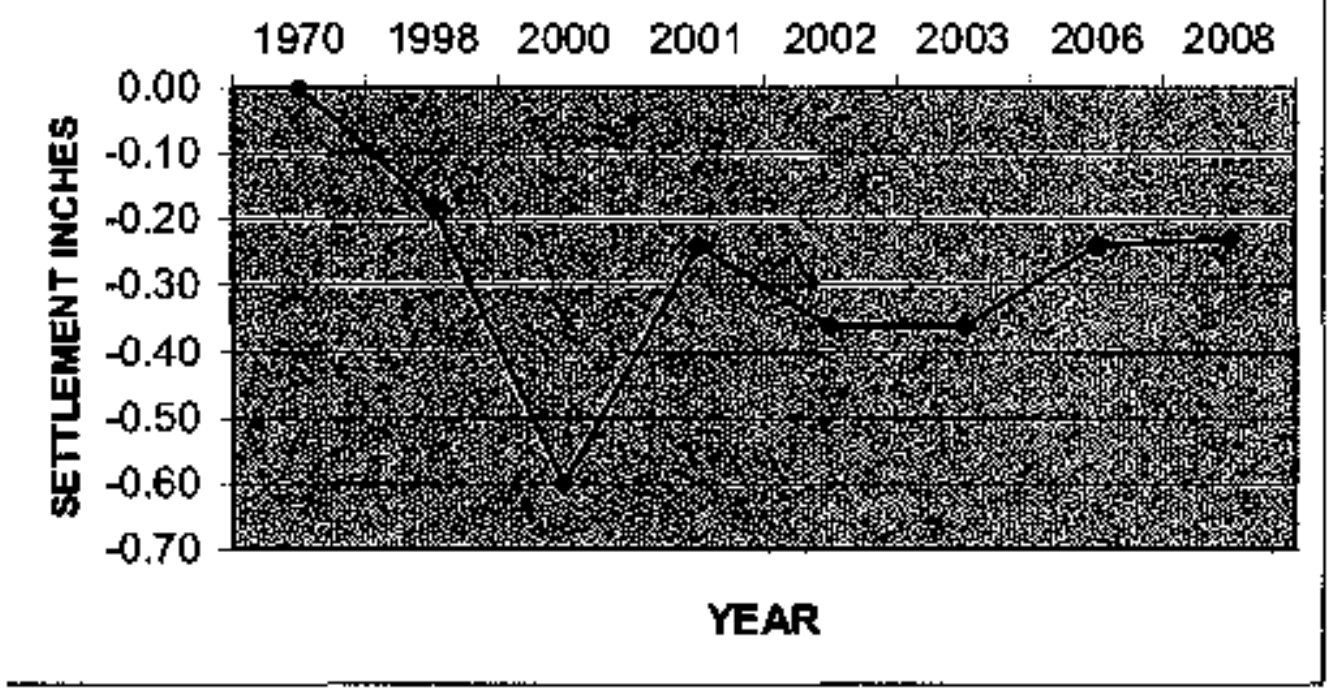

Fig. A-22. Polnt 17-Settlement at grade beam*.

"No shot laken in 2007. 
APPENDIX B.

2005 FIELD PHOTOS 


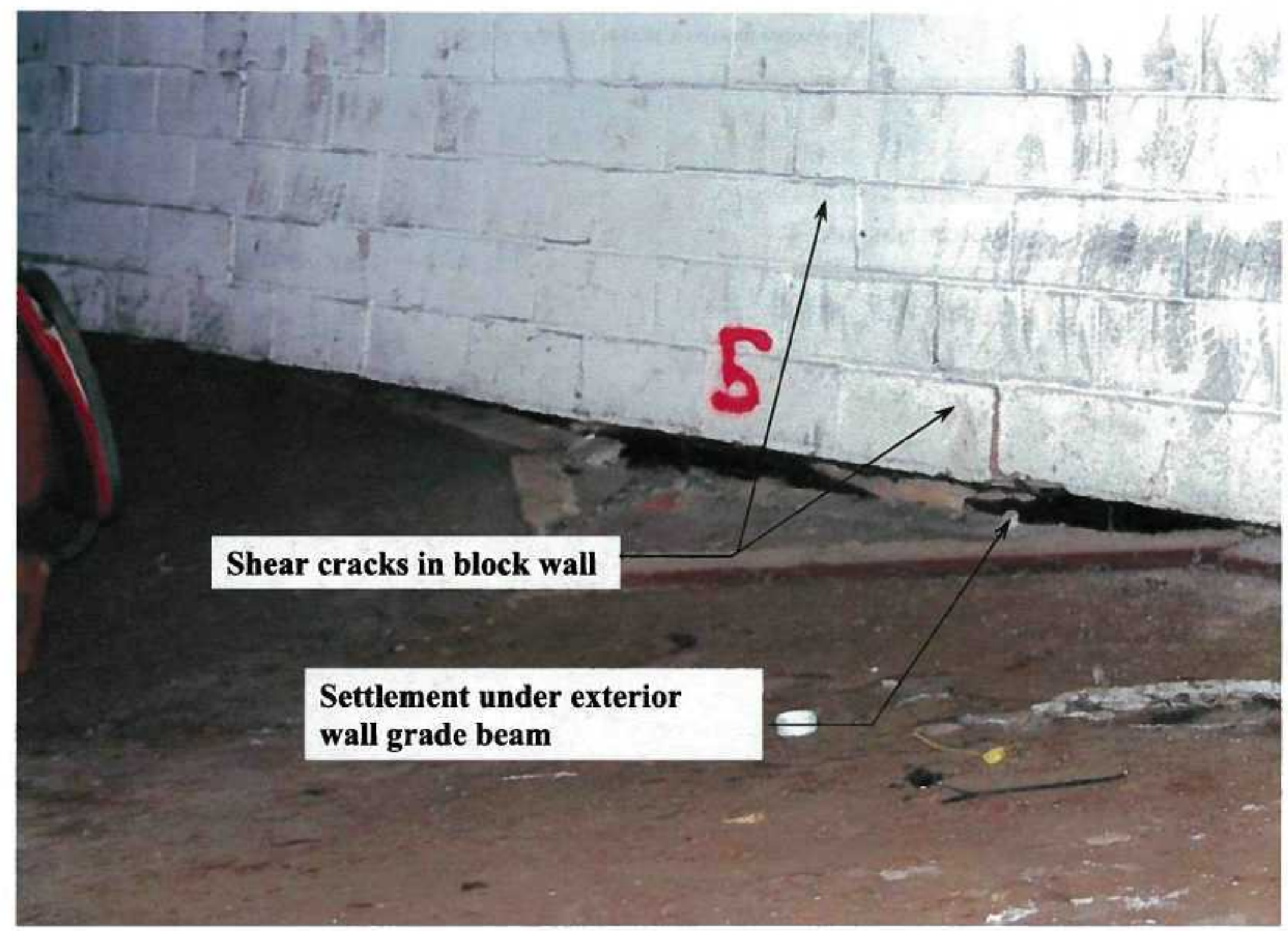

Fig. B-1. Photo of settlement under exterior wall grade beam. 


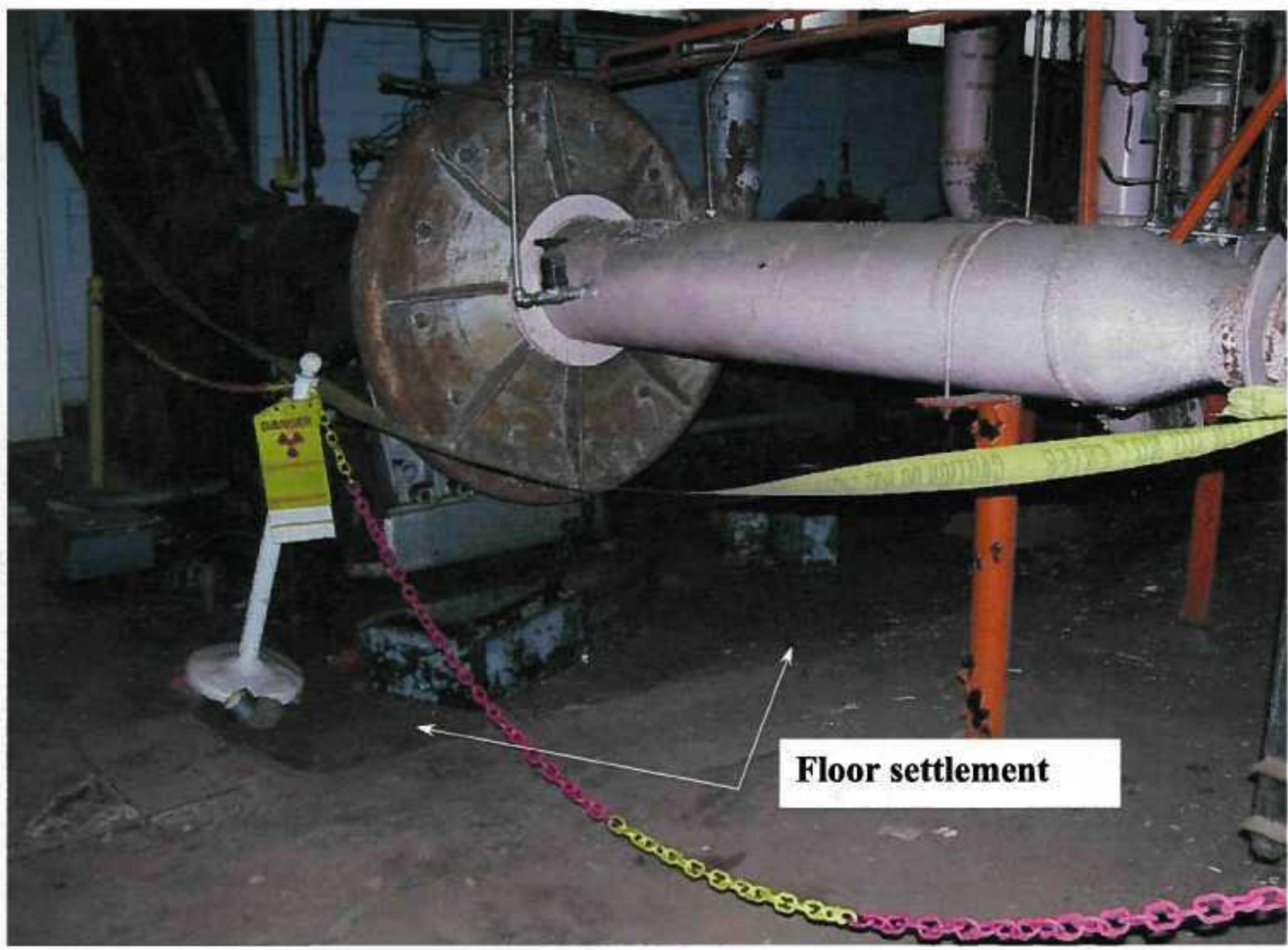

Fig. B-2. Photo of area of maximum settlement. 


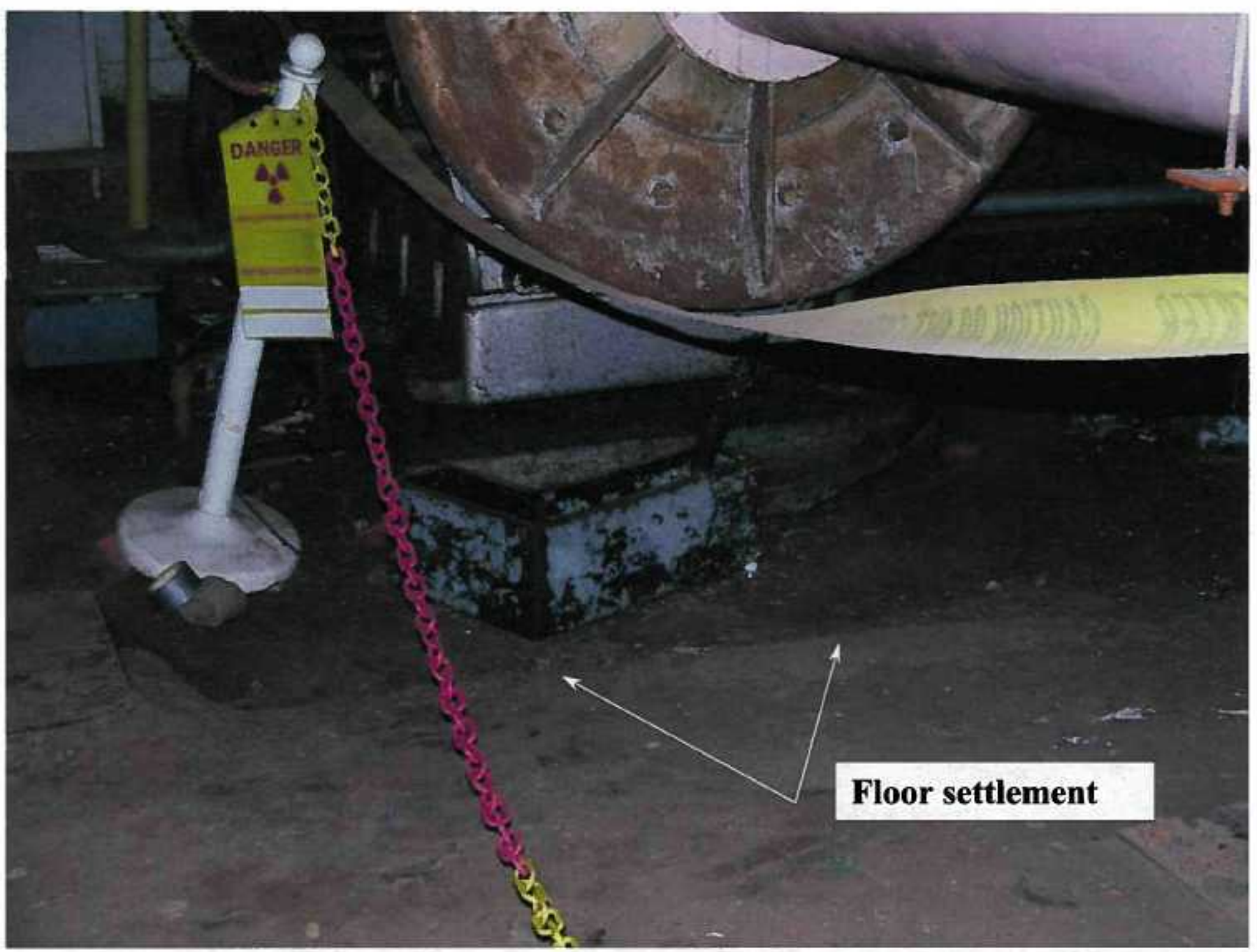

Fig. B-3. Photo of area of maximum settlement. 


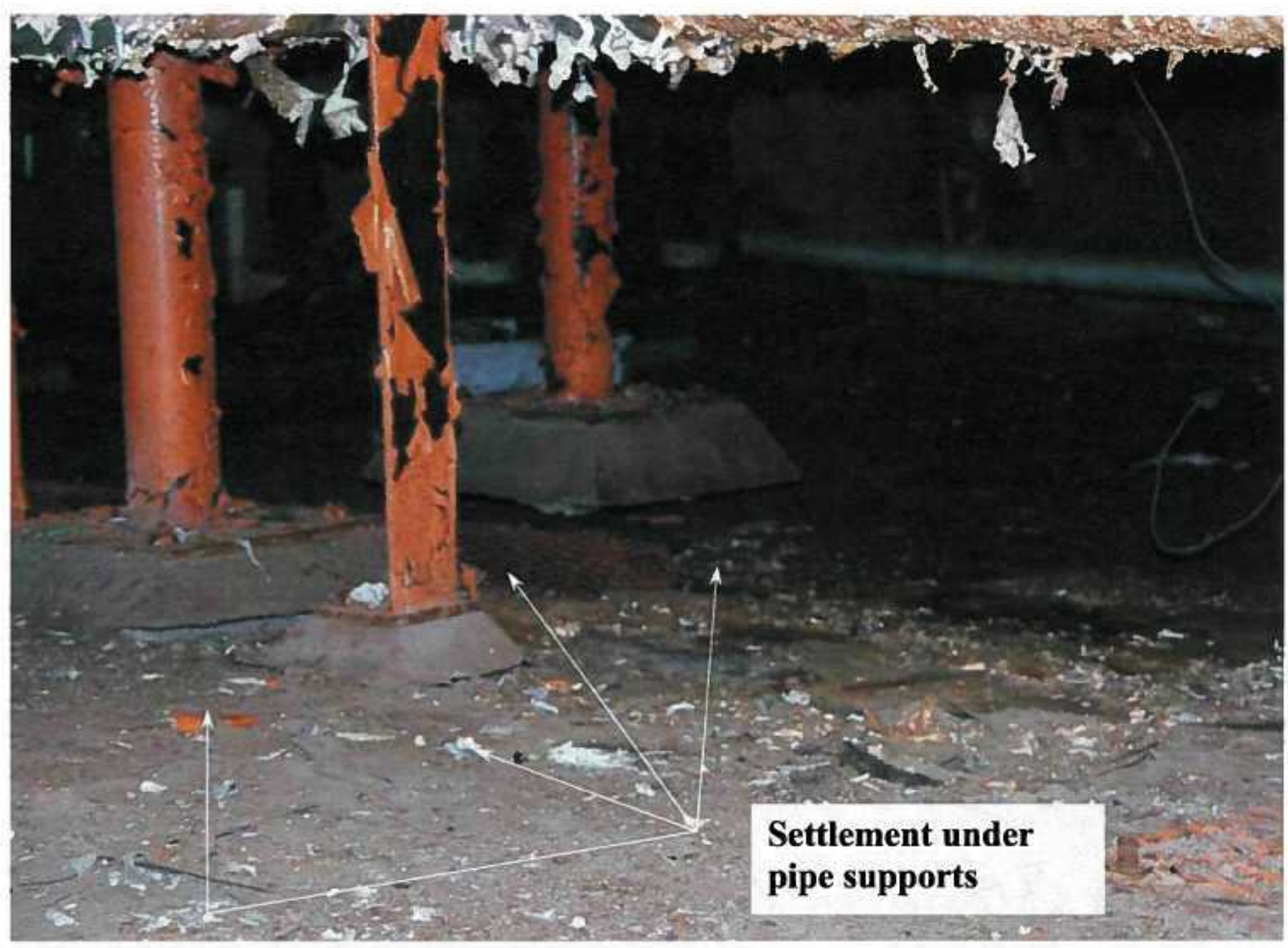

Fig. B-4. Photo of settlement under pipe supports. 


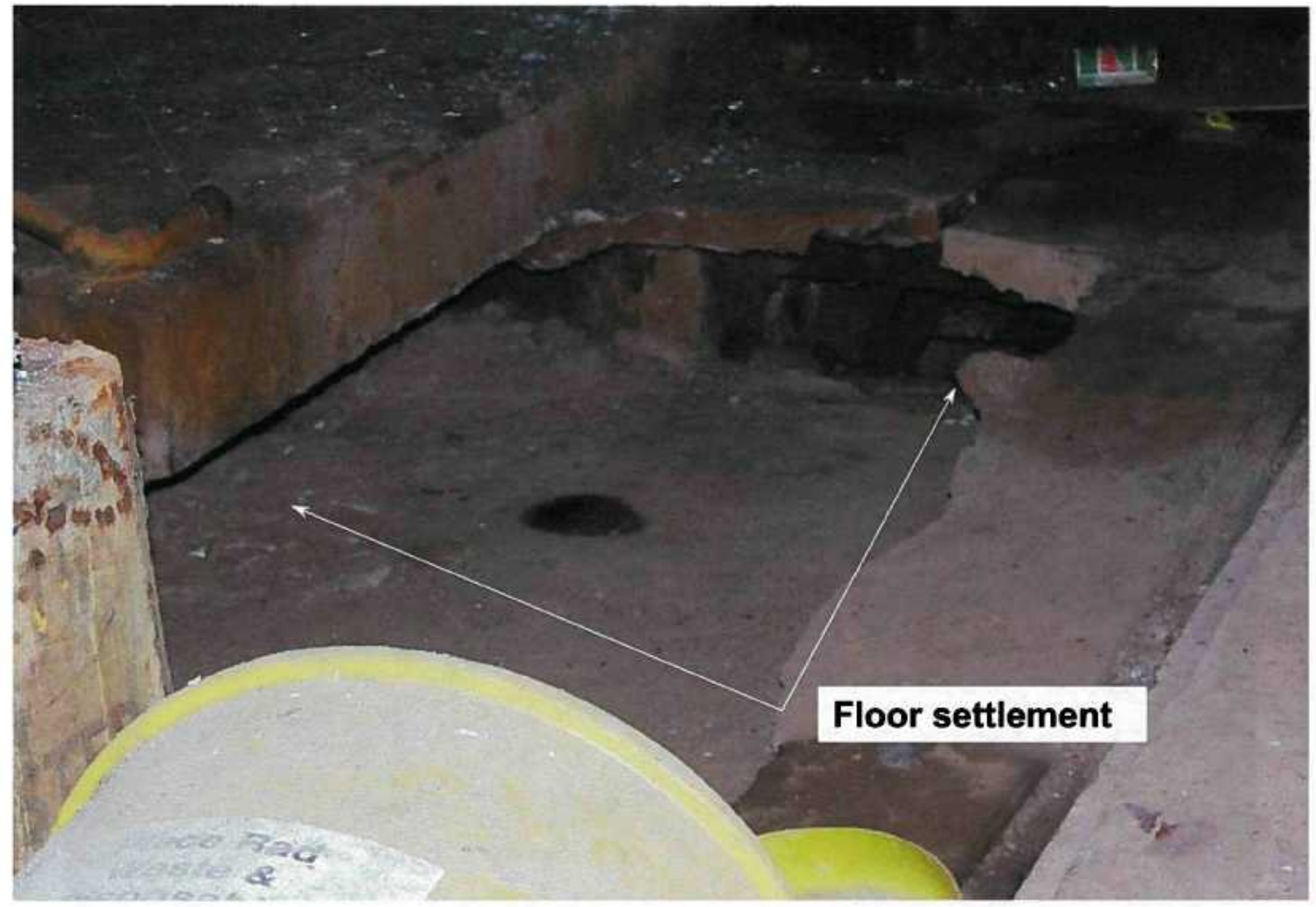

Fig. B-5. Photo of area of floor slab separation. 


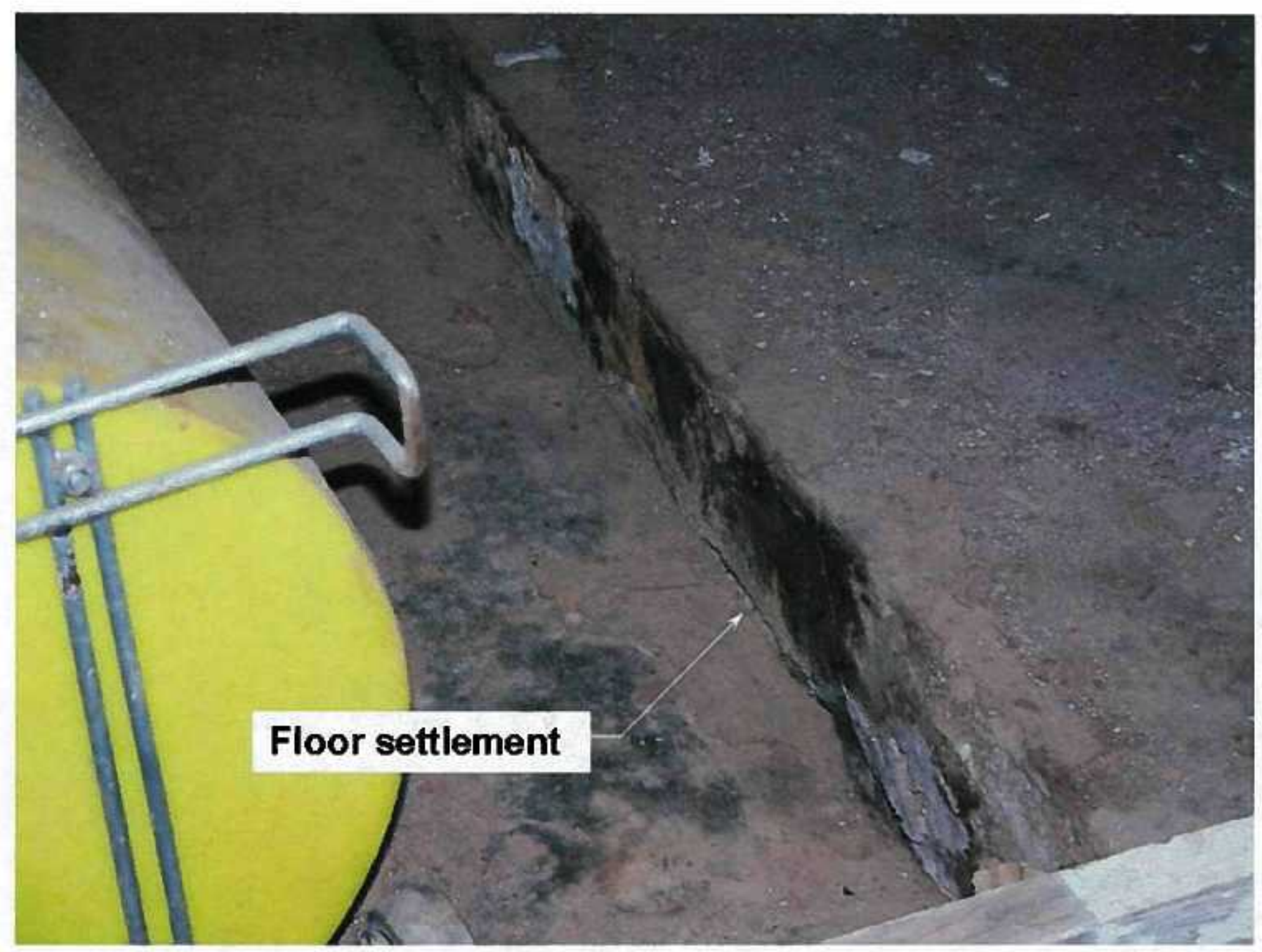

Fig. B-6. Photo of area of floor slab settlement. 


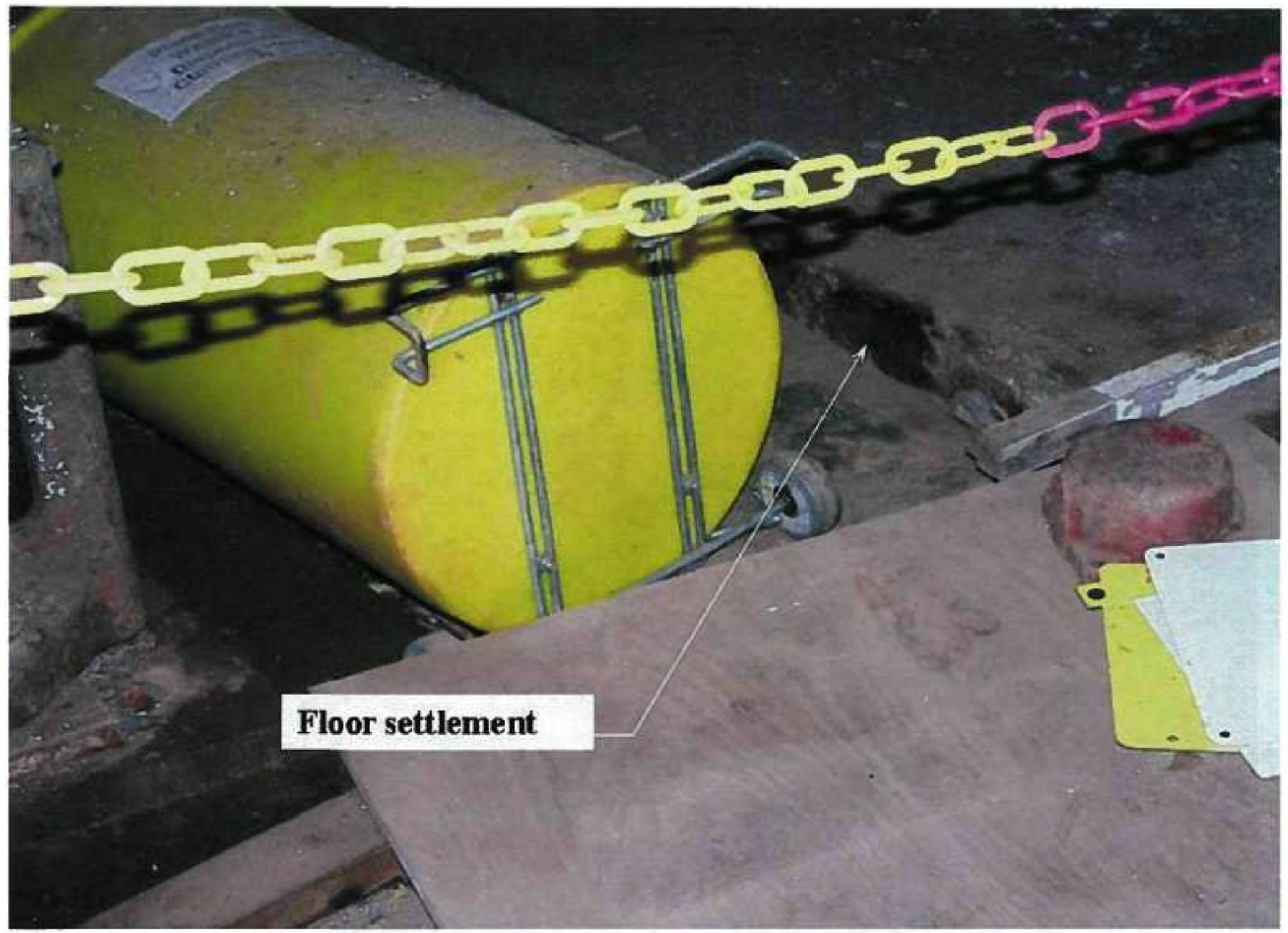

Fig. B-7. Photo of area of floor slab settlement. 


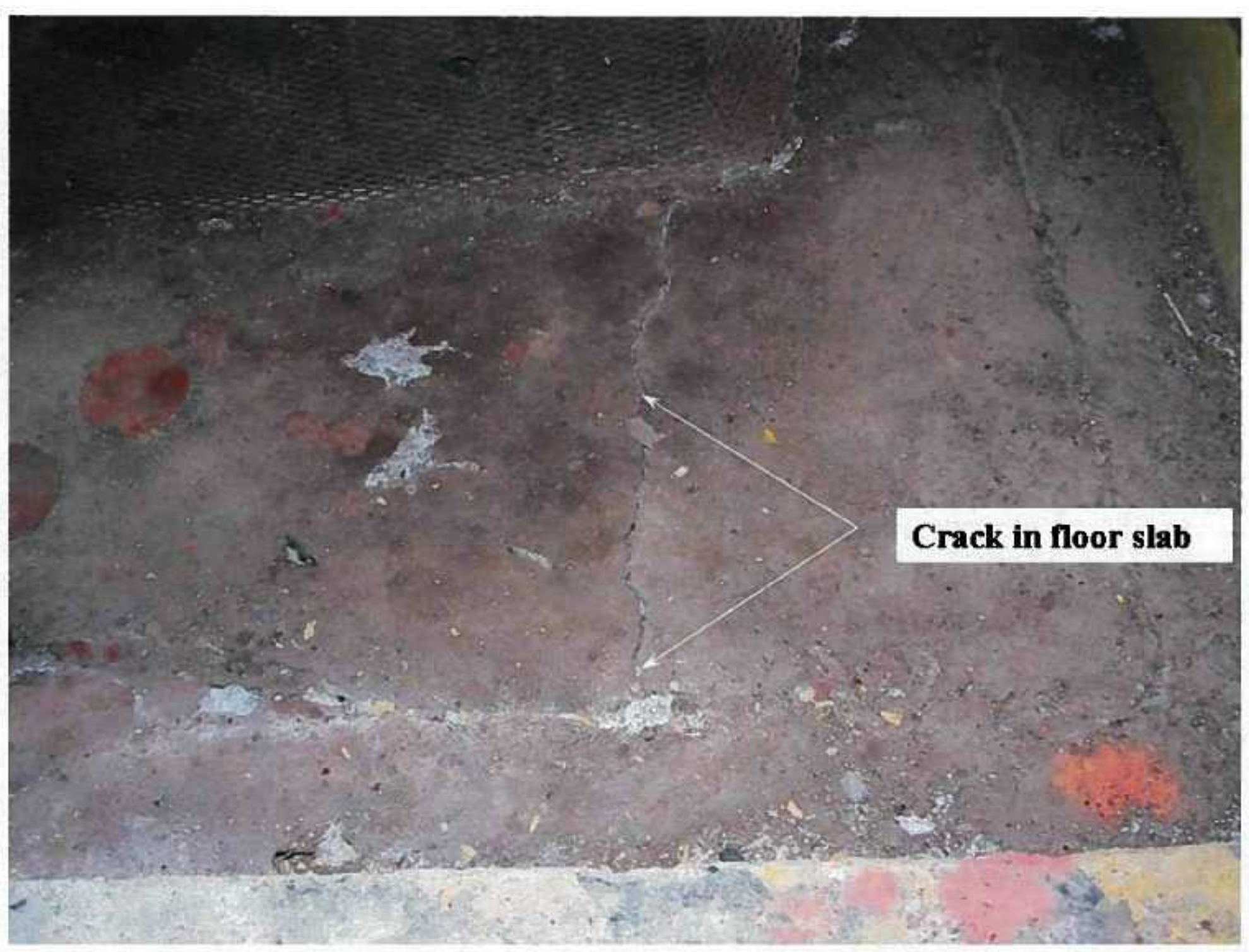

Fig. B-8. Photo of example of settlement crack in floor slab. 


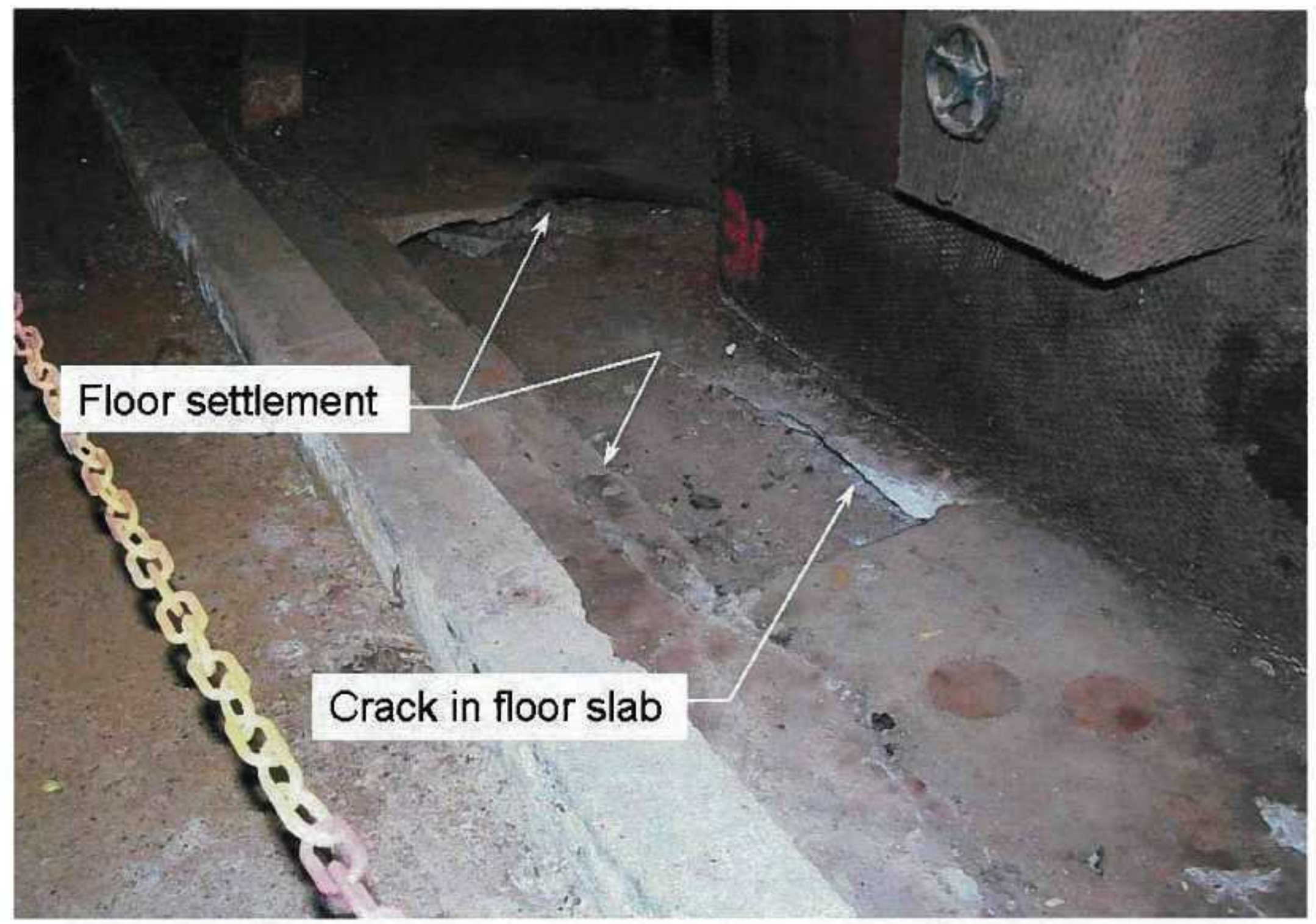

Fig. B-9. Photo of area of noor slab separation. 


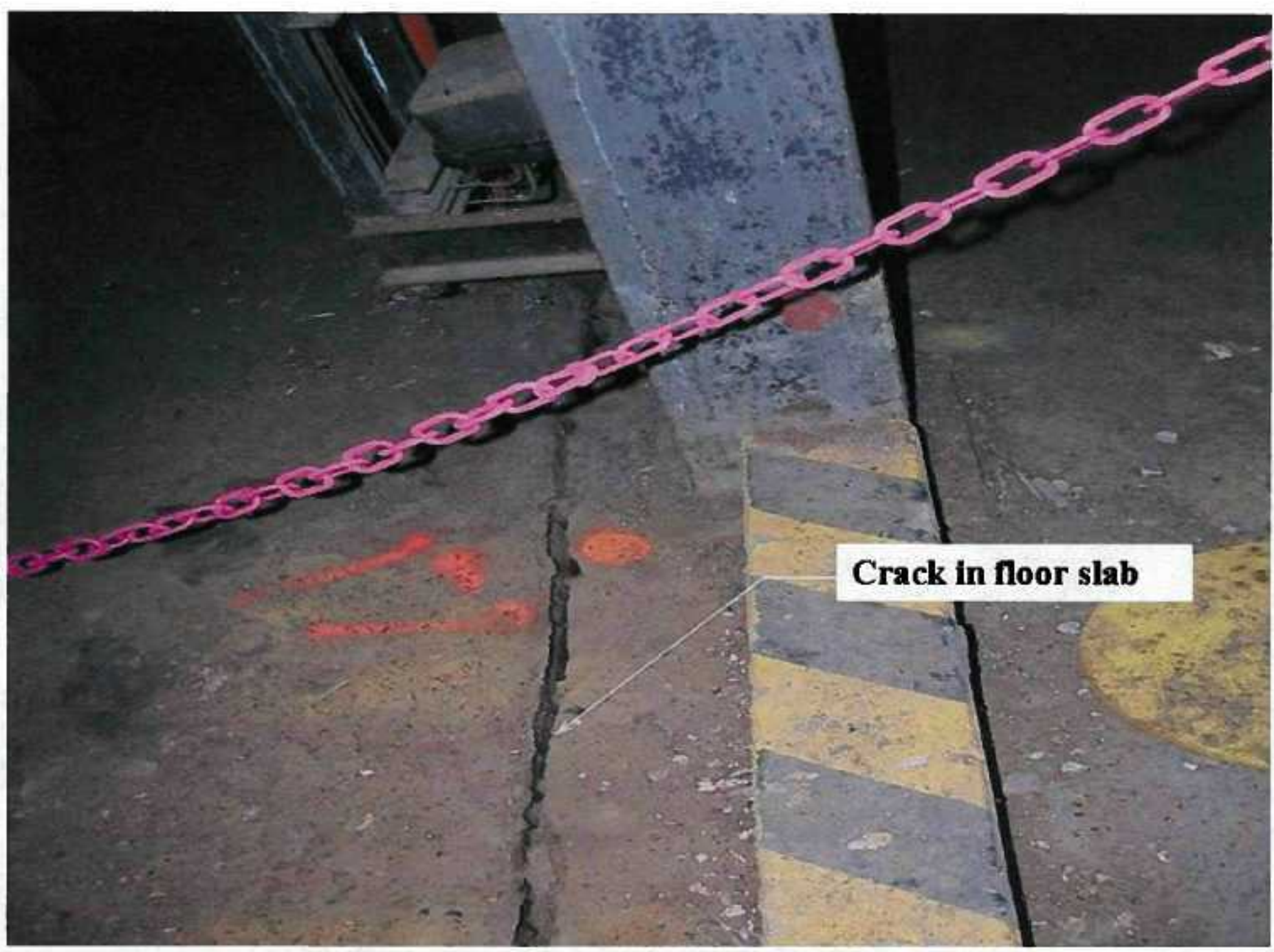

Fig. B-10. Photo of example of floor slab crack. 


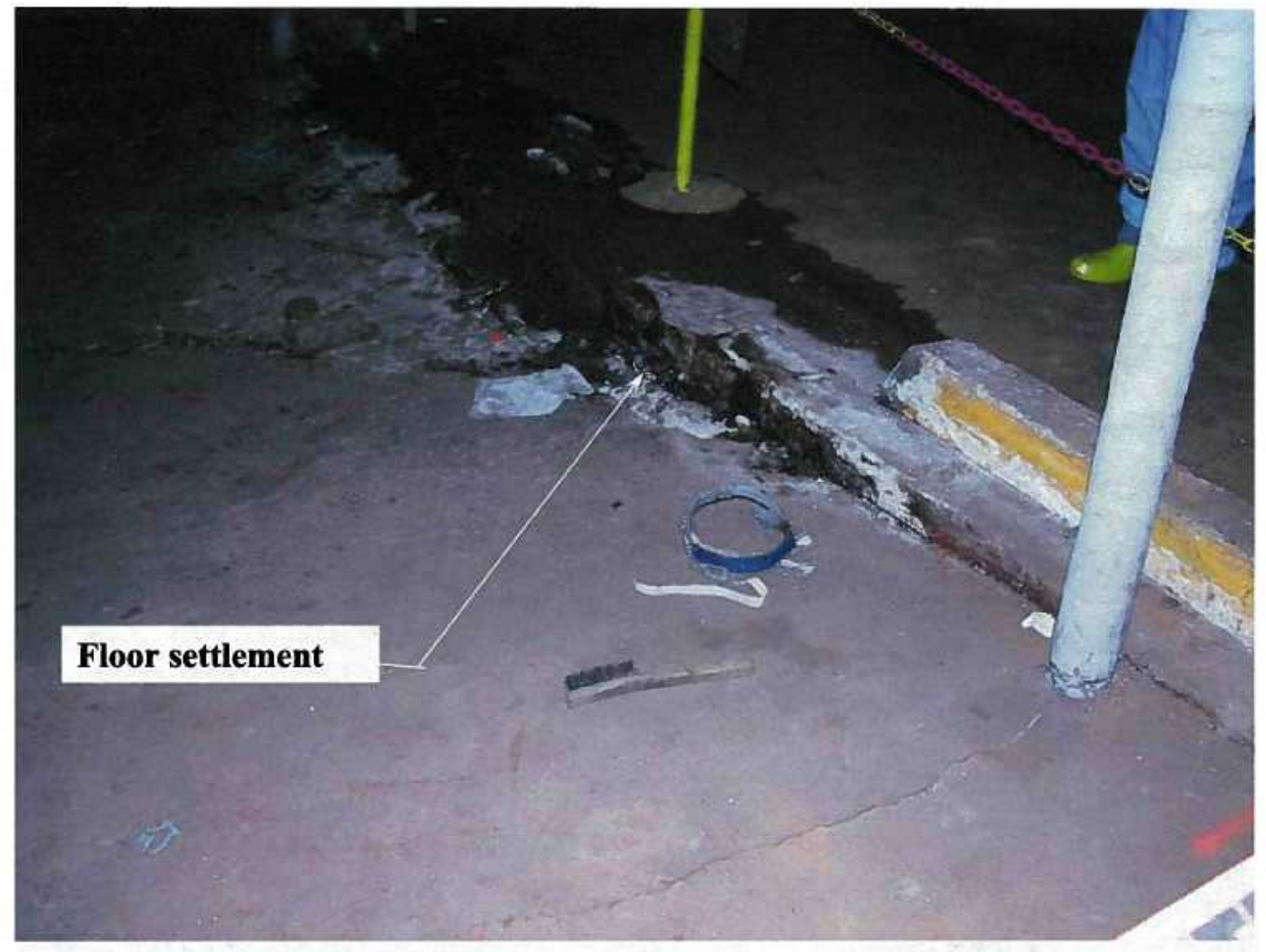

Fig. B-11. Photo of area floor settlement. 


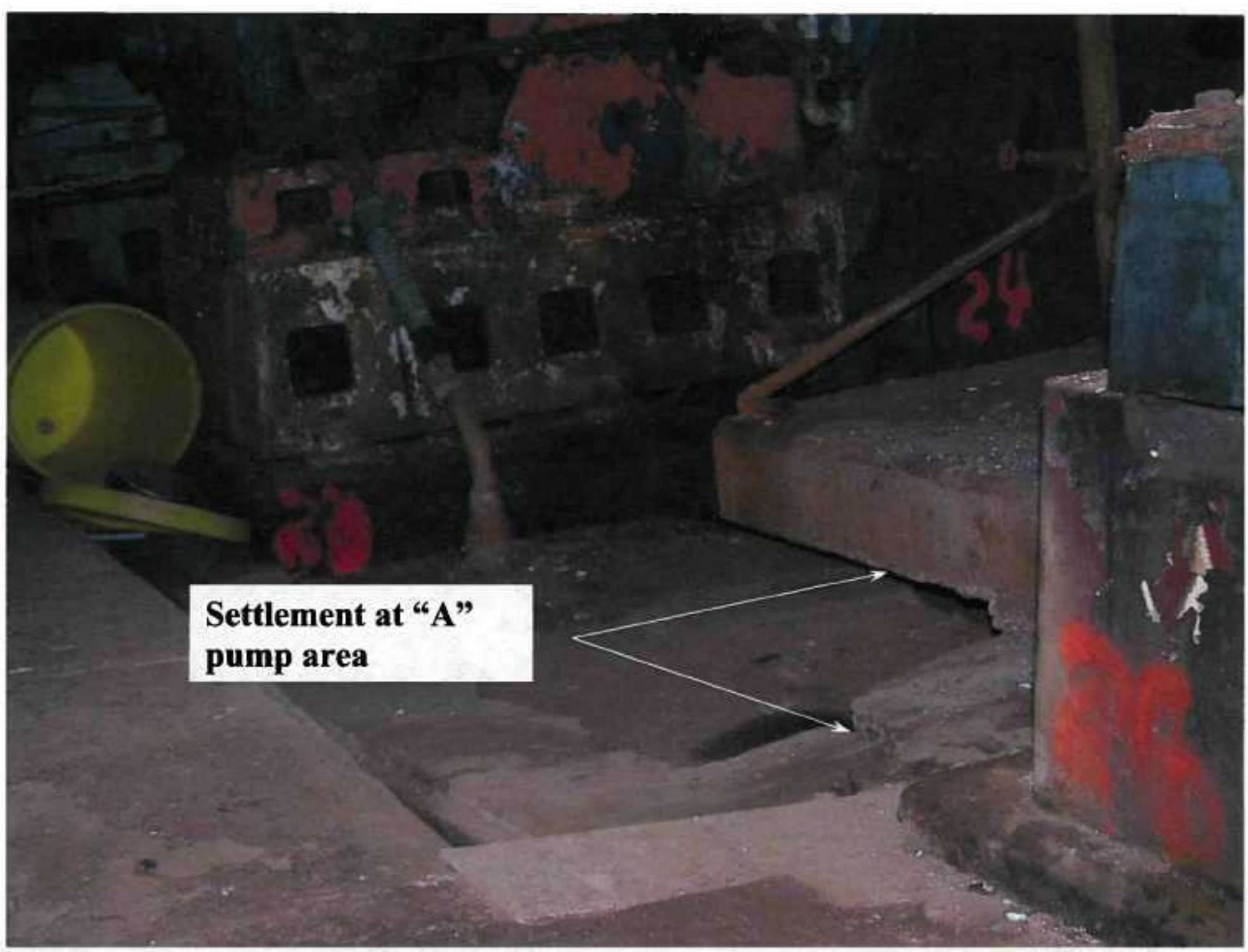

Fig. B-12. Photo of pump area settlement. 


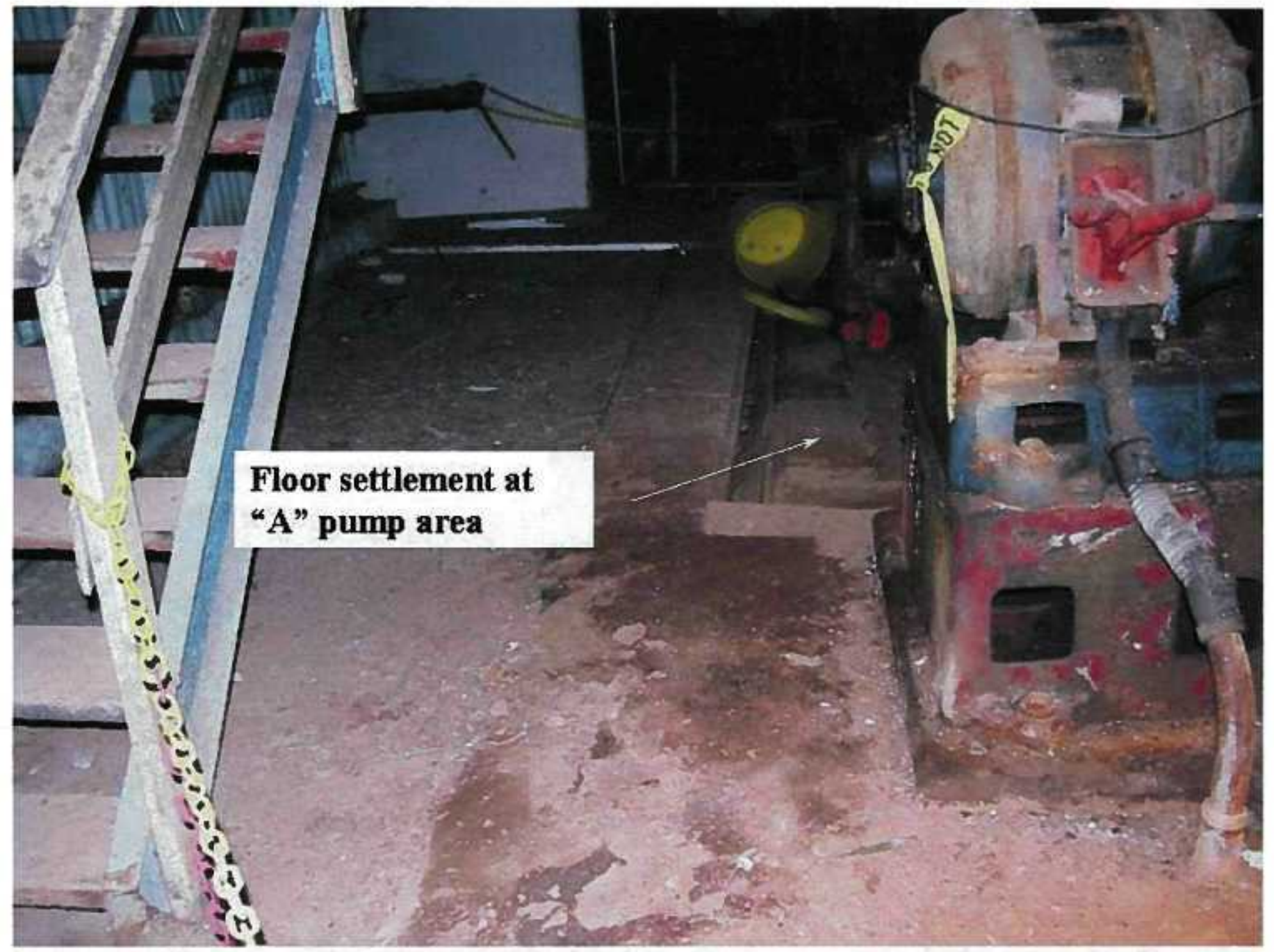

Fig. B-13. Photo of settlement at "A" pump area. 


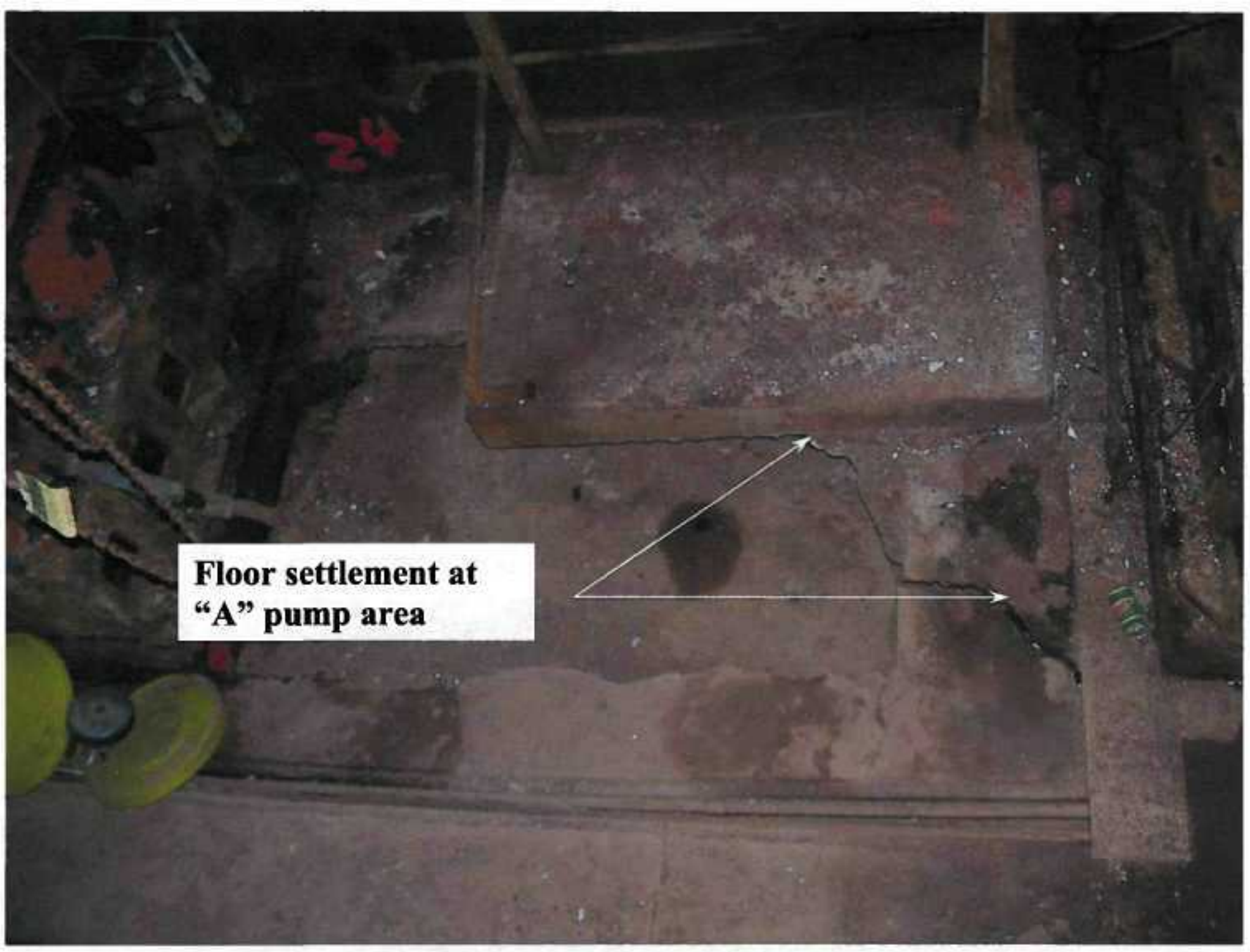

Fig. B-14. Photo of floor settlement at "A" pump area. 


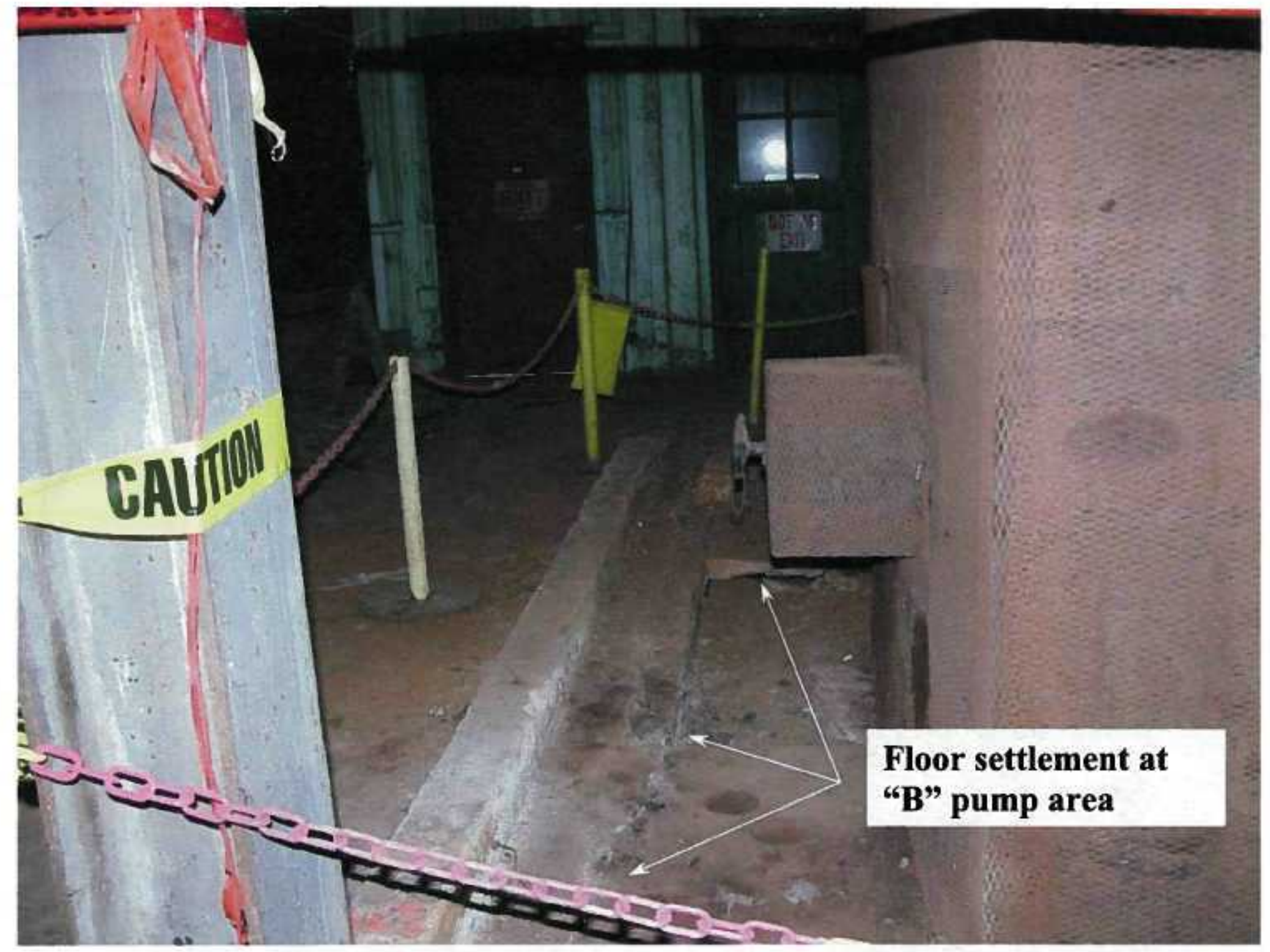

Fig. B-15. Photo of floor settlement at "B" pump area. 


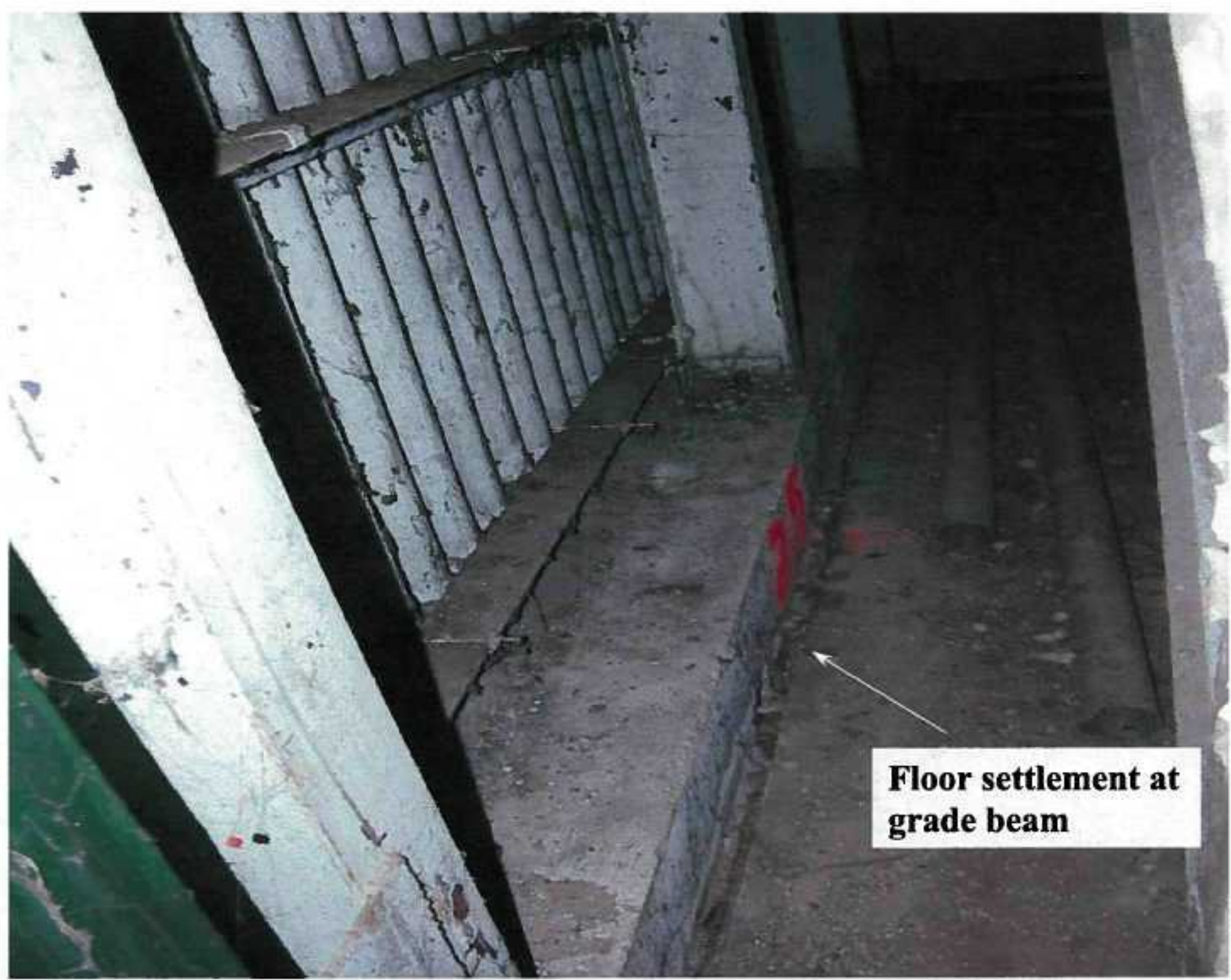

Fig. B-16. Photo of floor settlement at grade beam. 


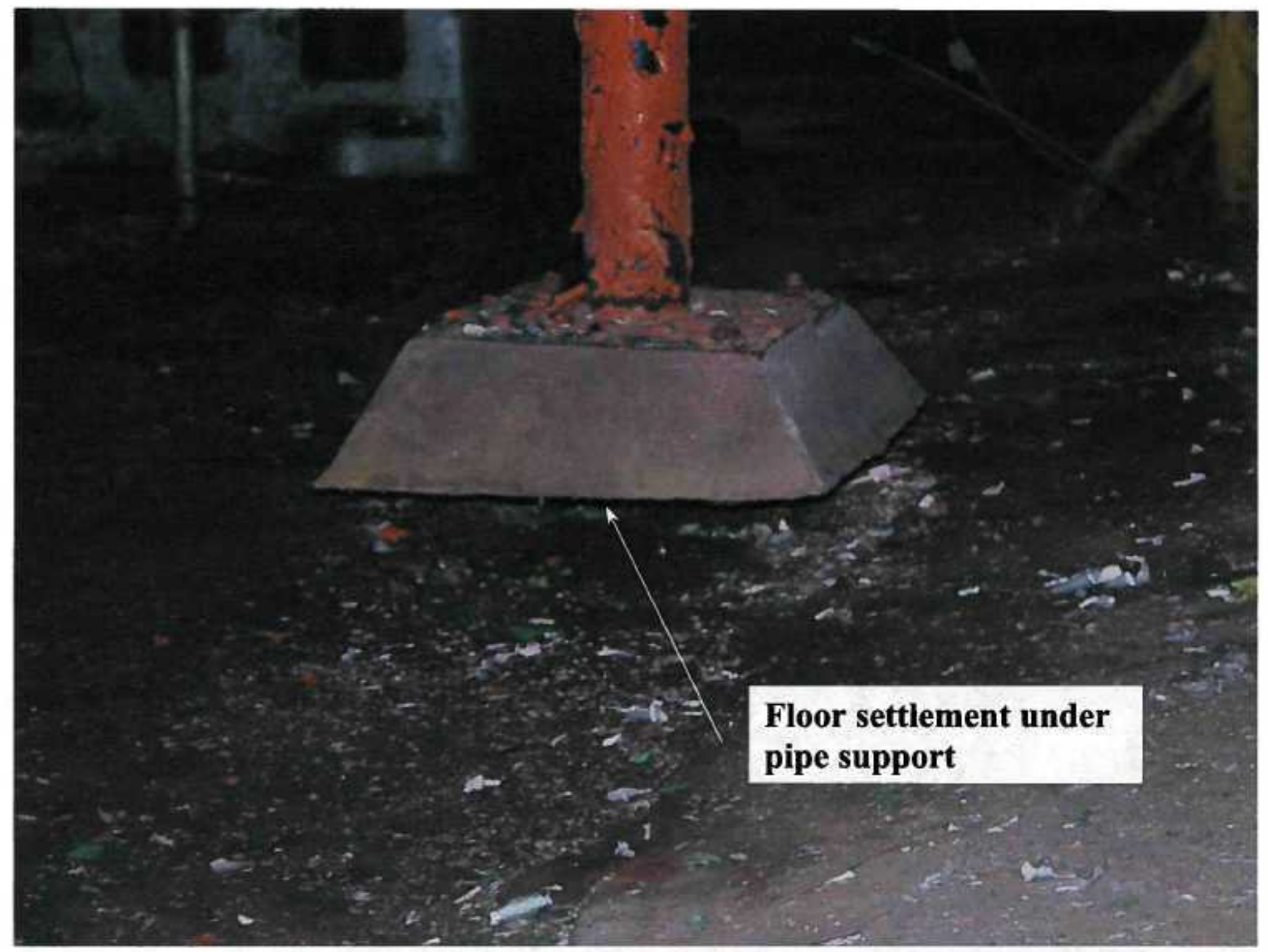

Fig. B-17. Photo of floor settlement under pipe support. 


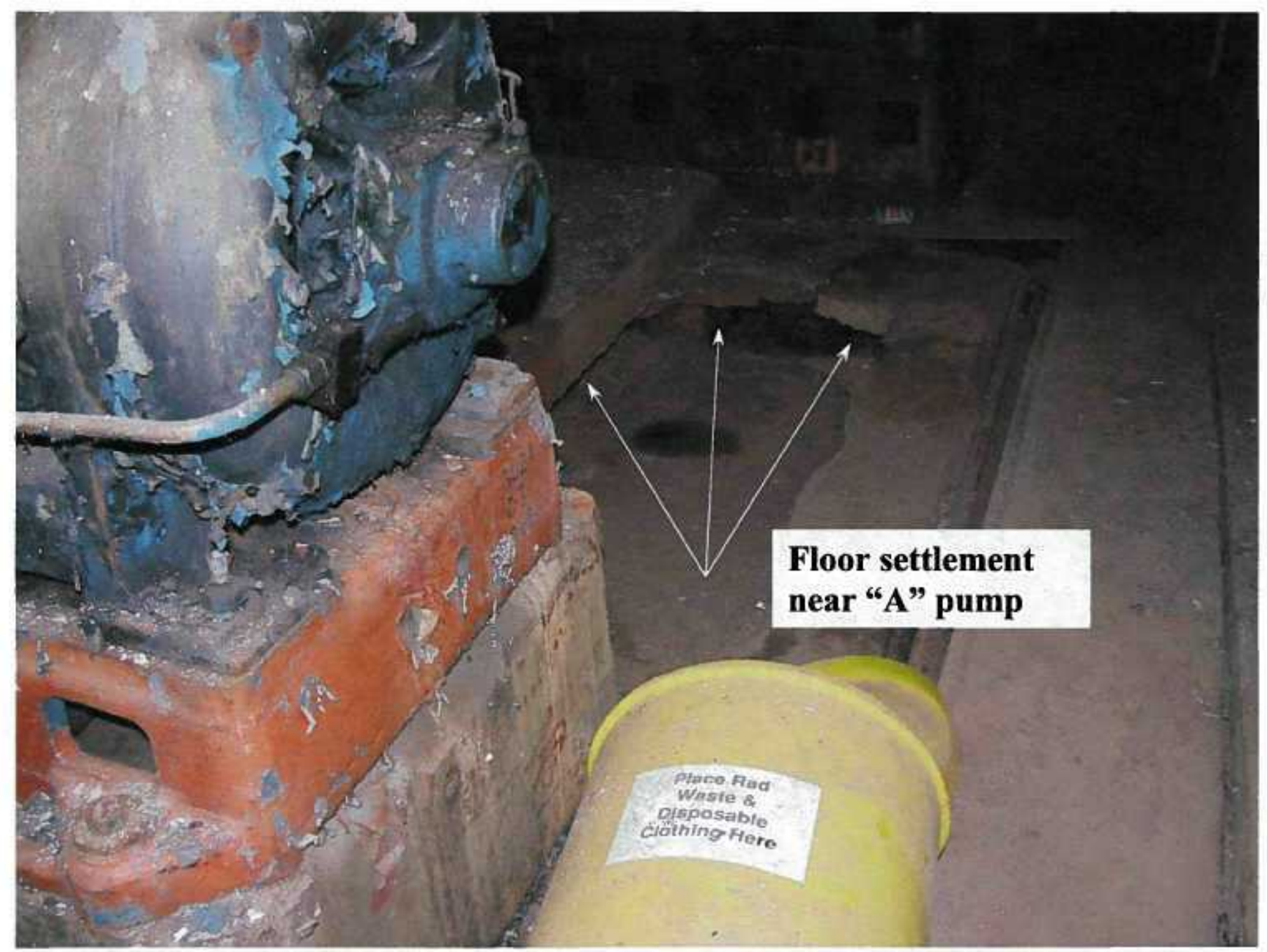

Fig. B-18. Photo of pump "A" area floor settlement. 


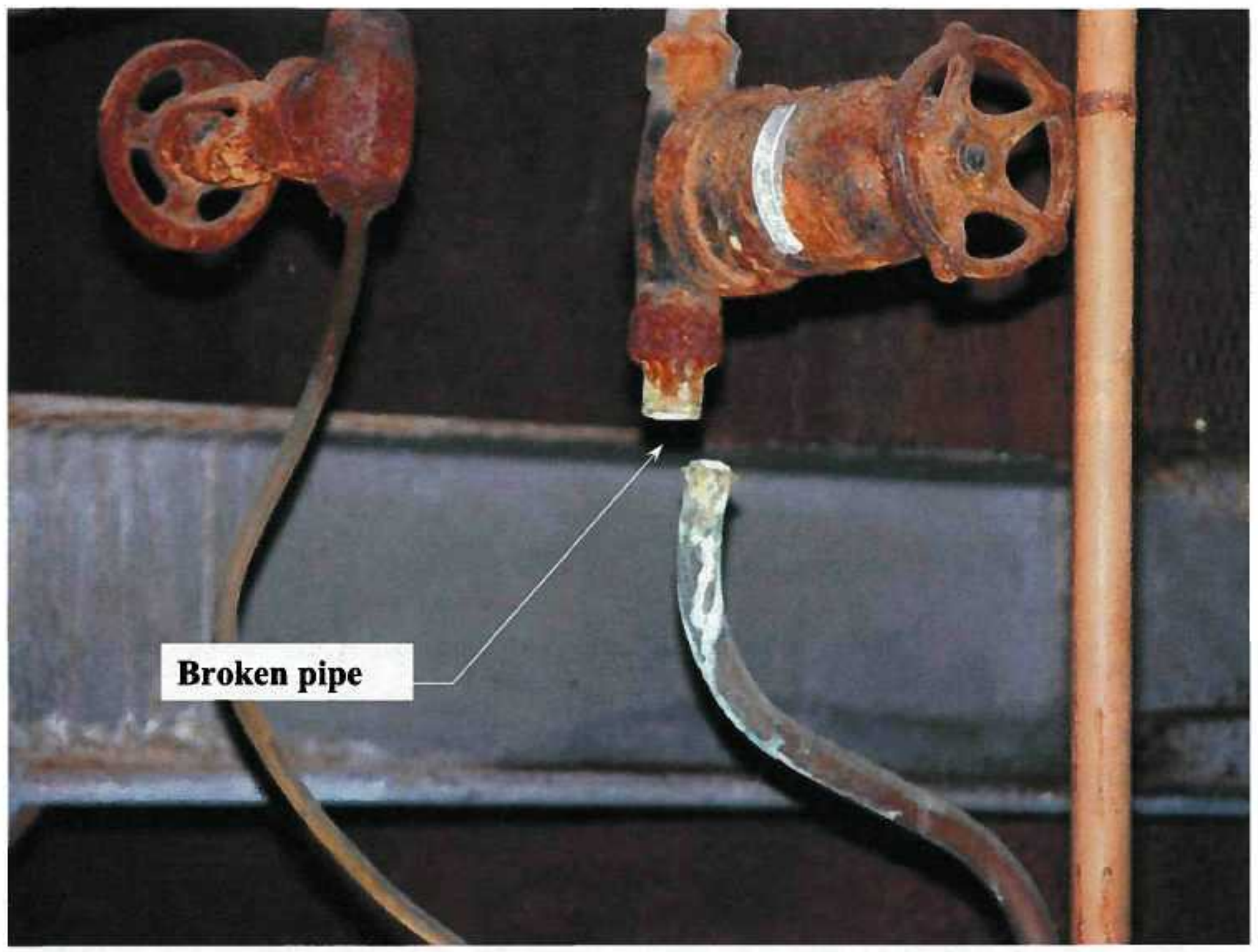

Fig. B-19. Photo of broken pipe. 


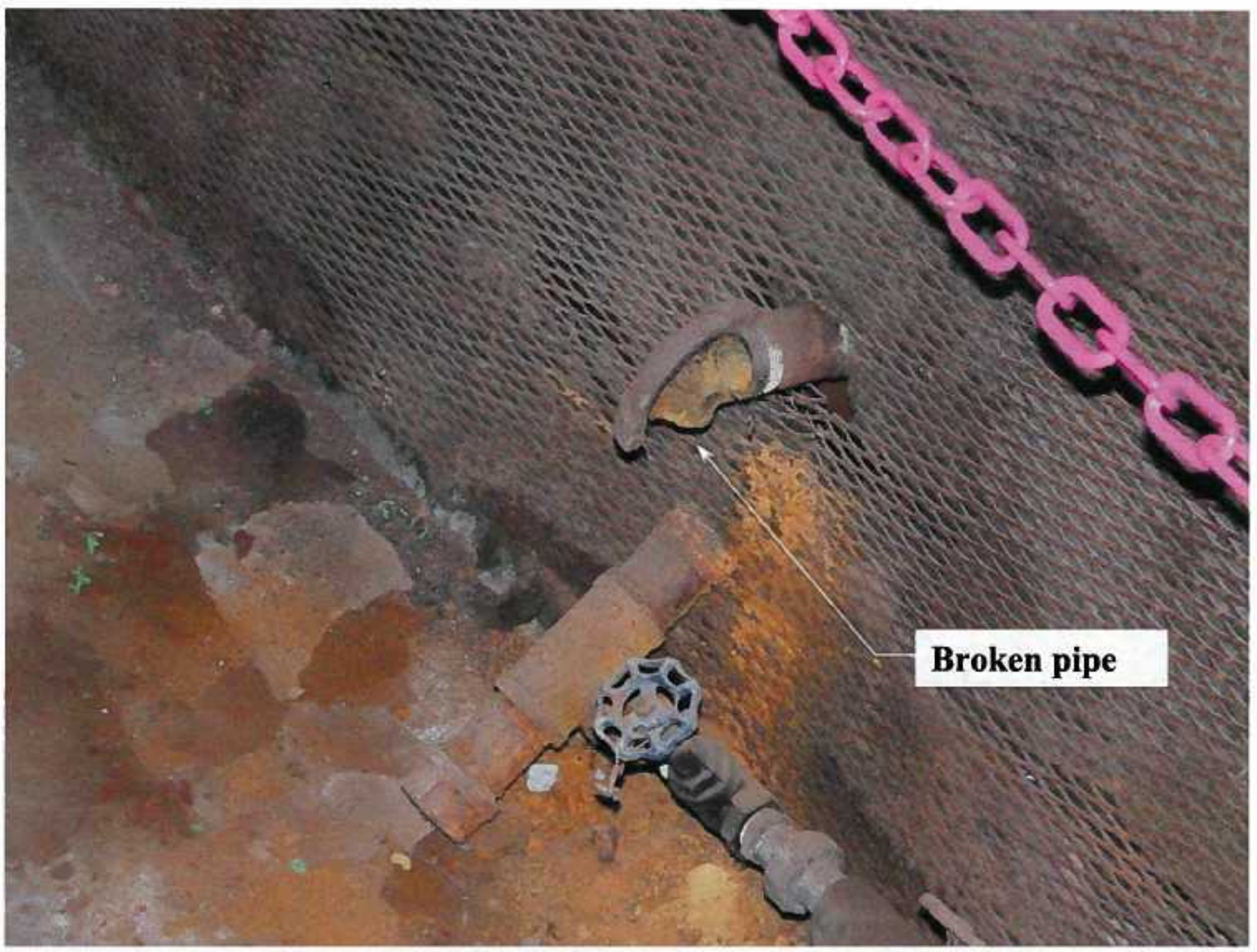

Fig. B-20. Photo of example of broken pipe. 


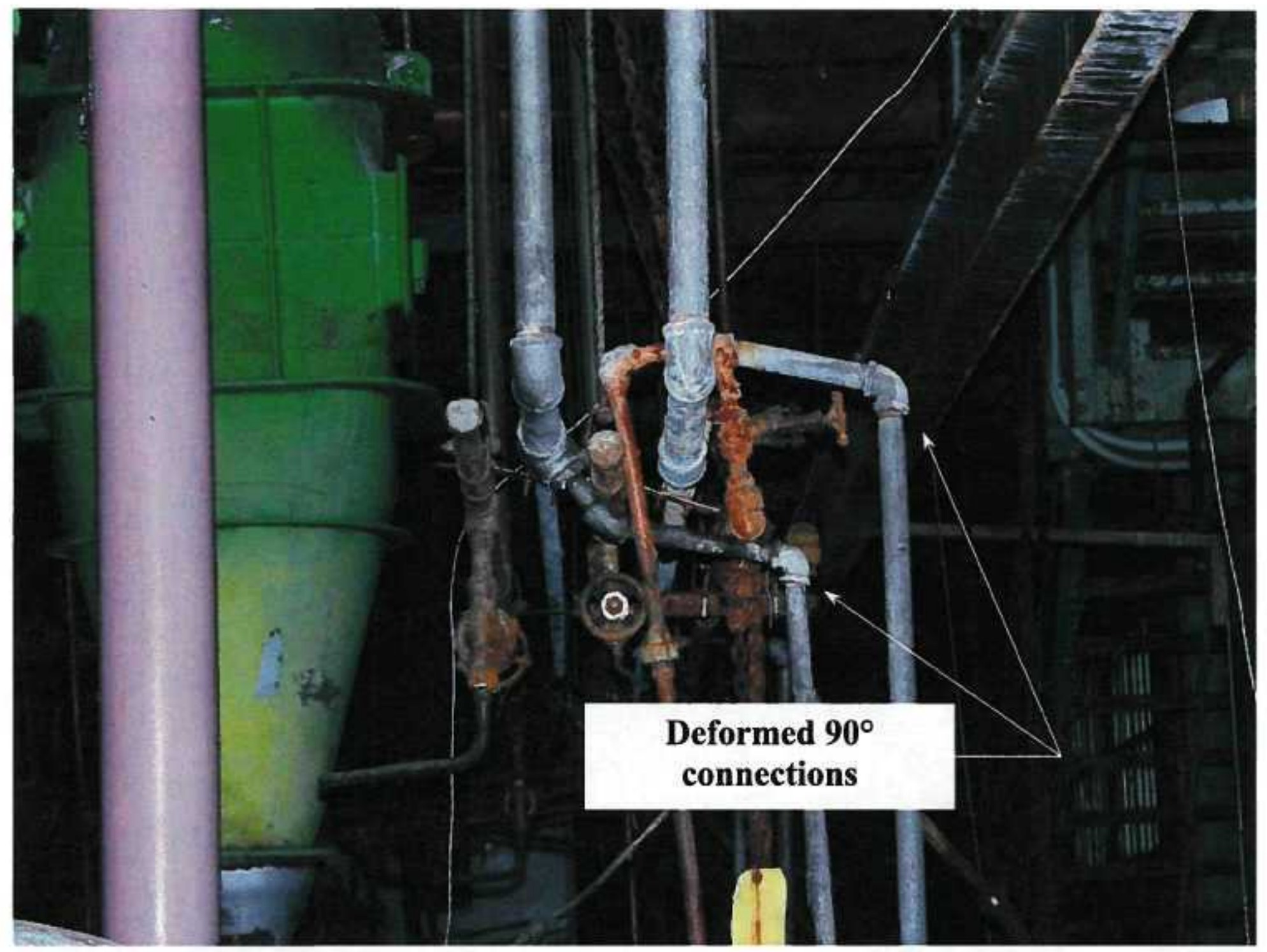

Fig. B-21. Photo of deformed 90-degree connections. 


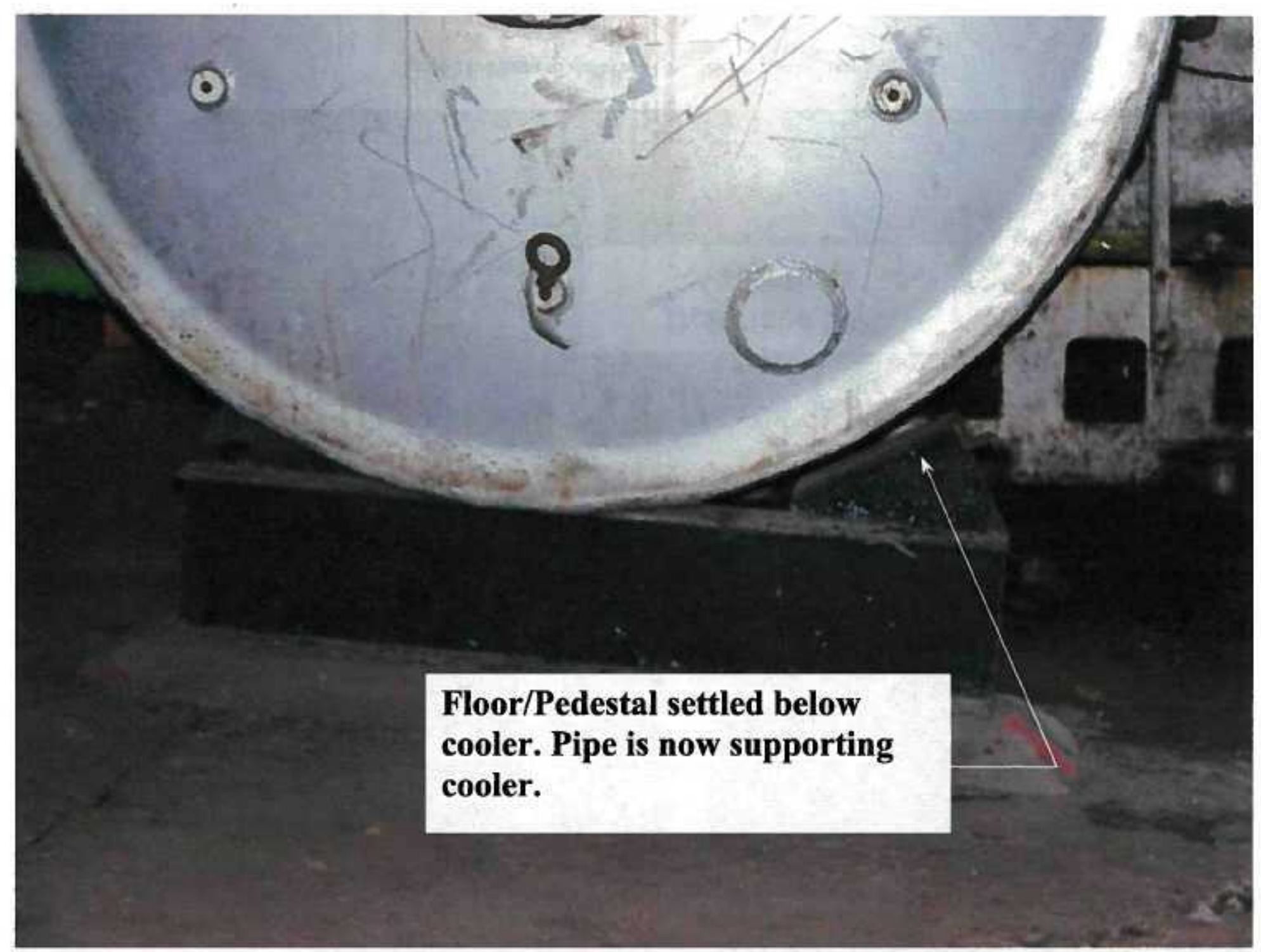

Fig. B-22. Photo of floor settlement below cooler. 


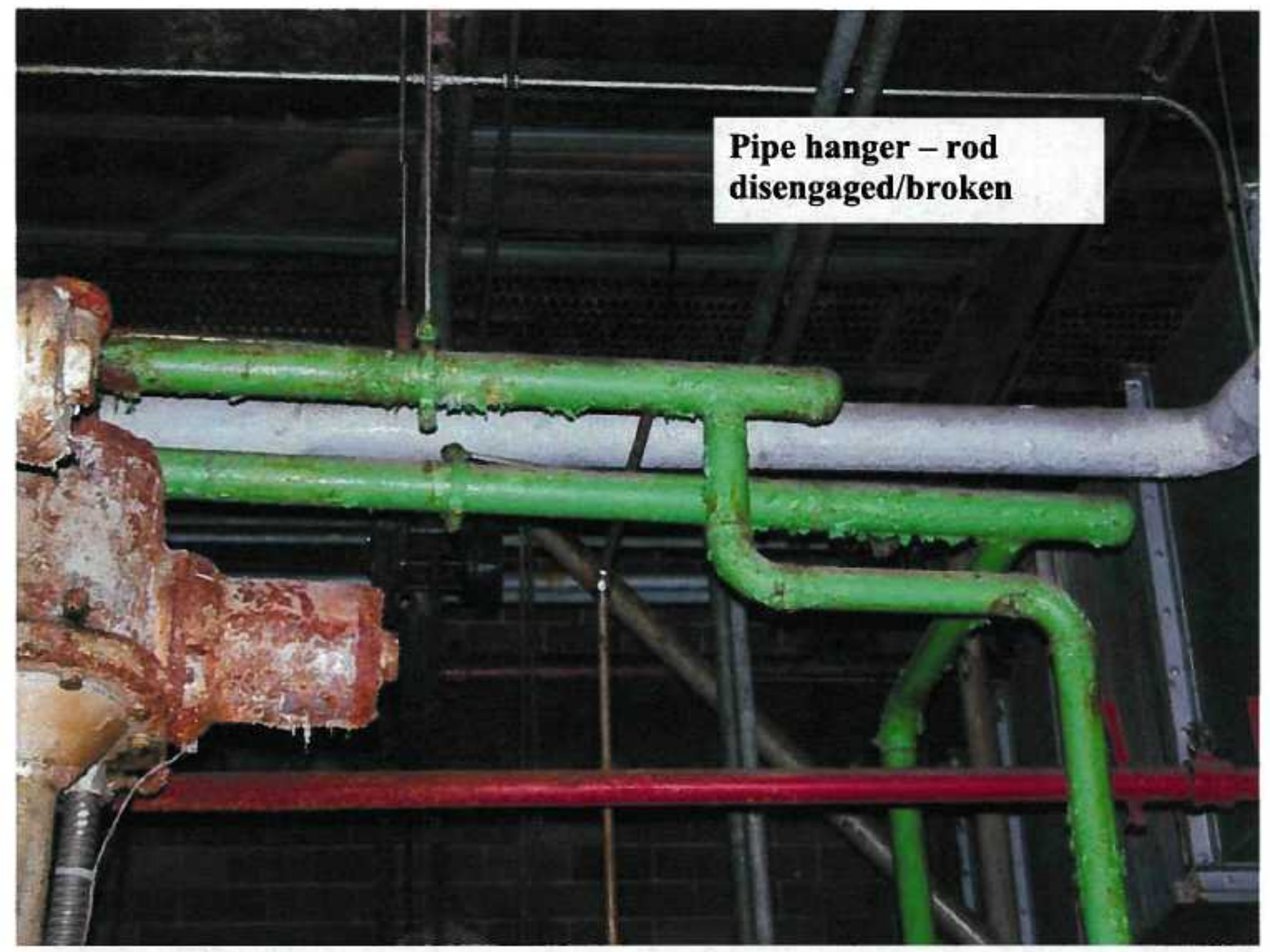

Fig. B-23. Photo of example of broken pipe support. 


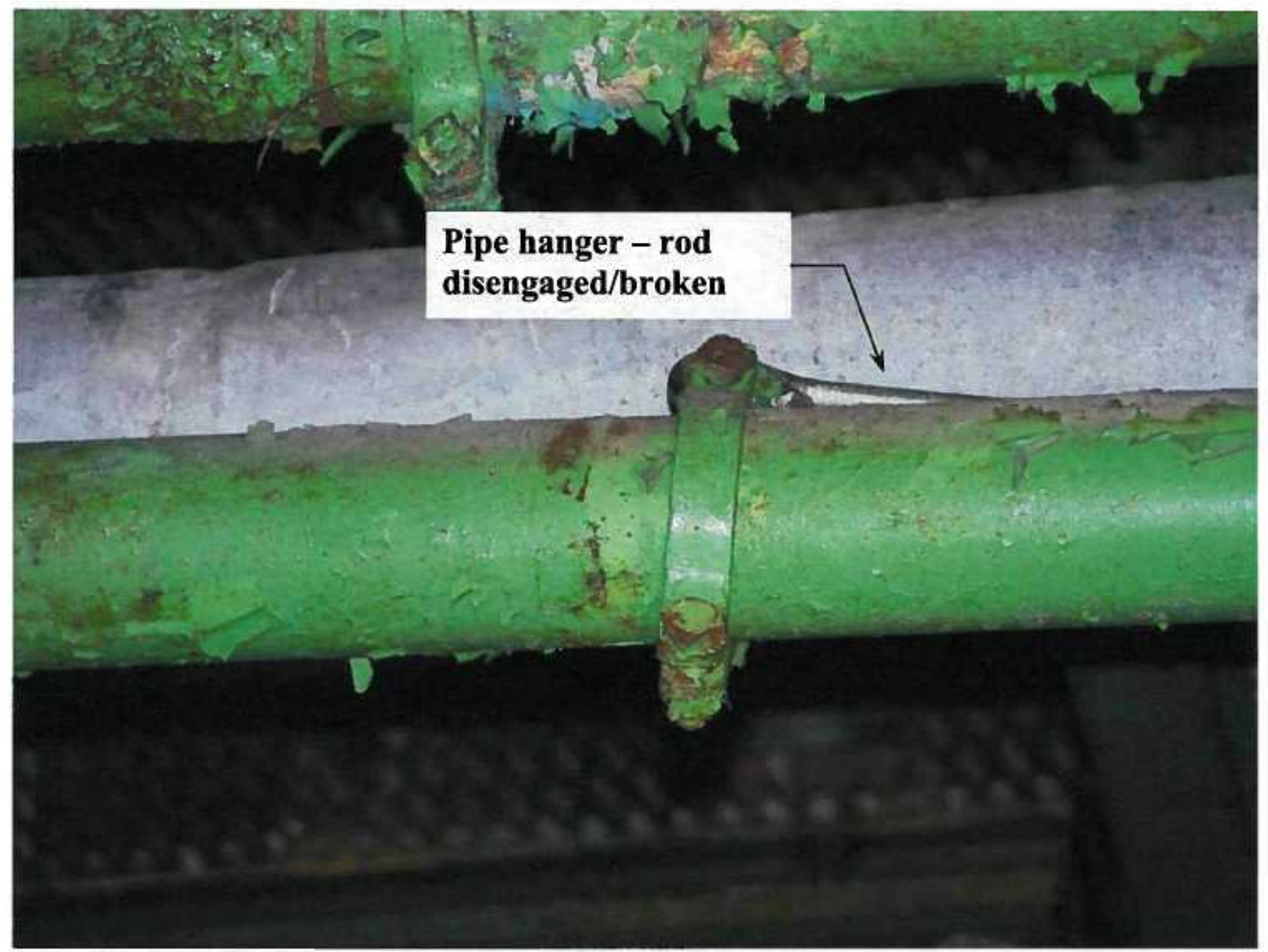

Fig. B-24. Photo of broken pipe support. 


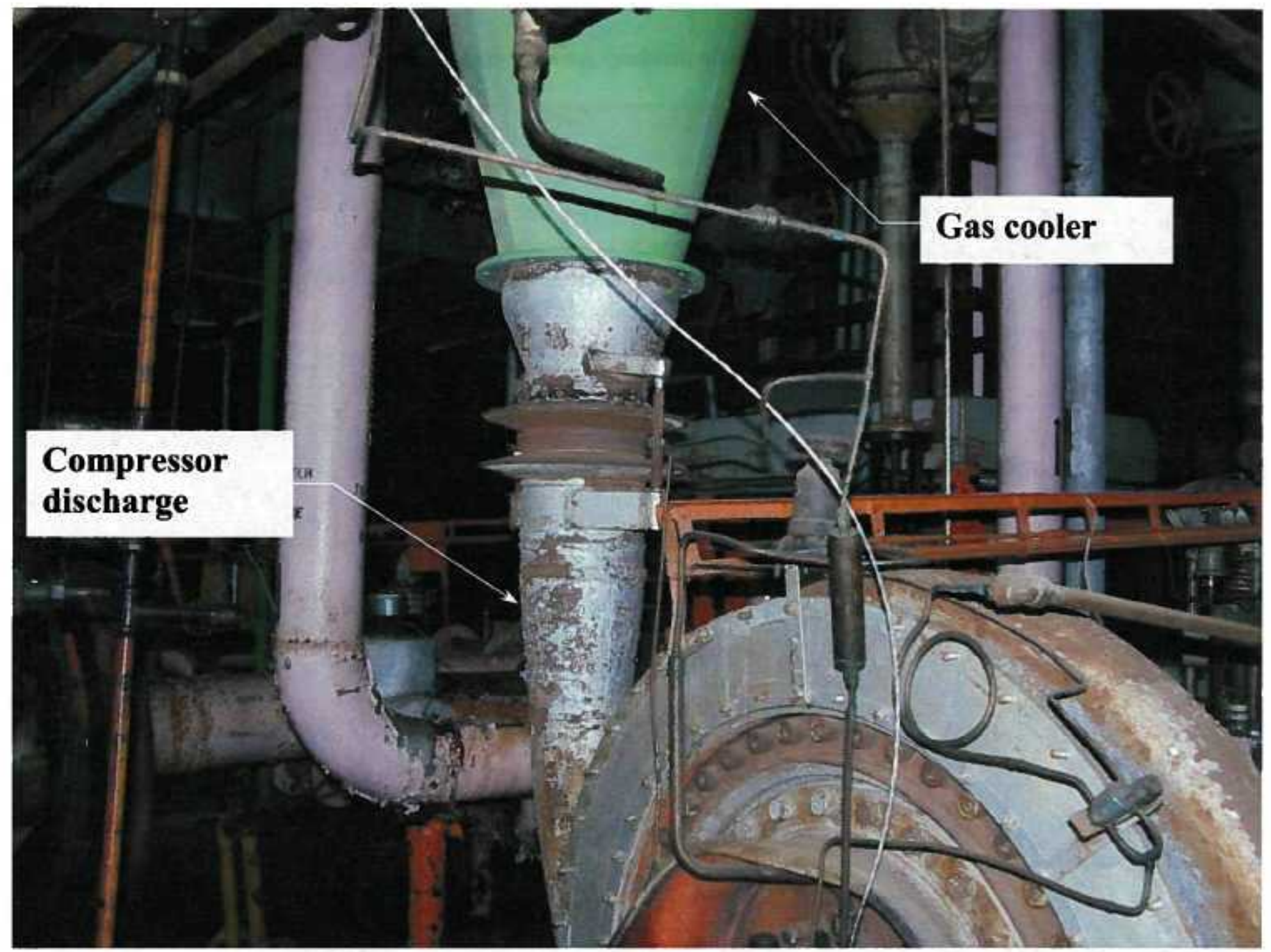

Fig. B-25. Photo of gas cooler area. 


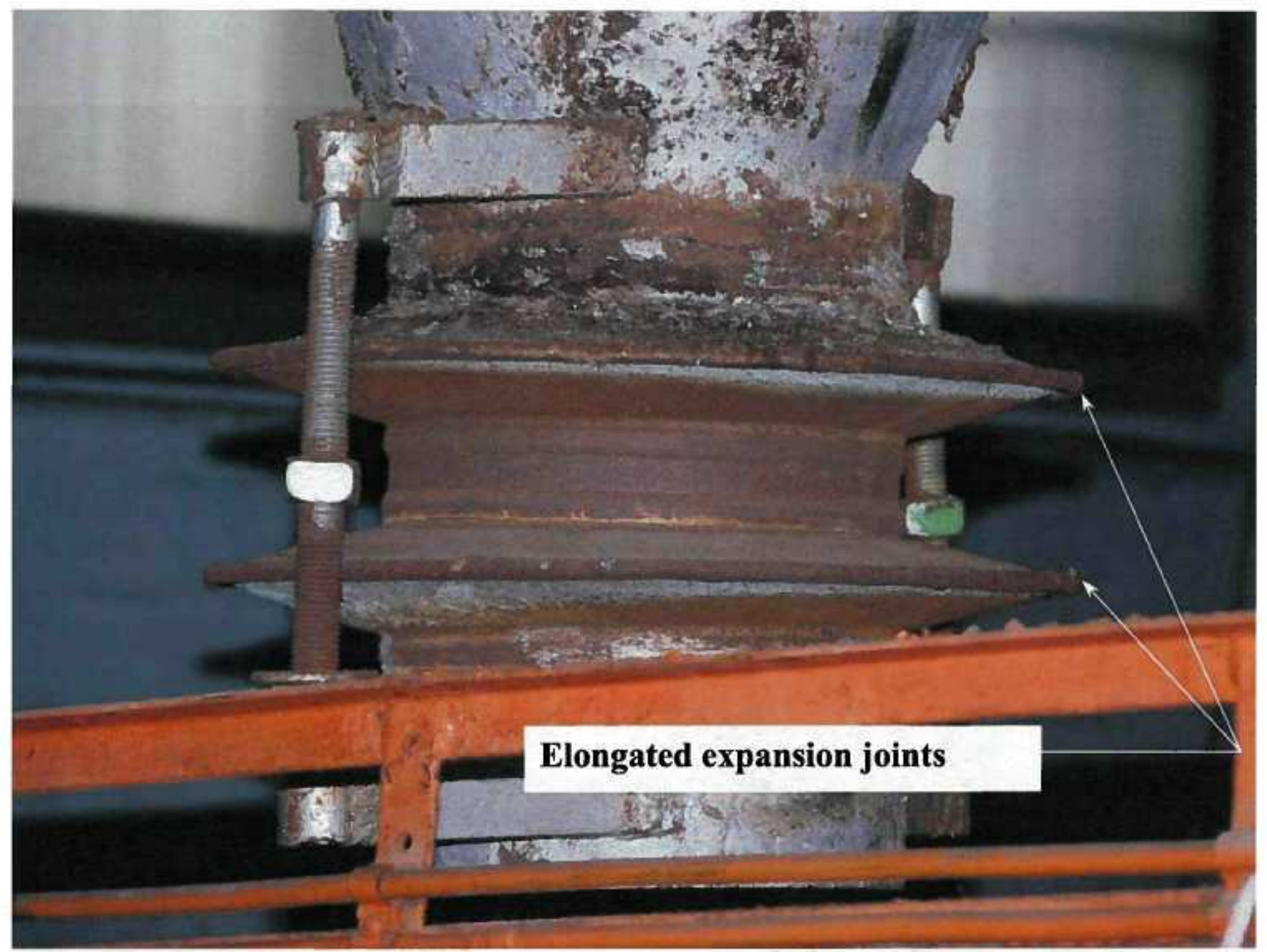

Fig. B-26. Photo of elongated expansion joints. 
APPENDIX C.

FIELD REPORTS FROM ATI REPORT IN 2003 


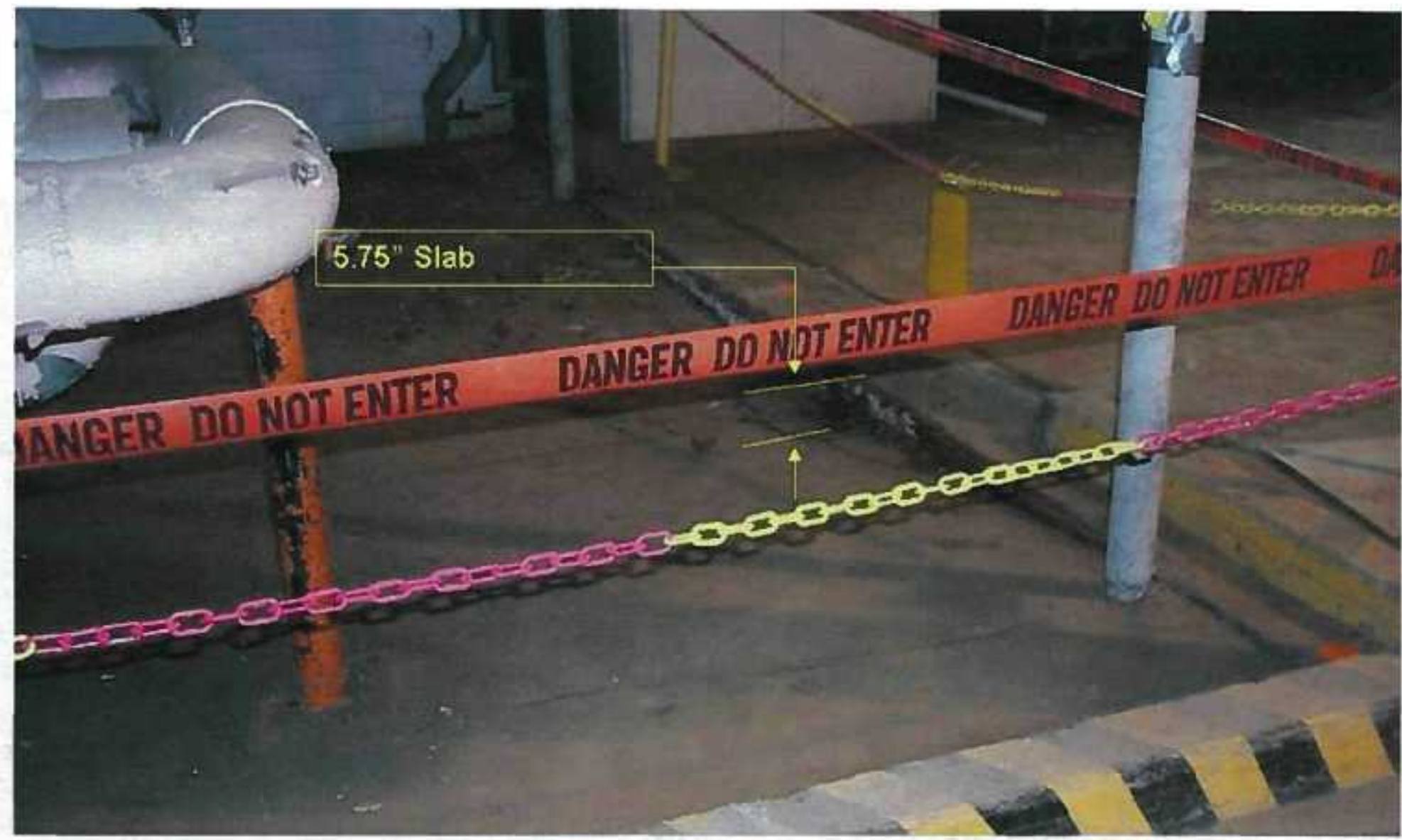

Fig. C-1. View of north edge of damaged slab showing extent of subsidence (looking northwest)* 


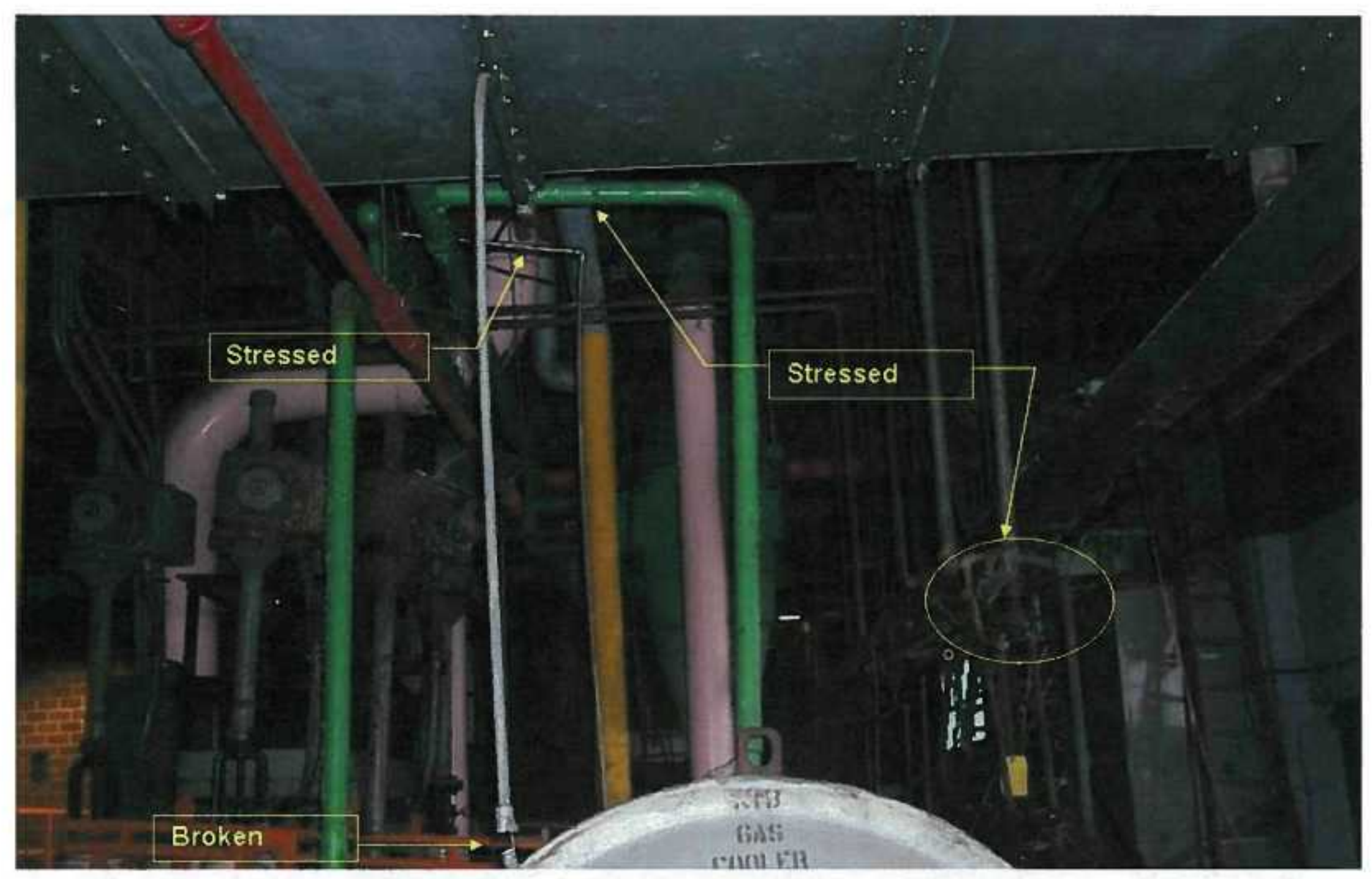

Fig. C-2. View of area above equipment (looking south)*.

•Photo printed from ATI report of August 2003. 


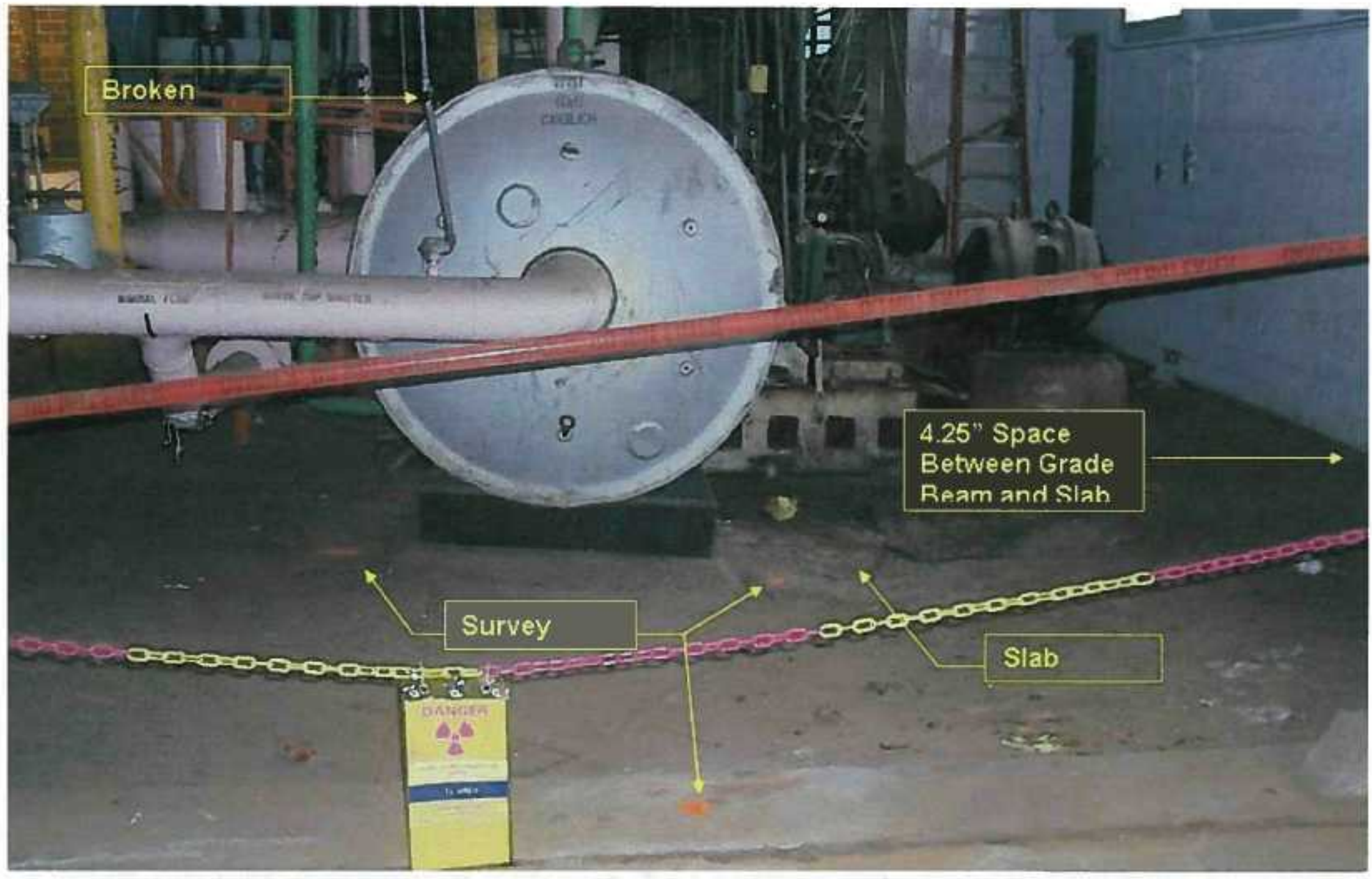

Fig. C-3. View of damaged slab and equipment (looking south)*. 


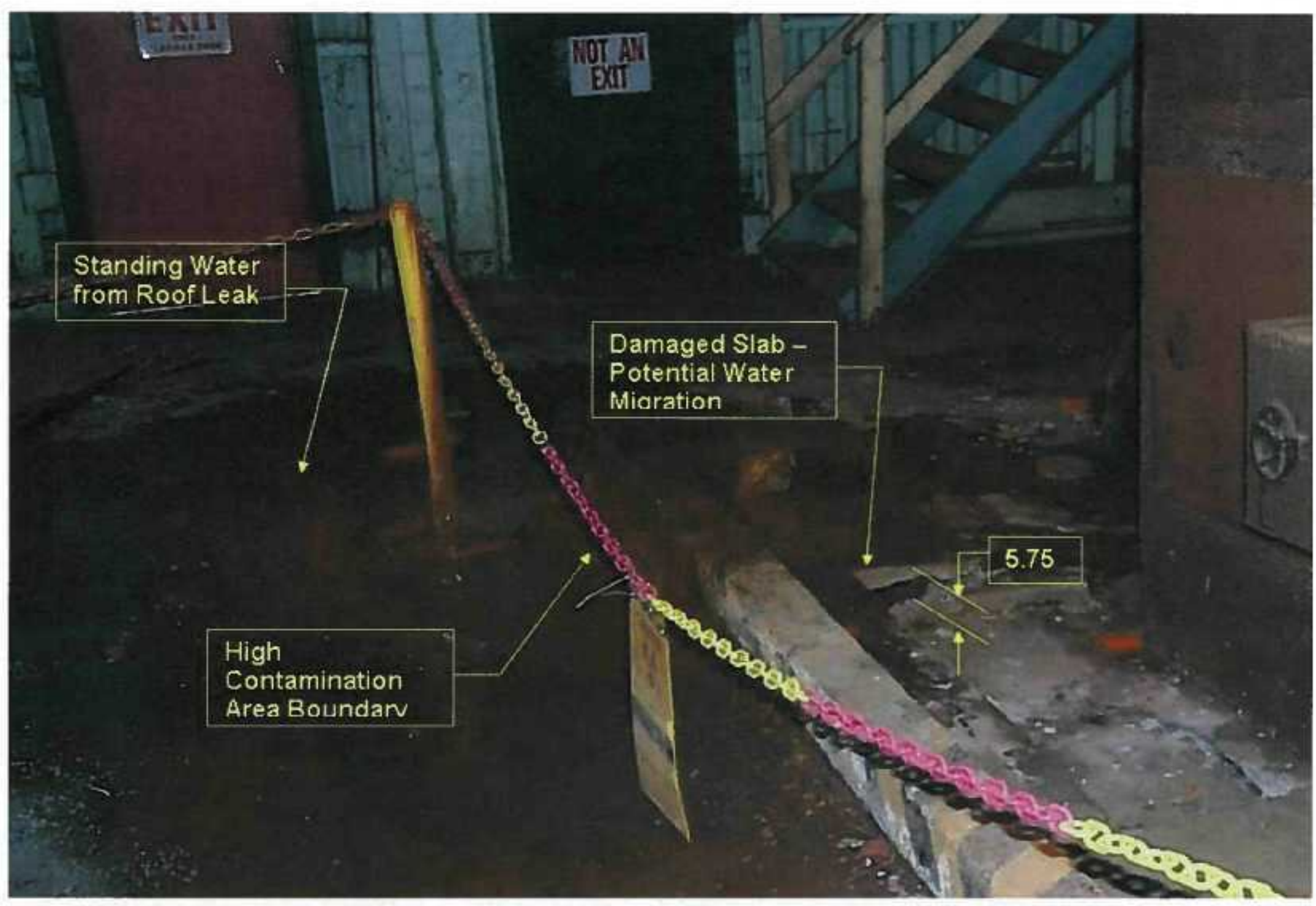

Fig. C-4. View of standing water and damaged slab (looking northwest)*. 


\section{RECORD COPY DISTRIBUTION}

File-DMC-RC 